一般口述発表 


\section{0-1-1 光超音波で見る下肢静脈瘤}

${ }^{1}$ 慶應義塾大学 医学部 外科学 一般 - 消化器, ${ }^{2}$ 慶應義 塾大学 医学部 解剖学教室

$\bigcirc$ 神谷悠紀 ${ }^{1}$, 北川雄光 ${ }^{1}$, 尾原秀明 ${ }^{1}$, 松原健太郎 ${ }^{1}$, 菊池直哉 ${ }^{1}$, 細川恭佑 ${ }^{1}$, 鳥崎友紀子 ${ }^{1}$, 相磯貞和 ${ }^{2}$, 今西宣晶 ${ }^{2}$

【はじめに】現在, 下肢静脈診療において, 主に超音波検査を 用いて下肢静脈瘤の診断を行っているのが現状であるが, 主観 的な評価であり, 客観的に詳細な下肢静脈病変を把握できる非 侵襲的な検査は存在しない。近年, 我が国で開発された光超音 波イメージング装置（PAI: Photoacoustic imaging system）は, 超音波と光による生体計測を融合した新しい非侵襲的画像診断 法として, 悪性腫瘍やリウマチ性疾患, 皮膚疾患など血管に変 化が現れる様々な疾患や, 形成外科, 再生医療など, 血管の評 価が求められる領域で期待されている。我々は, これまでPAI を使用し下肢脈管構造を撮像し, 報告してきた。今回, 下肢末 梢動静脈瘤患者の下肢の微細な画像を得る事ができたため報告 する。

【原理・機器概要】生体を比較的透過しやすい波長帯である近赤 外光を撮像部位にナノ秒パルス照射すると, 生体から弾性波（光 音響波）が発生する。生じた光音響波を複数の超音波センサー で受信し，解析することで 3 次元的な高い分解能の画像を得る ことができる。加えて, 血液中のへモグロビンの吸収が相対的 に高いレーザー波長帯域を使用することにより，光音響波強度 に応じたコントラストの血管画像を非侵襲的に得ることができる。 【方法】下肢静脈瘤患者（n=8）の下肢をPAIによって撮像し, 画像構築を行った。

【結果】平均年齢72.2歳, 男性 3 名, 女性 5 名, CEAP分類では $\mathrm{C} 0 ：$ 名, C1：1名, C2：3名, C3：0名, C4：3名であった。

【結語】これまで下肢末梢動静脈瘤の微細な3次元画像を得るこ とが出来たモダリティはなく, 下肢静脈瘤の新たな分類や治療 法を開発する上できわめて意義が高いと考える。さらに症例を 蓄積し報告したい。

Key words: Photoacoustic Tomography, vein

\section{0-1-2 生体吸収性ポリマーによる薬剤溶出性ステント留 置後冠動脈過収縮反応の抑制効果 一光干渉断層撮影法 （OCT）を用いた臨床的検討一}

東北大学 循環器内科学

○光石清人, 西宮健介, 松本泰治, 渡辺 翼, 土屋 聡, 杉澤 潤, 佐藤公一, 須田 涁, 進藤智彦, 神戸茂雄, 池田尚平, 羽尾清貴, 菊地 翼, 高橋 潤, 下川宏明 【背景】薬剂溶出性ステント (Drug-eluting stents, DES) によ る安定狭心症の治療後も，4割の患者に胸痛が残存することが 知られ，ステント近傍に生じる冠動脈過収縮反応がその原因と して報告されている。我々はブタモデルを用いて, DESを構成 するポリマーに起因するVasa vasorum（VV）増生や外膜の炎 症性変化が, Rho-kinase 活性化を介して冠動脈過収縮反応を惹 起すること, 生体吸収性ポリマーによって冠動脈過収縮反応を 抑制できることを明らかにした。近年, 光干渉断層イメージン
グ（Optical coherence tomography, OCT）によるヒト生体内の VV 画像化手法を確立した。

【目的】生体吸収性ポリマーDES (Bioabsorbable-polymer, BPDES）による冠動脈過収縮反応抑制効果を臨床的に解明すること。 【方法】2013年4月〜2018年12月の間に, BP-DES と従来の恒久 性ポリマーDES（Durable-polymer, DP-DES）を留置された安 定狭心症患者各6例に対して, 治療前・12ケ月後で, アセチルコ リン冠注 $(20 \mu \mathrm{g})$ に対する冠血管反応評価とOCT, 血清学的 検査を反復施行し, 自覚症状の推移を記録した。

【結果】12か月後のアセチルコリンに対する冠動脈収縮反応と $\mathrm{VV}$ 増加量は, BP-DES群で有意に抑制されていた。高感度 CRP はBP-DES群でのみ有意に減少していた。VVと冠動脈収縮反応 の間に正の相関を認めた。治療後の胸痛持続例はDP-DES群で 有意に多かった。

【結論】安定狭心症患者において, BP-DESはDP-DES と比較し て冠動脈過収縮反応の抑制効果を有することを臨床的に明らか にした。

Key words : Drug-eluting stents, Optical coherence tomography

\section{0-1-3 低出カパルス波超音波によるブタ冠動脈過収縮反 応の抑制一新規の低侵襲治療法の開発と分子機構の解明一}

${ }^{1}$ 東北大学 循環器内科, ${ }^{2}$ 国際医療福祉大学塩谷病院循環器 内科, ${ }^{3}$ 東北医科薬科大学医学部生理学, ${ }^{4}$ 国際医療福祉大学 $\bigcirc$ 渡辺 翼 ${ }^{1}$, 松本泰治 ${ }^{2}$, 天水宏和 ${ }^{1}$, 諸沢 薦 $^{1}$,

大山宗馬 ${ }^{1}$, 進藤智彦 ${ }^{1}$, 西宮健介 ${ }^{1}$, 浅香智美 ${ }^{3}$, 林もゆる ${ }^{3}$, 河合佳子 ${ }^{3}$, 下川宏明 ${ }^{1,4}$

背景: 我々は, 冠攣縮の病態形成において冠動脈外膜組織を中 心とした炎症が深く関与していることを報告した。冠動脈外膜 への安全で有効な介入方法はなく, 新たな低侵襲治療の開発が 必要である。我々は近年, 虚血性心疾患や認知症の動物モデル において低出力パルス波超音波（LIPUS）の有効性を示したが, 冠攣縮に対する有効性は不明である。

目的：薬剤溶出性ステント留置後の冠動脈過収縮（冠攣縮）反 応に対するLIPUSの有効性および分子機構の検討。

方法 : 家畜ブタの冠動脈左前下行枝に薬剂溶出性ステントを留 置し, 冠過収縮モデルを作成し, LIPUS群 $(\mathrm{N}=8)$ と sham群 （N=8）に分けた。LIPUS群にはステント近位部，ステント直上, ステント遠位部にそれぞれ20分ずつ，2週間で計6回のLIPUS照 射（32サイクル， $193 \mathrm{~mW} / \mathrm{cm}^{2}$ ) を施した。sham群にはLIPUS 照射をせず，同様の手技を施した。ステント留置の4週間後に， セロトニンを用いて冠動脈過収縮反応を評価し, 免疫組織学的 染色にて冠動脈外膜組織を検討した。

結果：LIPUS群では, sham群に比して, セロトニンに対する 冠動脈過収縮反応が有意に抑制された。また蛍光造影による リンパ管の機能評価において, LIPUS群での機能立進を認め た。組織学的評価ではLIPUS群において, Rho-kinase活性の抑 制や IL-1 $\beta$ 等の炎症の抑制, eNOSの発現増加, リンパ管の増 生, リンパ管新生因子の増加, 脂肪細胞の縮小を認めた。Vasa Vasorum と血管新生因子には有意差を認めなかった。 
考察：LIPUSは冠動脈過収縮反応を抑制し, eNOSやリンパ管 新生因子を介したリンパ管新生の充進・リンパ管機能の充進に よる抗炎症効果を有すると考えられた。

結論：LIPUSは冠攣縮性狭心症の新たな治療法となりうる。

Key words : lymphatic duct, vasospastic angina

\section{0-2-1 冠動脈閉塞を伴わない心筋梗塞 (MINOCA) 患 者に関する検討 -宮城県AMI登録研究-}

${ }^{1}$ 東北大学 循環器内科, ${ }^{2}$ 国際医療福祉大学

$\bigcirc$ 羽尾清貴 ${ }^{1}$, 高橋 潤 ${ }^{1}$, 佐藤公一 ${ }^{1}$, 須田 涁 $^{1}$, 進藤智彦 ${ }^{1}$, 神戸茂雄 ${ }^{1}$, 西宮健介 ${ }^{1}$, 菊地 翼 $^{1}$, 白戸 崇 ${ }^{1}$, 坂田泰彦 ${ }^{1}$, 下川宏明 ${ }^{2}$

【背景】冠動脈閉塞を伴わない心筋梗塞（MINOCA: Myocardial infarction with non-obstructive coronary arteries) は冠動脈 閉塞を伴う心筋梗塞 (MI-CAD: Myocardial infarction with obstructive coronary artery disease) と比較して不明な点が多 い。

【方法】宮城県 $A M I$ 登録研究に2012年〜2017年の間に登録され た急性心筋梗塞（AMI）患者5,753名（男性4,515名/女性 1,238 名）において, MINOCA患者の臨床的特徴と予後を検討した。

【結果】AMI患者の $2.7 \%$ にあたる158名（男性120名，女性38名） がMINOCA と診断された。MINOCA患者はMI-CAD患者と比 較して, 非 ST 上昇型心筋梗塞の割合が高く (45.6\% vs. $21.4 \%$, $\mathrm{P}<0.01$ ), 脂質異常症の合併率が低かったが $(29.7 \%$ vs. $39.6 \%$, $\mathrm{P}<0.01)$, 年齢や性別, 高血圧, 糖尿病, 喫煙の合併率は同等で あった。さらに年代別 4 群 (59歳以下, 60歳代, 70歳代, 80歳 以上）で検討したところ，59歳以下の若年患者でのみ MINOCA 患者は MI-CAD 患者と比較して女性の割合が高く (26.6\% vs. $8.8 \%, \mathrm{P}<0.01)$, 脂質異常症（18.4\% vs. $48.3 \%, \mathrm{P}<0.01 ）$ や糖尿病 (20.4\% vs. 33.3\%, $\mathrm{P}<0.05)$ の合併率は低值であった。院内死亡 率は全症例を対象とすると MINOCA と MI-CAD 患者の間に有意 な差は認められなかったが $(5.7 \%$ vs. $6.9 \%, \mathrm{P}=0.34)$, 年代別解 析では, 70歳以上の高齢患者でMINOCA 患者の院内予後が有意 に良好であった一方で $(4.0 \%$ vs. $10.6 \%, \mathrm{P}<0.05), 70$ 歳未満の若 年患者ではMINOCA患者の院内予後が不良である傾向を認めた (7.2\% vs. $3.6 \%, \mathrm{P}=0.09)$ 。

【結論】本研究の結果から MINOCA は MI-CAD とは異なる特徵 を有し, 特に若年患者において臨床像の違いが顕著であること が示された。

Key words : myocardial infarction, non-obstructive coronary artery

\section{0-2-2 非閉塞性冠動脈疾患患者における冠動脈機能異 常の性差についての検討}

${ }^{1}$ 東北大学 循環器内科, ${ }^{2}$ 国際医療福祉大学大学院 $\bigcirc$ 須田 涁 ${ }^{1}$, 高橋 潤 ${ }^{1}$, 菊地 翼 ${ }^{1}$, 進藤智彦 ${ }^{1}$, 神戸茂雄 ${ }^{1}$, 西宮健介 ${ }^{1}$, 渡辺 翼 $^{1}$, 白戸 崇 $^{1}$, 坂田泰彦 ${ }^{1}$, 下川宏明 ${ }^{1,2}$

【背景】胸通と虚血性心電図変化を有する非閉塞性冠動脈疾患患 者における冠動脈機能異常の性差については未だ不明な点が多い。
【方法と結果】胸痛精查の冠動脈造影において有意狭窄が認めら れずアセチルコリン（ACh）負荷試験が施行された連続187症例 を対象とした（男/女: 113/74, 63.2 12.3 [SD] 歳)。ACh負荷 試験の結果, 冠攣縮陽性 (VSA) 群128例, non-VSA群59例に 分けられたが, 両群間の性別や冠危険因子合併率に差は認めら れなかった。冠微小血管機能については圧温度センサー付きワ イヤーを用いて冠血流予備能 (CFR), 微小血管抵抗指数 (IMR) を全例において測定した。CFRはnon-VSA群とVSA群で有 意差は認めなかったが, IMRはVSA群で有意に高值であった (VSA: $17.5(12.0,25.3)$ vs. non-VSA: $14.7(10.7,17.8), \mathrm{P}=0.02)$ 。 Rho キナーゼ阻害薬である Fasudil を冠動脈内に投与すると, 両 群間におけるIMRの差は消失した（VSA: 15.9 (11.4,21.3）vs. non-VSA: $14.3(10.5,20.3), \mathrm{P}=0.38)$ 。さらにVSA群において冠 微小血管機能の性差を検討すると, IMRは男女間で差は認めら れないものの,CFRは男性に比べ女性において有意に低值を示し た（男: $2.74(1.89,3.66)$ vs. 女: $2.22(1.55,2.91), \mathrm{P}=0.02)$ 。さらに Fasudil投与によりCFRは男女間において同等となった（男: 2.95 $(2.00,4.39)$ vs. 女: $2.51(1.49,3.95, \mathrm{P}=0.27)$ 。

【結論】VSA患者ではRhoキナーゼ依存性の機序により CFR 低 下が引き起こされ, 特に男性に比べ女性において顕著である可 能性が示唆された。

Key words : Vasospastic angina, Rho-kinase

\section{0-2-3 再発した急性冠症候群患者の特徵と二次予防}

${ }^{1}$ 日本医科大学付属病院 心臓血管集中治療科, ${ }^{2}$ 日本医科 大学 循環器内科

$\bigcirc 太$ 良修平 ${ }^{1}$, 石原 翔 $^{1}$, 山田健太 ${ }^{1}$, 岡英一郎 ${ }^{1}$, 杉崎陽一郎 ${ }^{1}$, 塩村玲子 ${ }^{1}$, 松田淳也 ${ }^{1}$, 中田 淳 $^{1}$, 山本 剛 ${ }^{1}$, 清水 涉 $^{2}$

【目的】急性冠症候群 (ACS) の再発は, 冠動脈疾患患者の予後 を悪化させるため二次予防が重要である。本研究の目的は, 再 発ACS 患者の特徵を初発 ACS 患者と比較し明らかにするととも に, 二次予防としてガイドラインで推奨する目標值をどの程度 達成していたかを調査することである。

【方法】ACS患者214名 (ST 上昇型心筋梗塞: 126名, 非 ST上 昇型心筋梗塞: 61 名, 不安定狭心症: 27 名）を, 初発 ACS 群 $(\mathrm{n}=182)$ と再発ACS群 $(\mathrm{n}=32)$ に分類した。

【結果】再発ACS 群は初発ACS 群と比較して, 高齢 $(68.8 \pm$ 13.4 vs $76.8 \pm 10.8$ 歳, $\mathrm{p}=0.002)$ で糖尿病の罹患率が高く $(36.8$ vs $65.6 \%, \mathrm{p}=0.003)$, ST 上昇型心筋梗塞の割合が低かった $(62.6$ vs $37.5 \%, p=0.011)$ 。再発ACS群において, ガイドラインで推 奨されている $\mathrm{HbAlc}<7.0 \%$ の達成率は $67 \%$ に対してLDLコレス テロール $<70 \mathrm{mg} / \mathrm{dl}$ の達成率は $28 \%$ だった。また, これら冠危 険因子の管理目標達成に加えて, 至適薬物治療 (ACE 阻害薬/ $\mathrm{ARB}, \quad \beta$ ブロッカー, 抗血小板薬, それぞれの内服の有無), 契 煙の有無による合計6項目による総合評価で, 最適な二次予防が 行われていた再発 ACS患者の割合は, $12.5 \%$ と低值だった。続 いて退院後の心血管イベント発生率を 2 群間で比較したところ 再発ACS群で有意に高く（観察期間: 中央值375日, log rank: $\mathrm{p}=0.004), \mathrm{ACS}$ 再発はその後の心血管イベントの独立した危 
険因子だった（ハザード比:2.45, $\mathrm{p}=0.025 ） 。$

【結論】再発ACS患者は, 特に脂質管理において十分な二次予 防が行われておらず，その後の心血管イベント発生も高率であっ た。

Key words : acute coronary syndrome, secondary prevention

\section{0-2-4 CABGのグラフトに使用した内胸動脈と同側の AVFの過剩血流により、内胸動眽の高度盗血現象 (逆流) を認めた 1 例}

牧港中央病院 心臓血管外科

$\bigcirc$ 毛利教生, 上江洲徹, 杉山博信, 洲鎌盛一

はじめに透析患者の $\mathrm{CABG}$ 後に特有の問題点として, 透析中に シャント側の内胸動脈グラフトで盗血現象が起こる可能性が指 摘されている。Coronary-subclavian syndrome (CSSS) は全 身性スチールの一つであり, AVFの過剩血流は全身性のスチー ル症候群を起こす可能性が高いと考えられる。(AVFの過剩血 流は $1500-2000 \mathrm{ml} / \mathrm{min}$ 以上と定義されている。）今回, 我々は, 過剩血流による，CSSSを経験したので報告する症例67歳,男性 主訴:胸部圧迫感透析歴:2年現病歴:透析時に血圧低下, また, 最近, 非透析時にも胸部圧迫感を自覚。左内シャントの過剩血 流を認めた。既往歴:3年前にCABG（LITA-LAD） 入院後経過: 過剩血流による, CSSSを疑い, 血流抑制術を行うが, 血流量は, 3009ml/min から $1975 \mathrm{ml} / \mathrm{min}$ までしか, 低下せず, 症状も改善 を得られなかった。冠動脈造影を行ったところ, 左冠動脈造影 の際, 逆行性にI T Aグラフトが造影され，また， I T Aグラフ 卜を撮影した際は，スチールされて，グラフトは造影不可能で あった。AVFの閉鎖を施行し，その後から症状は消失した。術 後, 冠動脈造影で, 左冠動脈造影でITAグラフトは造影されな くなり, ITAグラフトは直接造影可能となった。考察透析患者 の AVFと同側のITAgraftを使用した場合のCSSSに関して，エ コーでITAgraftの血流を評価し，透析時に同側のITAgraftの 血流量低下を示した論文はある。しかし, 今回の症例のように, CSSSとして, CAGで明らかな ITAgraftの逆流が確認できてい る症例は非常に稀である。また,一様に, 同側にAVFにより, CSSSが起こるわけではなく, 今回のような過剩血流がリスクに なることを，この症例は示唆していると考えられる。

Key words : CSSS, AVF

\section{0-3-1 IgG4 関連心疾患 (心膜, 冠動脈, 腫瘍) の治療指針} ${ }^{1}$ 国立病院機構 金沢医療センター 心臓血管外科, ${ }^{2}$ 金沢 大学医薬保健研究域保健学系病態検査学

$\bigcirc$ 松本 康 $^{1}$, 笠島里美 ${ }^{2}$, 笠島史成 ${ }^{1}$, 池田知歌子 ${ }^{1}$

【目的】最近注目の IgG4関連疾患（IgG4-RD）は, IgG4陽性形 質細胞浸潤, 線維増生を特徵とする指定難病であり, 我々は血 管系における IgG4-RD を報告してきた。今回, IgG4-RDの心臓 病変に注目し, 収縮性心膜炎, 冠動脈瘤, 心腔内腫瘍を生じた IgG4関連心疾患 (IgG4-CD) に対して外科的治療やステロイド 投与を行い，遠隔成績から治療方針を考察したので報告する。 【対象と方法】IgG4-CD 12症例を対象とした。平均年齢70.0歳, 男女比 $9: 3$, 血清 $\operatorname{IgG} 4$ 值は平均 $636.5 \mathrm{mg} / \mathrm{dl}$ 。診断基準での確診
は8症例であった。治療として, 収縮性心膜炎の2例, 心腔内腫 瘍の1例には心膜切除, 腫瘍切除を施行した。冠動脈瘤の9例に は, 瘤切除および冠動脈バイパス術を 1 例に, 外科治療後に低用 量ステロイド（LDS）治療併用を1例に, 高容量ステロイド治療 （HDS）を2例に，LDSを5例にそれぞれ行い，その予後をもとに 考察した。

【結果】収縮性心膜炎, 心沿内腫瘍の3例は, 術後IgG4值が正常 化し，3年の経過で再発を認めていない。冠動脈瘤症例でHDS を行った2例では破裂による突然死を認めた。瘤切除・冠動脈バ イパス術の1例と外科治療にLDS 併用症例では IgG4值の著明な 低下を得，13年の経過で再燃を認めていない。LDSのみを行っ た5例でも IgG4值の低下を認め10年の経過で全例生存し, 経過 観察中である。

【結語】IgG4-CD に対する外科的治療は奏効性が高く，有効な治 療と考えられた。一方, 冠動脈瘤に対するHDSについては, 瘤 の破裂頻度が高く, ステロイドによる急速な外膜菲薄化の可能 性があり，慎重に行うべきと考えられた。IgG4-RDに対し，ス テロイドを使用する際は, CT所見の変化, 体格や疾患活動性, 血清IgG4值に合わせたLDSが推奨される。

Key words : IgG4, Cardiac disease

\section{0-3-2 高コレステロール血症性弁膜症の臨床と病理}

イムス札幌内科リハビリテーション病院

河口明人

目的 家族性高コレステロール血症 (FH) ホモ接合体患者にお ける血管合併症の臨床的実態を精査することによって，コレス テロールによる血管合併症の特徵を明らかにする。方法 初診時 25歳未満の FHホモ接合7名（5～24歳）の臨床所見を，心臟超音 波法, 血管造影検查 (CAG, AOG) で精查し, 弁置換術 (AVR) を受けた患者および突然死したへテロ接合体FH患者の病理所 見と比較した。結果 $\mathrm{FH} モ$ 接合体患者7名のうち6名に大動脈 弁逆流が存在し，4名が大動脈弁狭窄症（AS）を呈し，そのう ちの3名が弁口面積 $1.0 \mathrm{~cm}^{2}$ 未満であり, その後の LDL aphersis 治療でも進展を抑止できず，AVRを受けた。大動脈弁尖の病理 所見は, 左心室側には線維性変化, 大動脈側では石灰化を含む necrotic coreによる弁尖破壊像を呈し, 免疫染色ではapoBが確 認された。アテローム性病変は, 弁尖からヴァルサルバ洞直上 の sinotubular ridgeおよび上行大動脈に進展し, 冠動脈では, とくに入口部病変が特徵的であり，9歳女児はすでに右冠動脈入 口部で閉塞していた。周術期死亡例では, 僧帽弁尖にもコレス テロールの浸潤が確認された。一方突然死したFHへテロ患者の 大動脈弁尖は癒合しており, 重篤なASが疑われた。コレステロー ルによる血管障害をもっとも純粋な形で評価できる FH ホモ接合 体患者の病変は, 大動脈基部に集中し, 冠動脈 (入口部), 大動 脈弁, 上行大動脈, 僧帽弁であり, これらのうちもっとも重篤 で致死的な合併症はASである。結論 高コレステロール血症に よる血管障害は左心室駆出近位部に集中的に発生し, 大動脈弁 狭窄症はとくにFHホモ接合体患者の予後を決定する最も重篤な 合併症であり，「高コレステロール血症性弁膜症」が存在する。 Key words : Familial Hypercholesterolemia, 
Hypercholesterolemic Valvulopathy

\section{0-3-3 高安病に併存した大動脈弁閉鎖不全に対する当 院の治療方針}

山梨大学 第 2 外科

○榊原賢士, 中島博之, 荻原千恵, 四方大地, 吉田幸代, 河合幸史, 白岩 聡, 本田義博, 村田眞哉, 加賀重亜喜, 鈴木章司

（はじめに）今回，当院で高安病に合併した大動脈弁閉鎖不全に 対して大動脈弁置換術を施行した症例の検討を行った。

（対象）高安病に対する大動脈弁置換術を施行した症例は2002年 から2020年までに3例，平均年齢46歳（39歳～53歳）全員女性で あった。当院の方針として可能な限り術前ステロイドを減量し, 造影 CT で送血部位の確認, 血管病変の診断を行って手術を施行 した。

(結果) 症例 $1 ： 39$ 歳女性。腎動脈, 腹部大動脈狭窄, 胸部大動 脈の石灰化を指摘され高安病と診断された。労作時呼吸困難の ため精査したところRCA \#190\%, severe ARを指摘されAVR, CABGを施行した。上行大動脈の性状不良であったため送血は 大腿動脈から行った。症例 $2: 53$ 歳女性。severe AR，MRに よる心不全増悪のため準緊急でAVR，MVRを施行した。上行 大動脈-胸部下行大動脈にかけて石灰化強く, 送血は大腿動脈か ら行った。症例 $3: 46$ 歳女性。労作時呼吸困難の精査にて AR, MR と診断。手術は AVR, MVRを施行した。左総頸動脈, 両 側鎖骨下動脈は閉塞，上行大動脈は石灰化を認めたが一部良好 な部位があり上行大動脈から送血を行った。待機手術の 2 例は経 過順調であったが, 準緊急手術の1例は敗血症のため死亡した。 (考察，まとめ） 3 例とも上行大動脈の変性をみとめ, 送血部位, 大動脈切開部位に注意を要し CT所見が重要であった。死亡した 準緊急症例は，高安病を併存していたため内科管理が長くなり 手術のタイミングが遅くなったと考えられる。長期予後に関して, 待機手術の 2 例は退院後，順調に経過し人工弁逸脱なく経過して いるが炎症の再燃による人工弁逸脱などの可能性があり今後も 注意深いフォローが必要である。

Key words: AR, takayasu disease

\section{0-3-4 補助循環用ポンプカテーテルIMPELLA ${ }^{\mathrm{TM}}$ の使用 経験と展望}

${ }^{1}$ 東北大学 循環器内科学, ${ }^{2}$ 東北大学 心臓血管外科学 $\bigcirc$ 神戸茂雄 ${ }^{1}$, 菊地 翼 $^{1}$, 高橋 潤 $^{1}$, 進藤智彦 ${ }^{1}$, 西宮健介 ${ }^{1}$, 白戸 崇 ${ }^{1}$, 坂田泰彦 ${ }^{1}$, 齋木佳克 ${ }^{2}$, 下川宏明 ${ }^{1}$ 補助循環用ポンプカテーテル（商品名 IMPELLA ${ }^{\mathrm{TM}}$ ) とは, 従来 治療抵抗性の心原性ショックに対して, 経皮的に左室内へ挿入・ 留置し, 左室内から直接脱血して上行大動脈へ順行性に送血す ることで体循環を補助するカテーテル式の体内式軸流ポンプ装 置である。当院では2018年度より IMPELLA ${ }^{\mathrm{TM}} 2.5$ ならびに 5.0 が，2019年秋より IMPELLA ${ }^{\mathrm{TM}}$ CPが使用可能になった。これま でに9例（劇症型心筋炎の4例，急性心筋梗塞による心原性ショッ クの 2 例，左主幹部への経皮的冠動脈インターベンションの1例, 拡張型心筋症の 1 例, 虚血性心筋症背景の心室頻拍ストームの 1 例,
平均年齢52歳, 男女比6:3) に延べ11回使用した。IMPELLA ${ }^{\mathrm{TM}}$ ポンプカテーテル使用回数の内訳は, IMPELLA ${ }^{\mathrm{TM}} 2.5$ を回, IMPELLA $^{\mathrm{TM}} \mathrm{CP} 1$ 回, IMPELLA ${ }^{\mathrm{TM}} 5.0$ を回であった。アク セス部位に関しては, IMPELLA ${ }^{\mathrm{TM}} 2.5$ ならび CPは大腿動脈 から経皮的穿刺法で留置し, IMPELLA ${ }^{\mathrm{TM}} 5.0$ は左鎖骨下動脈か らカットダウン法で人工血管を建てて留置した。半数以上は経 皮的心肺補助装置との併用である通称ECPELLA管理を要する 超重症例であったが, 全例で心原性ショックからの回復を認め, 30日生存率は $67 \%$ であった。主な合併症として, 溶血による急 性腎傷害, 下肢阻血, 插入部出血を認めた。これら初期症例を 総括し, 低侵襲かつ迅速に導入可能な補助循環装置としての今 後の展望を考察する。

Key words: Impella ${ }^{\mathrm{TM}}$, mechanical circulatory support

\section{0-3-5＼cjkstart血管治療後に発症したコレステロール塞栓症の 3 例} ${ }^{1}$ 静岡赤十字病院 心臓外科, ${ }^{2}$ 静岡赤十字病院 血管外科

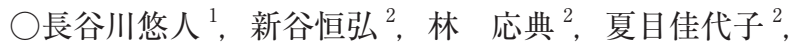
大倉一宏 ${ }^{1}$

【緒言】コレステロール塞栓症（CCE）は心臟血管手術やカテー テル操作, 抗凝固療法などを契機に大動脈の邭状硬化巣破綻に よりコレステロール結晶が飛散し全身の細動脈を閉塞して生じ る肉芽腫性血管炎である。当院で施行した血管治療後に発症し たCCEの3症例を経験し，若干の知見を得たので報告する。

【症例】症例1.64歳男性, 腹部大動脈瘤 (AAA) に対して開腹 人工血管置換術を施行。術前よりGrade4のCKDがあり術直後 からCHDFを施行，術後3日目より透析導入した。術後31日目よ り38度台の発熱, CRP ・好酸球上昇を認めCCEと判断した。ア セトアミノフェン内服にて解熱が得られ, 炎症反応は自然軽快 した。症例2. 66歳男性, AAAに対して低心機能を理由にステ ントグラフト内挿術を施行。術後10日目から腎機能低下, 術後 16日目に両側第5趾に有痛性紫斑出現, 好酸球の増加を認めCCE と判断した。腎臓癌にて右腎臓摘出予定もあるため透析導入と し，足趾紫斑は限局的だが壊死に至ったため断端形成を施行した。 症例3. 67歳男性, 右第5趾潰瘍形成に対して血管内治療を施行 したが創傷治癒得られず, 発熱持続するために右大腿切断を施 行した。切断後も38度台の発熱が持続し, 腎機能の急激な増悪 を認めた。高度の大動脈の桞状硬化もあり, 血液検査で好酸球 上昇を認めCCEと判断L PSL内服を開始。腎機能は改善し透析 導入は回避でき解熱も得られた。

【考察】高度の大動脈の㑛状硬化を有する患者に対する心臓血 管手術はCCE発症の危険因子である。CCEに対する有効な予防 方法や確立した治療手段は存在しないが, 臨床症状から早期に CCEを想定，診断することが重要であると考えられる。

Key words : Cholesterol Crystal Embolization, CCE 


\section{0-4-1 自己拡張型弁を留置された冠動眽疾患に対する 経皮的冠動脈インターベンション}

東北大学 循環器内科学

○菊地 翼, 松本泰治, 土屋 聡, 進藤智彦, 神戸茂雄, 西宮健介, 白戸 崇, 高橋 潤, 下川宏明

大動脈弁狭窄症（AS）に対する経カテーテル大動脈弁置換術 （TAVI）の普及は近年目覚ましいものがある。AS患者は冠動 脈疾患の合併が多く, TAVI後に急性冠症候群 (ACS) を発症し, 経皮的冠動脈インターベンション（PCI）を必要とする症例が 今後増加すると考えられる。自己拡張型TAVI弁は有効弁口面 積の獲得に優れる一方, 冠動脈入口部がフレームで覆われるた め冠動脈へのカテーテル挿入が困難となる。今回我々はTAVI 後にACSを発症した2症例のPCIについて報告する。症例 1 : $26 \mathrm{~mm}$ 弁が留置され，19力月後に ACSを発症。左回旋枝にステ ント持ち込み困難のためPOBAのみで終了。この際，右冠動脈 にはカテーテル挿入不可であった。その7カ月後にACSを再発。 延長カテーテルを併用しPOBA 再狭窄部へのステント留置に成 功。その後も胸痛が改善しないため, 4Fr JR4で右冠動脈の造影 を試み, 狭窄病変を確認した。診断カテからガイドワイヤーを 末梢まで挿入し，延長ワイヤーを用いPCI用カテーテルに交換 しステントを留置した。症例 $2: 29 \mathrm{~mm}$ 弁が留置され, 9力月後 にACSを発症。左主幹部遠位部から前下行枝と回旋枝入口部に 連続する狭窄を認めた。TAVI後に施行していた心電図同期 CT を参考に，IR1.0ガイドカテを用いてワイヤーを左冠動脈に挿入。 カテーテル自体の挿入は困難であったが, 延長カテーテルを併 用し前下行枝と回旋枝の入口部両者にPCIを施行した。自己拡 張型弁留置後のPCIの際には弁形状の理解と様々な手技上の工 夫が必要であり, 特に冠動脈入口部とTAVI弁フレームの位置 関係を把握するためのCT撮影は有用である。

Key words : PCI, TAVI

\section{0-4-2 肺血管拡張薬開始後に左心不全を発症した膠原 病性肺高血圧症の一例}

岩手県立中央病院 循環器内科

$\bigcirc$ 三浦正暢, 薄田 海, 内村久美, 山田祐資, 安達 歩, 畠山翔翼, 山田魁人, 加賀谷裕太, 齊藤大樹, 佐藤謙二郎, 金澤正範，近藤正輝，遠藤秀晃，中村明浩

【症例】60歳代女性。

【主訴】呼吸苦。

【既往歴】A病院にて拡張型心筋症と診断され, ビソプロロール, トラセミドを内服。心房細動, 心原性脳梗塞によりアピキサバン, ジゴキシンを内服。食道狭窄のため腸癭造設。

【現病歴】2020年3月X日より労作時の呼吸苦を自覚, 3月 X+1日 になっても症状の改善がないため当院に救急搬送された。

【現症】血圧90/52mmHg, 脈拍 $127 /$ 分, SpO2 87\%（室内気）, 心音 gyallop rhythm, 四肢冷感著明, 浮腫なし。

【検查所見】血液検查：BUN $51.5 \mathrm{mg} / \mathrm{dL} ，$ Cre $1.19 \mathrm{mg} / \mathrm{dL} ， \mathrm{Na}$ $124.1 \mathrm{mEq} / \mathrm{L}, \quad B N P 1164.6 \mathrm{pg} / \mathrm{dL}$, 抗 U1-RNP 抗体陽性。心電 図：頻脈性心房細動, 心拍数139/分, 右軸偏位。心臓超音波検 查：左室駆出率53\%, MR III, D shapeあり, TR III, TRPG
$65.5 \mathrm{mmHg}$ 。

【経過】検査所見より混合性結合組織病を基礎にした肺高血圧 症が疑われた。カテコラミン等の投与により状態が安定化した 後施行した心臓カテーテル検査では，コントロールにおいて肺 高血圧症を認めなかったが, 生理食塩水負荷試験 $(500 \mathrm{ml} / 5$ 分) では，前毛細血管性肺高血圧症が顕在化した（平均肺動脈圧 $35 \mathrm{mmHg}$, 肺動脈楔入圧 $10 \mathrm{mmHg}$ )。膠原病に対して免疫抑制薬 を検討したが，フレイリティが高く感染等のリスクが高いと判 断され見送られた。そのため, マシテンタン $10 \mathrm{mg} /$ 日, セレキ シパグ $0.6 \mathrm{mg}$ /日を順次開始して経過を見たところ TRPGの低下， BNPの改善を認め, NYHA class IIまで改善し退院した。しかし, 退院後まもなく左心不全が増悪したため再入院となった。

【結語】今回われわれは, 拡張型心筋症の既往のある膠原病性肺 高血圧症に対して肺血管拡張薬を導入後, 左心不全を増悪した 貴重な一例を経験したので報告する。

Key words : pulmonary hypertension, heart failure

\section{0-4-3 補助循環下での化学療法で救命し得た胃癌によ る顕微鏡的微小肺動脈腫瘍塞栓の一例}

東北大学 循環器内科学

$\bigcirc$ 福井重文, 照井洋輔, 杉村宏一郎, 建部俊介, 山本沙織, 鈴木秀明, 矢尾板信裕, 菊地順裕, 佐藤 遥, 紺野 亮, 下川宏明

症例は40歳女性。進行性の息切れの精査目的に近医入院となり, 肺静脈閉塞性疾患の疑いで当科転院となった。血液検査で CEA $24 \mathrm{ng} / \mathrm{mL}$ と上昇し, 肺血流シンチで肺動脈末梢の胸膜直下に顕 微鏡的微小肺動脈腫瘍塞栓（PTTM）に特徵的な小多発欠損像 を認めた。右心カテーテル検査では重症の前毛細血管性肺高血 圧症（平均肺動脈圧 $50 \mathrm{mmHg}$ ）を呈し, PET-CTで左側卵巣に 異常集積を認めた。第3病日に血行動態が破綻しVA-ECMOが装 着となったが, 卵巣癌によるPTTM疑いで化学療法を開始した所, 以後週単位での肺血行動態の改善を認め, 第10病日に補助循環 を離脱し得た。2回目の胃生検で印環細胞癌の所見であり，卵巣 転移を伴う進行胃癌によるPTTM と診断した。右心不全症状は 安定し (NYHA2度), 外来にて肺血管拡張薬及び抗癌剂による 治療継続をしたが, 発症から8ヶ月後に癌の進展により永眠され た。進行胃癌・転移性卵巣腫瘍によるPTTMに対し, 体外補助 循環使用下で，これまで有効との症例報告が散見されるイマチ ニブを使用せずに，化学療法単独により救命し得た 1 例を経験 したため報告する。

Key words : pulmonary hypertension, pulmonary embolism

\section{0-4-4 全周性壁運動低下を認めたR-IIIc型の単冠動眽症 の一例}

仙台市立病院

$\bigcirc$ 三引義明，倉島真一，青木恒介，佐藤英二，山科順裕， 石田明彦, 八木哲夫

【背景】単冠動脈は比較的稀な先天性冠動脈奇形（Yamanaka ら の報告では $0.044 \%$ ）であり，他の心奇形合併がないものは予後 良好といわれてきたが，近年重篤な心疾患合併の報告がなされ 
ている。

【症例】60歳台前半の女性。

【既往歴】50歳糖尿病（未治療 $\mathrm{HbAlc} 11.1 \mathrm{mg} / \mathrm{dl}$ ), 脂質異常症。 52 歳掌蹠膿疮症。

【現病歴】2020年春に咳嗽，呼吸苦のため救急搬送され，肺炎を 合併したうっ血性心不全として入院した。心エコーで全周性壁 運動低下を認め, EF $26.6 \%$ と低下していた。心不全改善後に施 行した冠動脈造影および冠動脈 CTでは, 右冠動脈優位で, 左冠 動脈は右冠尖の右冠動脈入口部のわずかに頭側から起始しており, 左前下行枝は肺動脈前面を走行し, 右室枝を分枝した後に前壁 を還流していた。回旋枝は肺動脈と大動脈の間を走行し, 中隔 枝を分枝した後に房室間溝を走行しており，Lipton分類R-III， Yamanaka分類でR-IIIcの単冠動脈症と診断した。いずれの冠動 脈にも有意狭窄は認めなかった。左室生検では一部に収縮帯壊死, 間質の軽度浮腫を伴った繊維化を認め, 虚血性変化が示唆された。 しかしMRIの遅延造影像や, 運動負荷心電図での胸部症状や心 電図変化は認めなかった。

【考察】Shiraniらは単冠動脈症の15\%には冠動脈硬化がなくて も心筋虚血を認めたと報告している。しかし本症例では冠動脈 支配領域に一致しない全周性左室壁運動低下を認めており, 単 冠動脈に由来する心筋虚血のみではなく, 糖尿病性心筋症によ る心機能低下も合併していると考えられた。厳重な血糖コント ロールを含めた内科的心不全治療を行った。

【結語】未治療糖尿病を合併した単冠動脈症に, 心機能低下をき たした一例を報告する。

Key words : single coronary artery, specific cardiomyopathy

\section{0-5-1 跛行肢に対する 2 週間入院監視下運動療法後の 6 ヶ月目の評価}

${ }^{1}$ イムス三芳総合病院 外科, ${ }^{2}$ イムス三芳総合病院 リハ ビリテーション科

$\bigcirc$ 内村智生 ${ }^{1}$, 池田豊秀 ${ }^{1}$, 福田千文 ${ }^{1}$, 瀬尾克久 ${ }^{2}$, 田中成周 ${ }^{2}$, 鈴木啓汰 ${ }^{2}$, 千喜良佳織 ${ }^{2}$, 木村優大 ${ }^{2}$, 松谷 実 $^{2}$

【目的】間歇性跛行（IC）に対する運動療法が推奨されて20年以 上経過したが, 未だ普及していない。2週間の入院監視下運動療 法を施行し，退院後の6ヶ月目までの有用性を検討した。

【方法】2016年1月から2020年5月までICを認める ABI 1.0未満 のPAD 患者に対し, 2 週間の入院によるトレッドミルを用いた 監視下運動療法を行った。トレッドミルは2.4 $3.6 \mathrm{~km} / \mathrm{h}$, 勾配 $12 \%$ で行い, 跛行出現距離 (ICD) と絶対跛行距離 (ACD) は $3.6 \mathrm{~km} / \mathrm{h}$ または $2.4 \mathrm{~km} / \mathrm{h}$ で測定し, 上限を $1500 \mathrm{~m}$ とした。両下 肢に病変を有する場合は, IC の出現する一側のみを評価した。 退院後は当院オリジナルの指導パンフレットや自己申告チェッ クリストを用いた外来通院を1ヶ月に1回とし，3ヶ月目，6ヶ月 目のICD，ACDの測定を行った。

【結果】男性 19 名, 女性 3 名。平均年齢は $73.0 \pm 5.9$ 歳。 $3.6 \mathrm{~km} / \mathrm{h}$ 群 は13名で, 開始時 ICD $361.9 \pm 424.3 \mathrm{~m}, \mathrm{ACD} 796.5 \pm 532.8 \mathrm{~m}$, 退 院時 ICD $676.2 \pm 517.2 \mathrm{~m}, \mathrm{ACD} 1113.1 \pm 491.7 \mathrm{~m}, 3$ 个月目 ICD $716.9 \pm 534.1 \mathrm{~m}, \mathrm{ACD} 1143.8 \pm 458.0 \mathrm{~m}, 6$ ケ月目 $\mathrm{ICD} 863.8 \pm$

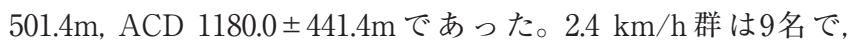
開始時 ICD $287.8 \pm 241.5 \mathrm{~m}, \mathrm{ACD} 621.1 \pm 374.7 \mathrm{~m}$, 退院時 ICD $858.9 \pm 568.4 \mathrm{~m}, \mathrm{ACD} 937.8 \pm 496.3 \mathrm{~m}$, 3ヶ月目 $\mathrm{ICD} 1014.4 \pm$ $517.0 \mathrm{~m}, \mathrm{ACD} 1026.7 \pm 504.1 \mathrm{~m}, 6$ ケ月目 $\mathrm{ICD} 965.6 \pm 565.1 \mathrm{~m}$,

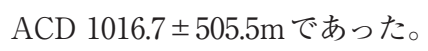

【結語】2週間入院監視下運動療法は, ICD, ACDの改善を認め た。さらに退院後の当院オリジナルの指導パンフレットや自己 申告チェックリストを用いた非監視下運動療法6ヶ月後は退院時 と比較し ICD, ACDの改善または維持が可能であり，3〜6ヶ月 の週3回監視下運動療法に代わる方法であると示唆された。

Key words : Peripheral Arterial Disease, Exercise Therapy

\section{0-5-2 超音波を用いた末梢動脈疾患における虚血肢の 骨格筋組成の評価と検討}

${ }^{1}$ 日本保健医療大学 理学療法学科, ${ }^{2}$ 福山循環器病院 リ ハビリテーション課, 3 福山循環器病院＼cjkstart循環器内科 $\bigcirc$ 湯口 聡 ${ }^{1}$, 越智裕介 ${ }^{2}$, 相方由香理 ${ }^{2}$, 井手迫光弘 ${ }^{2}$, 前田紫乃 ${ }^{2}$, 旭 竜馬 ${ }^{1}$, 谷口将人 ${ }^{3}$

【目的】PADの虚血肢において, 腓腹筋の筋組成を超音波によっ て評価し健常者のものと比較した。

【方法】対象は血行再建術を目的に入院したFontaine2度のPAD 症例 4名6肢（年齢中央值76.5歳, 男性4名, ABI 中央值0.75）と健 常男性（control）42名42肢（年齢中央值75.0歳）である。対象 の6肢は血行再建術対象の下肢とした。PADの超音波（ビュー ズアイ; 酒井医療製) は手術前日に行い, 皮下脂肪厚, 腓腹筋肥厚, 筋輝度および補正筋輝度を測定した。超音波は端坐位の状態で 下腿最大周径部における左右の腓腹筋内側頭を測定した。また, 同日に基本情報および身体機能として握力, 通常歩行速度, 体 組成計により筋骨格筋指数も測定した。さらに, 最大歩行距離 を手術前後に測定した。controlにおける超音波は2019年4月〜 12月に同様の方法で行った。本研究は福山循環器病院および日 本保健医療大学倫理委員会において承認を得ている。

【結果】超音波の皮下脂肪厚 $(\mathrm{m} \mathrm{m})$, 腓腹筋肥厚 $(\mathrm{m} \mathrm{m})$, 笳輝 度および補正筋輝度の中央值は control と PADにおいてそれぞれ， 2.6vs3.8 ( $\mathrm{p}<0.02), 13.3 \mathrm{vs} 10.3(\mathrm{p}<0.01), 74.2 \mathrm{vs} 105.7(\mathrm{p}<0.01)$,

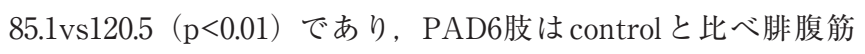
肥厚は少なく, 筋輝度は高值であった。また, $\mathrm{PAD}$ 各4例の検 討では, 最大歩行距離が手術前に長かった症例や術後に大きく 改善した症例は筋輝度が低值で, 筋力や骨格筋量が多い傾向が あった。

【結語】超音波による筋輝度は骨格筋における筋内脂肪の割合を 反映するとされている。超音波による筋肥厚や筋輝度は, $\mathrm{PAD}$ において虚血に由来する骨格筋組成の変化を反映している可能 性がある。今後症例を増やし歩行距離との関連について検討を 進める必要がある。

Key words : PAD, Ultrasonography, gastrocnemius, echointensity 


\section{0-5-3 重症虚血肢患者でのPerfusion Indexによる予 後予測}

${ }^{1}$ 西宮渡辺心臟脎血管センター 心臟血管外科, ${ }^{2}$ 済生会和 歌山病院 心臟血管外科, ${ }^{3}$ 済生会和歌山病院 循環器内 科, ${ }^{4}$ 和歌山県立医科大学 第一外科教室

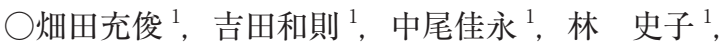
田渕正樹 ${ }^{1}$, 高垣有作 ${ }^{2}$, 和田輝明 ${ }^{3}$, 下角あい子 ${ }^{3}$, 尾鼻正弘 ${ }^{3}$, 西村好晴 ${ }^{4}$

【背景】 Perfusion Index（PI）は,パルスオキシメーターに よって測定できるため, 非常に簡便に, 非侵襲的に測定するこ とができ, 臨床応用が期待されている。重症虚血肢（CLI）は 予後不良であり，一年後の非切断生存率 (Amputation Free Survival:AFS）は $71 \%$ ８9\%とされる。今回，CLI患者の AFS とPIの関連について検討した。

【方法】2017年4月～2018年11月に当院で血管内治療（EVT）を 施行したCLI患者でかつ半年以上追跡可能な62名に対し, EVT 前後でPIを測定し, prePI, postPI, $\Delta$ PI (postPI-prePI) と した。さらに，追跡調查から大切断と死亡をイベントとした AFSを算出した。

【結果】各PIに抢ける ROC曲線の AUC は prePI:0.73,postPI:0.87, $\Delta$ PI:0.79 と, postPIが最も大きく, cut off 值は0.38であった。 postPIのイベント発生の感度,特異度は $88 \%, 76 \%$ であった。こ れまで予後予測因子とされている血清アルブミン值 $<3.0 \mathrm{~g} / \mathrm{dL}$, 慢性腎障害, 年齢 280 才, 冠動脈疾患にpostPI $<0.38$ を加えて重 回帰分析を行った結果，postPIは独立した予後予測因子である ことが示された（オッズ比 $9.15, \mathrm{P}=0.004$ )。

【考察】簡便で非侵襲的な PI，特にEVT 後のPIは，CLI患者の 予後予測に有用である。

Key words : CLI, PI

\section{0-5-4 組織欠損患者における下肢外科的血行再建術前 後のADLの変化と生命予後}

${ }^{1}$ 一般財団法人平成紫川会 小倉記念病院 リハビリテーショ ン課, ${ }^{2}$ 一般財団法人平成紫川会 小倉記念病院 血管外科

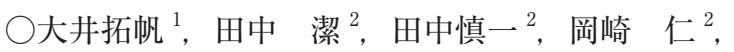
宮川幸大 ${ }^{1}$, 野田喜宽 ${ }^{2}$

【目的】近年，生活習慣病を基礎とする動脈硬化性疾患は増え 続けており，虚血性心疾患や脳血管疾患等と共に末梢閉塞性動 脈疾患 (PAD) も増加している。PADの中でも組織欠損（TL） を有する重症虚血肢（CLTI）患者では，術後の ADL低下が QOL の低下に慗がることが問題となる。そこで術前後の ADL の変化に着目し，生命予後に及ぼす影響を検討した。

【方法】2011年1月から2018年12月にTLを伴うCLTIに対して外 科的血行再建術を施行し，後方視的に評価が可能であった187例 について検討した。入院加療中死亡17例, 大切断 6 例は除外し た。ADLの評価としてBarthel Index（BI）を用い，術後BIが5 点以上向上した患者を ADL 向上群 (H群), 低下を ADL 低下群 (L群), 変化なしを ADL 維持群 (N群) と定義し, 3群において 患者背景及び生命予後を検討した。患者背景はRutherford分類, WI f I分類, 既往歴, 血液生化学デー夕, 左室駆出率, GNRI, minor amputationの有無, BI等を評価した。

【結果】平均観察期間は1123日であった。 $\mathrm{H}$ 群は30例， N 群は 110例，L群は47例であった。3群間において， $\chi^{2}$ 検定では，性 別, minor amputation, 低栄養, HD, $\mathrm{CRP}>0.5 \mathrm{mg} / \mathrm{dl}$ に有意差 を認めた。3年生存率は $\mathrm{H}: \mathrm{N}: \mathrm{L}=78: 68: 37 \%$ と統計学的有 意差を認めた。比例八ザードモデルでは年齢, 栄養, 血液透析, ADL 低下が独立した生命予後規定因子であった。

【結論】BIによる ADLの層別化は生命予後の予測に有用である と考元られた。 $\mathrm{ADL}$ 低下はQOLを低下させるだけでなく生命 予後にも影響を与えるため, 早期の積極的なリハビリ介入によ り $\mathrm{ADL}$ の維持・向上を図ることが重要であると考えられた。

Key words : Barthel Index, tissue loss

\section{0-5-5 血管外科手術におけるせん妄発生因子解析に向 けた前向きコホート研究}

旭川医科大学外科学講座 血管 - 呼吸 - 腫瘍病態外科学分野 ○杤寉 藍, 菊地信介, 竜川貴光, 中津知已, 市川洋平, 吉田有里, 内田大貴, 古屋敦宏, 東 信良

【背景】高齢患者の血管外科手術は増加傾向で，入院・手術・退 院の過程を円滑にする事が肝要である。その障壁の一つである 術後せん妄の発生因子を検討した。

【方法】2019年3月 - 2020 年2月に当教室で血管外科手術を施行さ れた65歳以上かつ，せん妄評価ツールIntensive Care Delirium Screening Checklist (ICDSC) による術前前向き評価がなされ た290手術を解析対象とした。せん妄群（D群）と非せん妄群 (ND群) に分け，血液検查值，術式，背景因子，術前 $\mathrm{ADL}$ 等を 評価し，二項ロジスティック解析で関連因子を同定した。

【結果】術後ICDSC 值が3以上を呈したせん妄は66手術（22.8\%） で発生した。D群では末梢動脈疾患手術例, 術前歩行能衰失例 が多く，WBCやCRP 值が有意に高值であった（P<0.001）。ま た, $\mathrm{D}$ 群は手術時間が長く, 術中出血・輸血量が有意に多かっ た $(\mathrm{P}<0.001)$ 。ND群では術前理学療法開始例 $(\mathrm{P}=0.020)$, 術当 日の経口摂取再開例が有意に多かった $(\mathrm{P}=0.003)$ 。多変量解析 の結果, Distal Bypass オッズ比 (OR) 2.441 (95\%信頼区間 (CI) 1.043-5.715), 認知症 OR $7.048(95 \% \mathrm{CI} 1.843-26.950)$, 術前歩行 能变失 OR $3.300(95 \%$ CI 1.550-7.029), 輸血 OR $2.286(95 \% \mathrm{CI}$ 1.107-4.722), 出血量 OR $1.001(95 \% \mathrm{CI} 1.000-1.002)$, WBC OR 1.000 (95\%CI 1.000-1.000） が術後せん妄に関わる因子として検 出された。

【結論】血管外科手術では長時間手術と術中出血, 輸血を要する 術式はせん妄発生に関与し, 特にDistal Bypassを要する重症下 肢虚血例で術後せん妄が誘発される傾向であった。高齢, 全身 状態不良例に対するせん妄回避のためシンプルかつ有効な血行 再建術の検討と経口摂取をはじめ早期 ADL 改善に努めるべきで ある。

Key words : vascular surgery, delirium 


\section{0-6-1 当院における腸骨領域カバードステントの短期臨 床成績の検討}

${ }^{1}$ 市立函館病院 呼吸器外科, ${ }^{2}$ 市立函館病院 心臟血管外 科, ${ }^{3}$ 札幌医科大学 心臟血管外科, ${ }^{4}$ 札幌医科大学 呼吸 器外科

○大川美穂 ${ }^{1}$, 千葉慶宜 ${ }^{1}$, 保坂 到 $^{2}$, 鶴田航大 ${ }^{4}$, 柴田 豪 $^{3}$, 石川和德 ${ }^{2}$, 新垣正美 ${ }^{3}$, 馬渡 徽 ${ }^{1}$, 森下清文 ${ }^{2}$ 【はじめに】経皮的血管拡張術抢よびステント留置術は, 未梢動 脈疾患 (peripheral arterial disease; 以下 PAD) に対する低侵 襲かつ有効な治療法としてすでに確立されている。2017年7月に 一般販売が開始されたGORE VIABAHN VBX Stent Graftは バルーン拡張型カバードステントであるため, 石灰化の強い病 変に有効とされているが，その治療成績についての単一施設の 臨床成績報告は少ない。

【目的】腸骨動脈領域の狭窄に対するカバードステントVBX Stentの短期臨床成績の評価を目的とした。

【対象】2018年9月から2020年5月の間に, 腸骨動脈領域のPAD と診断され, 血管内治療（EVT）を行った患者のうち, VBX stentを留置した20症例，29病変を対象とした。主要評価項目は EVT後1,3,6,12ヶ月での開存率，救肢率とした。

【結果】症例の内訳は男性 14 人, 女性6人, 平均年齢は72歳であっ た。併存症は高血圧が 16 人, 糖尿病が 9 人, 透析が 4 人で, 喫煙 者が 16 人であった。TASCII/D病変は14肢で認められ, PACSS 分類 grade3,4は8病変であった。病変長の平均は $5.8 \mathrm{~cm}$, 平均 観察期間は6.3か月であった。開存率は1,3,6,12ケ月でそれぞれ 100\%，救肢率もそれぞれ100\%であった。ABIは術前平均0.64か ら術後平均 0.94 と著明に改善した。ステント留置後, 未梢動脈閉 塞または腸骨動脈破裂は生じなかった。観察期間内の死亡例は1 例で, 消化器疾患によるものであった。

【結語】VBXは石灰化の強い病変に対しても良好な治療成績を 示した。

Key words : VBX, EVT

\section{0-6-2 腹部大動脈腸骨動脈病変に対するVBXを用いた 血管内治療の検討}

山口大学大学院器官病態外科学講座 血管外科

○溝口高弘, 森景則保, 竹内由利子, 永瀬 隆, 佐村 誠, 原田剛佑, 未廣晃太郎, 濱野公一

【背景】VBXは強い石灰化を伴うことの多い腹部大動脈腸骨動 脈領域に扔ける閉塞性病変（AIOD）に対してEVTを行う際に, 動脈破裂リスクに対する安全性やステント内狭窄への有用性を 備えた優れたデバイスである。当科では 2018 年12月から 2020 年 4月の期間で14例にVBXを用いた EVTを施行したため, その成 績を retrospectiveに検討した。

【結果】年齢74（61-84）歳, 9例（64\%）が男性であった。ASO が11例で, 急性動脈閉塞が3例であった。ASOの11例において 全てが跛行症例で, Rutherford分類は2群2例，3群9例であった。 ASO11例のうち1例は再治療で, 残り10例の TASC II分類はA 病変3例, B病変1例, D病変6例であった。術式は大動脈留置1例, 大動脈- 総腸骨動脈留置11例, 総腸骨動脈留置1例, 外腸骨動脈
留置1例であった。大動脈-総腸骨動脈留置11例のうち kissing techniqueを用いた症例が8例, terminal aortaにステントグラフ 卜を留置して内腔を平坦化した後に kissing techniqueを用いて VBXを留置したCovered endovascular reconstruction of aortic bifurcation（CERAB）を用いた症例が3例であった。外腸骨動 脈留置の1例はベアメタルステント留置後の plaque protrusion に対し施行した。手術時間167（55-348）分, 出血量70 (0-490) $\mathrm{ml}$, 術後入院期間は5（4-20）日であった。手技成功率 $100 \%$ で, 術中の動脈損傷は認めなかった。患肢の術前 ABIは0.44（0-0.75） で, 術後 ABI は0.88 (0.43-1.47) と有意に上昇した $(\mathrm{p}<0.001)$ 。 周術期死亡 · 合併症は認めなかった。VBX 留置部位への追加治 療を要した症例は存在しなかった。観察期間は4（1-13）ケ月で あった。

【結語】AIODに対してVBXを用いることでより安全にEVTが 施行でき, 良好な初期成績が得られた。

Key words : VBX, stent-graft

\section{0-6-3 浅大腿動脈に留置した薬剤溶出性ステントに対し て慢性期に血管内視鏡をし得た一例}

昭和大学 藤が丘病院 循環器内科

$\bigcirc$ 田代一真, 森 敬善, 和田大輔, 曽根浩元, 武井洋介, 笹井正宏, 佐藤督忠, 鈴木 洋

症例は86歳, 男性。X-20年前より高血圧, 脂質異常症に対して 内服加療を開始した。X-3年前より右下肢の間欠性跛行を自覚し た。内服療法で経過観察されていたが，X-2年前に症状増覀し たため, 精查の結果, 右浅大腿動脈の中間部に高度狭窄を認め, 同部位に対して経皮的末梢血管形成術（EVT）を施行し, 薬剤 溶出性ステント（Zilver PTX®）を留置した。治療後の経過は 良好で症状改善し, 外来経過観察された。X-2か月前より再び右 下肢の間久性跛行を自覚したため, 精查を施行したところ, 右 浅大腿動脈の遠位部に新規の高度狭窄を認めた。同部位に対し て, 血管内視鏡を用いて治療を行った。新规狭窄部位に石灰化 はなく, Uedaらの報告によるプラーク色調分類の Grade2を呈 して抢り, 薬郕コーティングバルーンで拡張を行い, 良好な血 流を得られた。さらに, ステント内にも軽度の再狭窄を認めた ため，血管内視鏡を用いて観察した。ステント挿入から18か月 経過して抢り, 大部分はKotaniらの報告による新生内膜の被覆 度分類Grade3を呈していた。しかし，ステント遠位部の一部に Grade2, 近位部の一部にGrade1を認めた。同一ステント内での 被覆度の不均一について, 原因を検討した。ステント留置時の 血管内超音波では，ステント圧着不良は認めなかったが，ステ ント遠位部と近位部のパーセントプラークエリアが高值であった。 Levin らはパクリタキセルやリムス系の薬剤は脂溶性であり, 脂 質コアに溶け达み長く留まると報告している。本症例に打いて は脂質量の多い部位に沿って, ステントの被覆度が低く, パク リタキセルの効果持続による修復遅延が原因と考えられた。

Key words : angioscopy, stent uncovered 


\section{0-6-4 大腿膝窩動脈領域のステント再狭窄に対する薬 剤溶出性バルーンの有効性と安全性の検討}

総合高津中央病院

○高木友誠, 宮本 明, 吉田善紀, 丸山 高, 久原亮二, 秋田孝子, 福田正浩, 山内靖隆

【目的】大腿滕窩動脈領域のステント再狭窄（ISR）に対する薬 凨コーティングバルーン（DCB）の使用は本邦では保険適用と はなっていないが，海外ではその有用性について報告されている。 今回我々はISRに対する DCB の有効性と安全性について検討し た。

【方法】2018年1月から2019年5月までの期間に，DCBもしくは 非薬片コーティングバルーン（PTA）を用いてISRに対して当 院でEVTが施行された53患者58肢を対象とした。1：1傾向スコ アマッチング後にDCB 群18患者21肢（IN.PACT Admiral 81\%， LUTONIX 19\%), PTA群19患者21肢に分けられ，有効性の評 価として 1 年間の clinically driven target lesion revascularization （CD-TLR）の回避率および開存率を，安全性の評価として 1 年 間の major adverse cardiovascular and leg events (MACLE) の回避率を後ろ向きに比較した。

【成績】患者・病変背景に扔いて2群間で有意差はみられなかっ た（DCB vs PTA，重症虚血肢： $38.1 \%$ vs $33.3 \%$, 維持透析： $33.3 \%$ vs $47.6 \%$, 閉塞病変: $47.6 \%$ vs $33.3 \%$, 病変長: $270 \mathrm{~mm}$ vs $200 \mathrm{~mm}$, BTK run off $\leqq 1$ 枝: $47.6 \%$ vs $38.1 \%$ )。CD-TLR㧍よび MACLEの回避率，開存率はいずれも DCB 群で有意に高かった (66.7\% vs $4.8 \%$ p $<0.001,57.1 \%$ vs $4.8 \%$ p $<0.001,52.4 \%$ vs $4.8 \%$ $\mathrm{p}=0.001)$ 。

【結論】ISRに対するDCBを用いた血行再建は有用である可能性 が示唆された。

Key words : ISR, DCB

\section{0-6-5 DCB (Drug-Coated balloon) により血管内治 療は変わったか?一DCB使用例の初期成績}

藤田医科大学 心臟血管外科

○佐藤俊充, 小林昌義, 高木 靖

浅大腿動脈領域に対する血管内治療では2017年9月にDCBが上 市され当科でも2017年10月から使用を開始した。今回当科で行っ た DCB 使用症例の初期成績を検討した。対象は2017年10月から 2020年3月までに当科で施行した全SFA症例68例中 DCBを使用 した26例（男女比 $18 ： 8$, 平均年齢 $75.3 \pm 5.6$ 歳）とした。比較検 討対象は DCB 使用例（D群）と非使用例42例（ND群，男女比 $33: 9$, 平均年齢 $74.5 \pm 8.3$ 歳）とし, D 群中バイアバーンを併用 したDV 群16例，バイアバーン併用なしのDNV 群10例，ND群 中のバイアバーン併用例 NDV 群 24 例, バイアバーン併用なしの NDNV 群18例を比較した。検討項目は年齢, 開存率 (1年), 下 肢温存率とした。さらに, 透析症例でのDCB 使用の有無 (HDD 群4例, HDND12例）で比較し上記3項目についても検討した。1) $\mathrm{D}$ 群vs ND群: 年齢 $(75.3 \pm 5.6$ 歳 vs $74.5 \pm 8.3$ 歳), 開存率 $(92.3 \%$ vs92.9\%), 下肢温存率（88.5\% VS95.2\%）で有意差認めなかっ た。2）DV 群 vs DNV 群: 年齢 $(73.2 \pm 4.9$ 歳 vs74.3 \pm 6.9 歳), 開存率 $(87.5 \% \mathrm{vs} 100 \%)$, 下肢温存率 $(81.3 \% \mathrm{vs} 100 \%)$ で 3 項
目とも有意差を認めなかった。3）NDV群 vs NDNV 群：年齢 $(73.9 \pm 2.5$ 歳 vs $75.8 \pm 8.4$ 歳), 開存率 $(87.5 \%$ vs $94.4 \%)$, 下肢温 存率 $(91.7 \%$ vs $100 \%)$ で3項目とも有意差は認めなかった。4) HDD 群 vs HDND 群 : 年齢 $(71.3 \pm 5.7$ 歳 vs74.2 \pm 9.4 歳), 開存率 $(100 \%$ vs $100 \%)$, 下肢温存率 ( $50 \%$ vs $100 \%)$ で下肢温存率の 久有意差を認めた $(\mathrm{P}=0.03)$ 。透析例では $\mathrm{DCB}$ 使用例（HDD 群） で下肢切断2例認めたが, 足趾感染制御不能によるものであった。 DCBを使用しても既存のデバイスと成績は不変であった。透析 例は感染制御が重要点と思われた。

Key words : DCB, SFA

\section{0-6-6 Papaverine薬剤負荷併用での圧較差・FFR測定 を用いたPAD血管内治療の有用性}

${ }^{1}$ 日野市立病院 放射線科, ${ }^{2}$ 日野市立病院 外科 ○三浦弘志 ${ }^{1}$, 一坂俊介 ${ }^{2}$

2019年5月から2020年4月までに, 跛行症状を主訴とする下肢動 脈PADにEVT 施行した7症例（60歳代から70歳代, 男性6例, 女性1例）で, TASC2 A 病変を主とする外腸骨動脈狭窄1例・ 総腸骨動脈狭窄 1 例 $-\mathrm{SFA}$ 泆窄 3 例/閉塞 1 例・滕窩動脈狭窄（プ ラスSFA 狭窄）1例において，0.014 guiedwire対応の monorail type Rapid Exchange FFR microcatheter (ACIST Navvus) を用いて Papaverine $30 \mathrm{mg}$ 負荷及び非負荷で圧較差と FFRを 測定し（総腸骨動脈狭窄は4Fr straight catheterで圧較差の み), 治療効果判定の指標とした。SFA病変に対しては cuttiing balloon + long inflation balloon angioplasty 後に DCB (In-Pact4 例，LUTONIX1例）使用して stentは使用せず，外腸骨動脈狭 窄もnon stenting zoneに近い部位でcutting balloonのみ治療 したが総腸骨動脈狭窄にはballoon expandable stent（Express LD）留置した。SFA閉塞1例のみ PTA後早期に再閉塞きたし re-interventionせずFP bypassへ convertしたが他はABI改善し 臨床的に改善を得た。SFA 狭窄は単区域狭窄 2 例 - 複数区域狭 窄（2ケ所 1 例, びまん性狭窄含めた 2 ケ所 1 例) で, 畓窝動脈 + SFA 狭窄は合計3ヶ所狭窄であった。治療前では非負荷時と比べ 負荷後には圧較差増強と FFR 低下の増幅が強調された。治療後 では両值とも顕著な改善が認められたが，負荷後にわずかな残 存が見られた。また複数狭窄例では責任部位を把握することが 可能であった。1例のみ治療前 papaverine 投与後に一過性の下 肢痛きたし速やかに消失したが治療後には投与しても症状発生 しなかった。本法により今後治療適応の判断や再狭窄の予測に ついても有用な情報が得られる可能性があると思われた。

Key words : Pressure Gradient, administration of Papaverine

\section{0-7-1 膝窩動脈に留置されたステントが閉塞したため血 行再建を要した 1 例}

獨協医科大学 ハートセンター 心臟・血管外科 ○廣田章太郎, 大橋裕恭, 加藤 昂, 関 雅浩, 手塚雅博, 武井祐介, 小川博永, 柴崎郁子, 緒方孝治, 福田宏嗣 はじめに

血管内治療（endovascular treatment;EVT）の進歩に伴い，大 腿滕窩動脈領域においてもその適応が拡大してきている。しか 
し, 膝窩動脈に関しては基本的に血管内治療の適応はない。今回, 滕窩動脈に留置されたステントが閉塞したため手術を要した症 例を経験したため報告する。

症例

43 才男性。3 8 歳時から右下肢間欠性跛行を自覚。40 歳時 に下肢閉塞性動脈硬化症の診断にて循環器内科でEVT施行。浅 大腿動脈末梢から膝窩動脈中枢に病変あり, バルーン形成を試 みるも拡張不十分, 動脈壁の解離も認めたため, ステントが留 置された。一旦症状改善も, 42 歳時に再度間欠性跛行出現し EVT施行。滕窩動脈, 右前脛骨動脈に閉塞あり, EVT施行後も, 血流十分確保できず，抗凝固療法が開始された。4 3 歳時に右 膝窩動脈ステント閉塞認め, 跛行の進行もあることから, 外科 的手術の適応と判断され, 当科紹介となった。症状は $50 \mathrm{~m}$ 程度 の間欠性跛行であったが, 若年で日常生活に高度の支障をきた していることから血行再建を行うこととした。手術は腹臥位に てステントごと内膜摘除を行い, 同側小伏在静脈を用いてパッ チ形成を施行した。ステントは一部破損しており，閉塞原因と 考えられた。術後, 間欠性跛行は消失し, 合併症なく退院した。 考察

右膝窩動脈ステント閉塞に対して, ステント抜去, 内膜摘除, パッ チ形成術を要した症例を経験した。閉塞部周囲の側副血管が発 達していたため，同血管を温存する目的で血管置換術ではなく 本術式を選択した。血管内治療は低侵襲であるが, 解剖学的適 応を十分に考慮した上で施行することが重要であると再確認した。 Key words : stent occlusion, popliteal thrombendarteriectomy

\section{0-7-2 外傷後大腿部軟部組織欠損・瘢痕治癒した慢性虚 血肢の浅大腿動脈再建}

${ }^{1}$ 獨協医科大学 心臓 - 血管外科, ${ }^{2}$ 前橋赤十字病院 心臓 血管外科

○緒方孝治 ${ }^{1}$, 関 雅浩 ${ }^{1}$, 手塚雅博 ${ }^{1}$, 桑田俊之 ${ }^{2}$, 柴崎郁子 ${ }^{1}$, 小川博永 ${ }^{1}$, 武井祐介 ${ }^{1}$, 加藤 昂 $^{1}$, 大橋裕恭 ${ }^{1}$, 廣田章太郎 ${ }^{1}$, 福田宏嗣 ${ }^{1}$

【はじめに】第57回日本脈管学会総会で9歳男児の交通外傷によ る浅大腿動脈断裂に対する血行再建術の報告を行った。人工血 管による浅大腿動脈再建を行ったが，感染のため人工血管抜去 し慢性経過となっていた。14歳時に再度右浅大腿動脈再建術を 施行したので報告する。

【経過】2014年7月に受傷。骨盤骨折，右大腿部挫創，両側大腿 骨開放性骨折を認め, 右浅大腿動脈が断裂しており, 緊急の止 血・血行再建が必要であった。両下肢を受傷していることもあ り，開放創であったがやむなく $6 \mathrm{~mm}$ ePTFEで右浅大腿動脈再 建を行った。しかし，人工血管感染のため術後 25 日目に人工血 管抜去した。膝窩動脈のドップラー音は聴取可能であったので, 追加血行再建は行わなかった。その後, 下肢切断は免れ, 装具, 杖を使用して自力歩行は可能であったが, 左下肢長は短く, 大 腿部の軟部組織は大きく欠損し㓔痕治癒, 大腿骨は変形治癒, 足部は尖足の状態なっていた。今回右下腿骨延長術が計画され たが，血流不足が危惧されたため，再血行再建術を先行する方 針となった。しかし, 右大腿部の痏痕治癒のため, バイパスグ
ラフトを通常のルートに通すことが困難と考えられたため, 右 大腿部の遊離皮弁移植術をさらに先行する方針とした。

【治療】2019年10月, 当院形成外科で右大腿部内側に遊離肩甲皮 弁移植術を施行した後，2020年1月に右総大腿－浅大腿動脈バイ パス（r-SVG 大腿前面皮下ルート）を施行した。 $\mathrm{ABI}$ は術前 0.62から術後1.04に回復し, 現在右下腿延長術の待機中である。

【結語】外傷後軟部組織欠損・痏痕治癒肢であったが, 遊離皮弁 移植術を先行することにより, バイパスグラフトを通すことが 容易となった。

Key words : vascular injury, revascularization

\section{0-7-3 急性動脈閉塞を繰り返し重症虚血となったためバ イパス術を施行した 1 例}

獨協医科大学病院 ハートセンター 心臓・血管外科

$\bigcirc$ 手塚雅博, 廣田章太郎, 大橋裕恭, 加藤 昂, 関 雅浩, 武井祐介, 小川博永, 緒方孝治, 柴崎郁子, 福田宏嗣 【はじめに】急性動脈閉塞を繰り返し, 慢性閉塞となったのち安 静時痛をきたした症例に対し, 腋窝動脈-尺骨動脈バイパス術を 施行して救肢し得た1例を経験したため報告する。

【症例】83歳女性, 小児麻痺に伴う右不全麻痺に対して松葉杖を 使用していた患者。心房細動の既往は無し。2018年7月右上肢の 冷感および疼痛にて受診。検査にて右腋窝から上腕動脈閉塞あ り, 緊急血栓除去術施行。腋窩動脈にくびれは残ったが血流再 開し, 術後はアスピリン/ランソプラゾール配合錠を開始し退 院となった。2018年12月再度右上肢冷感, 疼痛を自覚し受診。 右腋窩から上腕動脈が再閉塞していたため緊急血栓除去術施行。 ワイヤがかろうじて通過したためFogartyカテーテルにて血检 除去を試みたが血栓は摘出できず，バルーンが通過した部位に かろうじて血流が再開した。腋窩動脈狭窄部が起点と考えられ る慢性閉塞病変であった。エドキサバンを追加し, 退院となった。 2019年6月右手冷感, 安静時痛を認めるようになり受診。CTで は上腕動脈は前回と同じ部位から閉塞, 前腕では尺骨動脈のみ 側副血行を介して造影された。PGE1製剤投与にて保存的加療を 行うも病状改善しなかったため, 大伏在静脈を用いて右腋窩動 脈-尺骨動脈バイパスを施行した。術後安静時痛は消失し, 退院 となった。現在はバイアスピリン, シロスタゾール内服継続し 外来経過観察中である。

【考察】本症例の動脈閉塞の原因は心房細動の既往もないことか ら血栓塞栓症の可能性は低く, 閉塞起点が腋窩動脈であること から長期松葉杖使用に伴う外的刺激による腋窩動脈の内膜肥厚 が原因となった可能性が考えられた。

Key words : Upper limb bypass, Critical limb ischemia 


\section{0-7-4 心房細動をもつ非喫煙マラソン愛好者に発症した 下肢慢性動脈閉塞症の 2 例}

${ }^{1}$ 藤田医科大学 岡崎医療センター 消化器外科, ${ }^{2}$ 藤田医 科大学 ばんたね病院 外科

$\bigcirc$ 神尾健士郎 ${ }^{1}$, 永田英俊 ${ }^{2}$, 近藤ゆか ${ }^{2}$, 東口貴彦 ${ }^{2}$, 安岡宏展 ${ }^{2}$, 越智隆之 ${ }^{2}$, 林 千紘 ${ }^{2}$, 志村正博 ${ }^{2}$, 加藤宏之 ${ }^{2}$, 荒川 敏 ${ }^{2}$, 浅野之夫 ${ }^{2}$, 川辺則彦 ${ }^{2}$, 伊東昌広 ${ }^{2}$, 堀口明彦 ${ }^{2}$ 【症例 1】69歳男性。病歴：5 年前より左下肢痛が時々出現す るも放置していた。冷感も加わったため受診した。生活歴：夕 バコ50年前より禁煙, 趣味: 年 1 回フルマラソン参加。来院時 ABI : 右 0.52 左 0.32 , 心電図 : 心房細動, 造影 $\mathrm{C} T$ : 左腸骨動脈 閉塞, 两側浅大腿動脈は閉塞, 側副血行路で滕窩動脈以下は造 影されていた。内服療法を行っていたが，左下肢症状の急性増 悪があり, 右外腸骨-左大腿動脈, 左大腿-滕窩人工血管バイパ 又を施行した。術後 $\mathrm{ABI}$ は右 0.57 , 左 0.56 に回復し退院した。

【症例 2】66歳，男性。1か月前より左下腿間欠性跛行が出現。 徐々に増悪, 右にも同様経過が出現してきたため受診, 緊急入 院した。既往歴： 3 年前小脳梗塞, 高血圧, 心房細動で内服中。 喫煙歷なし。趣味; マラソン, テニス。入院時 $\mathrm{ABI}$ : 右測定不能, 左0.30, 造影 $\mathrm{C} T$ : 左腸骨動脈から浅大腿, 䐐窝, 下腿動脈は描 出され側副血行路を介して足部動脈が描出されていた。右下肢： 外腸骨動脈から滕窝, 下腿動脈も描出されなかった。入院後抗 凝固療法を行った後血行再建術を施行した。手術：両側大腿動 脈を切開しFogarty 血栓摘除術を施行。腸骨動脈, 浅大腿動脈 の血栓は除去できたが, 膝窩動脈をカテーテルは通過しなかった。 鼠径部から動注カテーテルを留置して手術を終了した。術後 $\mathrm{A}$ B I は, 右 0.63 , 左 0.55 に改善した。

【まとめ本症例の病因が血栓塞栓症か閉塞性動脈硬化症かは不 明である。しかし 2 例とも非喫煙者，スポーツ愛好者で動脈硬 化症リスクファクターも低いなど閉塞性動脈硬化症患者として は非定型的で心房細動の関与が示唆された。

Key words : AF, chronic arterial occlusion

\section{0-8-1 当科におけるCLTIに対するハイブリッド治療の成 績について}

${ }^{1}$ 静岡赤十字病院 血管外科, ${ }^{2}$ 静岡赤十字病院 心臟外科

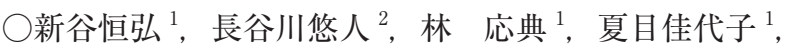
大倉一宏 ${ }^{2}$

【目的】大動脈腸骨動脈領域から滕下末梢動脈領域に渡る広範囲 病変に伴うCLTI（重症下肢虚血）に対し創傷治癒のために完全 血行再建を達成するには，血管内治療（EVT）あるいは外科的 治療（Open）単独では困難なことが多く，ハイブリッド治療が 有用なことがある。当科に扔けるCLTIに対するハイブリッド治 療の成績につき報告する。

【対象と方法】2015年から2020年3月までに創傷を合併した広範 囲病変に伴うCLTI（R5,6）に対しハイブリッド治療により完全 血行再建を達成し得た18例19肢を対象とした。創傷治癒率，主 要有害下肢イベント, 下肢切断回避率につき評価し, 創傷再発 に関する危険因子を検索した。

【結果】患者の内訳は平均年齢 $76.7 \pm 8.6$ 歳, 男性12例13肢, 平均
経過観察期間 $22.0 \pm 17.3$ 个月であった。病変の内訳はGLASS 分 類 (II:10肢, III:9肢), WIFI分類 (2:3肢, 3:1肢, 4:15肢) であっ た。早期下肢切断を 1 例経験したが, 残り19肢全てに創傷治癒が 得られた。平均創傷治癒日数は 40 日, 2 年主要有害下肢イベント, 下肢切断回避率はそれぞれ $54.5 \%, 63.6 \%$ てっった。経過観察中 に6肢（33.3\%）の創傷再発を経験し，1 例が下肢切断に至った。 浅大腿滕窝動脈病変に対する外科的治療に扔いて高い創傷再発 を認めたが統計学的に有意ではなかった。

【考察】解剖学的難易度が高く, より重篤な感染病変に対し八イ ブリッド治療にて早期の高い創傷治㾍が得られたが，長期的な 成績は不良であった。浅大腿膝窩動脈病変に対する薬片溶出性 バルーンやステントの良好な成績が報告されており，これらを 併用したハイブリッド治療に期待が持たれる。

Key words : CLTI, Hybrid

\section{0-8-2 Distal bypassでの末梢側石灰化病变に対する 内膜摘除術}

${ }^{1}$ 社会医療法人愛仁会 井上病院 血管外科, ${ }^{2}$ 住友病院 IVR センター

$\bigcirc$ 谷村信宏 ${ }^{1}$, 西本幸弘 ${ }^{2}$, 大仲玄明 ${ }^{2}$, 山本浩詞 ${ }^{2}$, 安宅啓二 ${ }^{2}$

【はじめに】当院は透析症例のCLTIを多数経験しており, 従来 EVT firstの方針で行っているが，EVTのみでは治癒しない症 例も多く, 積極的に外科的血行再建 : distal bypassも考慮して いる。この際に末梢側吻合予定部の石灰化により, 手術適応に 苦虑する場合も多い。

【結果】麻酔は全身麻醉が基本であるが, 神経ブロック（PNB） を多用し, 重症例ではPNBのみで手術を行っている。今回 distal bypassの末梢側吻合部の石灰化病変に, 内膜摘除を行っ て末梢側吻合を行った2例を経験した。2例とも年齢は80歳台で, 男女各1例である。術式は, Distal SFA-DPA bypass と CFADPA bypassで, 2例目ではCFAにも内膜摘除を行った。末梢 側吻合部の内膜摘除は剥離範囲が20-30 mm と長くなる傾向にあっ たが, toe 側の内膜が比較的良好になる部位とし, 静脈グラフト を吻合切開部全体に対して on-lay patch様に端側吻合した。い ずれも術後急性期の開存性は良好で, 1例は残念ながら退院後の 術後45日に突然死したものの, もう1例は術後38ケ月 グラフト も良好に開存している。

【考察及び結語】石灰化病変に対する内膜摘除は, 血管外科医に とっては基本的手技であるが，総大腿動脈病変に行う機会が多く， 足関節以下の動脈に行うことはほとんどない。当科では以前に 足背動脈の単独石灰化狭窄病変に対して内膜摘除 +パッチ形成 を行って良好な長期開存を得た経験があり，その経験も踏まえ て今回の手技を行い，良好な結果が得られた。末梢側吻合予定 部での石灰化病変は, 内膜摘除によって吻合可能となる症例も あり, Distal bypassの適応拡大に寄与する可能性があると思わ れる。

Key words : distal endarterectomy, distal bypass 


\section{0-8-3 腎移植患者に対するバイパス術後下肢救済成績は 透析患者よりも不良である}

江戸川病院 血管病センター

○鎌田啓輔, 小久保拓, 名木田明幸, 笹嶋唯博

【背景】高度腎機能障害例の包括的高度慢性下肢虚血（CLTI） に対する末梢動脈バイパスでは維持透析（HD）に比べ腎移植 （RT）患者は生命予後抒よび術後成績が良好とする報告が多い。 しかし糖尿病を主な基礎疾患とするCLTIでは免疫抑制剂やステ ロイド投与による感染の影響は無視できず，CLTI重症度や血行 再建術式を考慮した検討が必要である。今回，CLTIに対する末 梢動脈バイパスについて HD 群とRT群の治療成績を検証した。

【対象・方法】過去 6 年間で組織欠損を伴うCLTIに施行された 末梢動脈バイパス術は324例／392肢で， HD またはRT例に施行 されたのは159例 $/ 201$ 肢（HD 147例 $/ 185$ 肢, RT 12例 $/ 16$ 肢） であった。術式は大腿滕窝動脈バイパス21肢 (10.4\%)，下腿動 脈バイパス 17 肢 $(8.5 \%)$, 足関節以下へのバイパス 161 肢 $(81.1 \%)$ で，90\% が下腿から足部動脈へのバイパスであった。バイパス 開存率, 救肢率, 創治痛率, 生存率を両群間で比較した。

【結 果】HD 群で高血圧 $(\mathrm{p}=0.01)$, WIfI 分類 Ischemia スコ ア（ $\mathrm{p}=0.049 ）$ が有意に高値であった他，両群間の術前背景 因子に有意差を認めなかった。 RT vs HDの 2 年一次開存率 ( $51.7 \%$ vs $70.2 \%, \mathrm{p}=0.133)$, 生存率（ $48.0 \%$ vs $26.5 \%, \mathrm{p}=0.116)$, Amputation free survival ( $38.5 \%$ vs $24.0 \%, \mathrm{p}=0.483)$ に有 意差を見いだせかったが，2年二次開存率（ $54.7 \%$ vs $86.7 \%$, $\mathrm{p}=0.004)$ ，創治癒率（ $26.7 \%$ vs $54.9 \%, \mathrm{p}=0.006 ）$ および5年救肢 率（64.5\% vs $88.5 \%, \mathrm{p}=0.005 ）$ はT群で有意に不良であった。

【結論】末梢動脈バイパス例の中でも足部以下へのバイパスを要 するCLTI例では, RT 群で有意に下肢救済率が不良で, 免疫抑 制剂やステロイド治療による感染コントロール不良が救肢率を 低下させる大きな要因と推察された。

Key words : Renal transplantation, CLTI

\section{0-8-4 超高齢者のCLTII対する外科的血行再建の妥当性}

済生会八幡総合病院 血管外科

○郡谷篤史，吉賀亮輔，三井信介

【目的】90歳以上の超高齢者CLTIが散見されるが，一般的に， 超高齢者は多くの疾患を合併して损り，外科的血行再建が敬遠 される傾向にある。当院で行われた超高齢者CLTIの血行再建の 成績を比較し，外科的血行再建の妥当性を検討した。

【方法】2015年12月から2020年2月に血行再建を行った90歳以上 の超高齢者CLTI 20例，22肢を外科的血行再建14肢（OR群）と EVT 8肢（EV群）に分け，後ろ向きに検討した。

【成績】年齢は OR 群92.3歳, EV 群92.6歳。活動レベルは歩行可 能 OR 群 $58.3 \%$ ， EV 群 $50.0 \%$ ，起立不能 OR 群 $0 \%$ ， EV 群 $25.0 \%$ 。 患者背景に有意差を認めず，起立不能例ではEVTが選択され ていた。OR群はRutherford4，5，6が35.7\%，50.0\%，14.3\%， $\mathrm{EV}$ 群は25.0\%，62.5\%，12.5\%（p=ns），OR群は GLASSstage3 が100\%，EV 群は GLASSstage1，2，3が12.5\%，62.5\%，25.0\% $(\mathrm{p}<0.05)$ 。血行再建の方法はGLASSstage と相関関係を認めた。 $\mathrm{OR}$ 群は大腿動脈内膜摘除2肢 $(14.3 \%)$, バイパス血管は㮏上滕
窝2肢 $(14.3 \%)$, 膝下滕窩3肢 $(21.4 \%)$, 下腿7肢 $(50 \%), \mathrm{EV}$ 群の再建動脈は腸骨 2 肢 $(25 \%)$, 浅大腿1肢 $(12.5 \%)$, 膝窩2肢 (25\%)，下腿 3 肢 $(37.5 \%)$ であった。手術死亡はなく, OR 群 の1例が術後39日に肺炎で在院死した。生存率は, OR 群が1年 $66.1 \%, 2$ 年 $44.1 \%, E V$ 群が 1 年 $37.5 \%, 2$ 年 $37.5 \%(\mathrm{p}=0.45)$ 。開 存率は, OR 群が2年一次 $21.6 \%$, 二次 $71.1 \%, \mathrm{EV}$ 群が2年一次 $87.5 \%$ ，二次 $100 \%$ と有意差なく，全例で大切断は認めなかった。 潰瘍治癒または安静時痛消失率は，OR群 $78.6 \%, \mathrm{EV}$ 群 $37.5 \%$ （ $\mathrm{p}=0.054 ） と \mathrm{OR}$ 群で症状が改善する傾向にあった。

【結論】外科的血行再建は, 症例を適切に選択すれば，超高齢者 CLTIに扔いても, 安全かつ有効な結果が得られ, 妥当な治療法 と考えられた。

Key words : Chronic limb-threatening ischemia, Nonagenarian

\section{0-8-5 血液透析患者のdistal bypass後生命予後予測 におけるBrain natriuretic peptideの意義}

\section{江戸川病院}

○名木田明幸，鎌田啓輔，小久保拓，笹嶋唯博

【目的】様々な併存疾患を持つ chronic limb threatening ischemia （CLTI）に対する para or inframalleolar bypass (PIMB) を行っ た患者について生命予後予測に执けるbrain natriuretic peptide （BNP）の意義を検証した。

【方法】CLTI患者の術前血漿BNPを測定し, 術前WIFi虚血重 症度, 術後の生命予後との関係を後ろ向きに解析した。過去8年 間でPIMBを行った256例に術前BNP測定を実施した。内訳は血 液透析群 $(\mathrm{HD})(155$ 例 $)$ ·非透析群（NHD）（101例）。それぞ れの群でBNP cut off 值を設定し (透析 HD 群 $475 \mathrm{pg} / \mathrm{ml}$, 非透 析 NHD 群 $60 \mathrm{pg} / \mathrm{ml}$ ) で高値 vs. 低值の2群に分けBNPの相関因 子を解析した。

【結果】HDではBNP 高值群で, WIfI 虚血項 grade $>2 か ゙$ 多く,生 命予後は有意に不良であった（ $<<0.05 ）$ 。NHDではBNP 高值群 で心房細動, 治療歴を有する冠動脈疾患が多かったが, 生命予 後には有意な関係を認めなかった。

【結論】BNPはCLTIに対しPIMBを受けたHD患者の生命予後 予測因子として有用である。

Key words : BNP, CLTI

\section{0-8-6 糖尿病患者のLimb SalvageにおけるOff- Loadingの重要性について}

${ }^{1}$ 新須磨病院 外科, ${ }^{2}$ 新須磨病院 形成外科, ${ }^{3}$ 日本フット ケアサービス

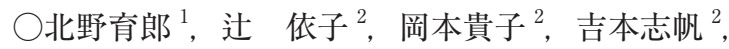

辻 義彦 ${ }^{1}$, 山口篤史 ${ }^{3}$

糖尿病性足病変とは, 単一の病態を示すものではなく, 下肢 の虚血, 神経障害, 創部感染の複合性病変である。糖尿病患 者の Limb Salvage（救肢）を考える上で, 創 (Wound)・虚血 (Ischemia) ・感染（Foot Infection）の 3 つの因子が重要で, 頭 文字をとってWIFi分類が発表された。また，虚血以外の創傷・ 組織欠損の状態, 足部感染などの下肢切断リスクを持ち, 治療 介入が必要な下肢の総称として, 今回 CLTI（包括的高度慢性 
下肢虚血）の概念が提唱された。これは, 高度な虚血の観点の みで定義された従来のCLI（重症下肢虚血）では下肢の予後が 必ずしも正確に反映されず，より包括的かつ的確な疾患分類が 求められたことからできた概念である。糖尿病患者においては, 動脈硬化性病変としてのCLI と, 糖尿病の合併症である足病変 （神経障害，易感染性）の両方の側面から救肢を考える必要があ るといえる。特にCLTIにおいては，創を作らない，また再発 させないための Off-Loading (免荷) が極めて重要となってくる。 今回, Limb Salvageのための Off-Loadingの重要性について, 歩 行機能やfoot wearを含めて報告する。

Key words : Limb Salvage, Diabetic foot

\section{0-9-1 下肢静眽瘤治療における看護師の役割-血管内塞 栓術でどう変わったか-}

${ }^{1}$ 西の京病院 看護部, ${ }^{2}$ 西の京病院 血管外科

$\bigcirc$ 黒瀬満梨奈 ${ }^{1}$, 今井崇裕 ${ }^{2}$

2011年より下肢静脈瘤に対する血管内焼灼術が国内で保険適応 となった。現在, 当院では下肢静脈瘤に対してレーザーやラジ オ波による伏在静脈の治療と stab avulsion法による瘤切除を標 準術式としている。また2019年よりVenaSealを使用したNTNT ablation が国内で保険適応となり, 当院では本年1月から治療を 開始した。この治療ではstab avulsionによる瘤切除を同時に行 わないことが一般的であるため, 術後下肢の巻き上げや弾性ス トッキングによる圧迫は不要である。加えて血管内焼灼術のよ うに熱による組織へのダメージが少ないため, 術後の疼痛や疩れ も少ないと言われている。以上の理由で, より低侵襲であるため 今後この治療の普及が見込まれている。今回, 血管内焼灼術と VenaSeal を使用したNTNT ablationの術後看護のポイントにつ いて比較検討した。対象は2020年1月から下肢静脈瘤で血管内焼 灼術とVenaSeal を使用したNTNT ablationの治療を受けた患者 各18名。検討項目はVASスケールを使用した術後疼痛, 瘏れの 有無など患者の訴えに対する聞き取り調査内容。内出血の程度 やアレルギー反応の有無に関する術後外観上の変化とした。上 記内容につき, 術後看護のポイントについて検討した結果を報告 する。

Key words : varicose veins, VenaSeal closure system

\section{0-9-2 血管外科領域疾患に併存した内頝動脈狭窄CEA 例の検討}

日本大学医学部附属板橋病院

白水御代, 前田英明, 飯田絢子, 石井雄介, 河野通成, 原田 篤, 田中正史

目的：閉塞性動脈硬化症, 腹部大動脈瘤, 透析患者において, 術前, 術後の脳梗塞合併例頻度は高く, 時に, QOL, 生命予 後不良となる事がある。当科では, 日常血管疾患例に頚部血管 聴診上雑音聴取例は超音波検査を行い, 当科治療安全性を考慮 して頸動脈血栓内膜除去術 CEAを行っている。今回, その適 応と予後について検討した。対象と方法：2005年5月 - 2019年 10 月に当科術前 - 経過観察中に頸動脈雑音を聴取し, 超音波検 査上狭窄部 PSV $\geqq 200 \mathrm{~cm} / \mathrm{s}$ を CEA 手術適応とした。55例 60 病
変にCEAを施行した。男性 54 例，女性6例，平均年齢 $77.8 \pm 5.9$ 歳で, 手術部位は右34例, 左 21 例, 両側異時5例。腹部大動脈 瘤人工血管置換術, TEVAR, CABG と同時手術を 3 例に行っ た。結果：併存血管外科領域疾患はASO 29例, 腹部大動脈瘤5 例, 胸部大動脈瘤 2 例, 腸骨動脈瘤 1 例, 慢性腎不全 10 例であっ た。5例に PCI，2例にCABG 歴があった。術前超音波検査で狭 窄率はNASCET 40-83\%, PSV88.5-600 cm/ secで, 全例 MRAか MDCT で病変の形状と高さを確認しほぼ全例シャントチューブ を使用した。CEA術後早期死亡は認めず, 後遺症を伴う脳梗塞 1を認めた。結語：血管外科領域疾患に合併した内澒動脈狭窄 例は冠動脈疾患, 慢性腎不全合併 polyvascular disease例である が, CEA 早期死亡, 在院全例退院可能であった。当科では原則 $\mathrm{PSV} \geqq 200 \mathrm{~cm} / \mathrm{sec}$ で病変が $\mathrm{C} 2$ 以下を手術適応とし, CEAを行い, CASよりも，安全な術式であることが再確認できた。

Key words : CEA, ICA

\section{0-9-3 COVID-19による外出制限により下肢動脈閉塞 の再燃を来した一例}

帝京大学 医学部 内科学講座

○小修平, 横山直之, 行光 望, 名倉福子, 日置紘文, 上妻 謙

症例は80歳男性。陳旧性心筋梗塞（OMI）に対する冠動脈形成 術（PCI）後のリハビリ中に間欠性跛行が出現し，精査で両側 浅大腿動脈（SFA）近位部の閉塞を認めた。同部位に対する血 管形成術（EVT）を施行し, 術後歩行リハビリテーションで症 状の改善を認めた。以後, 外来通院していた。COVID-19の䒤延 により自宅安静を行っていたところ, 間欠性跛行の再燃を認め, 精査でEVT後左SFA ステント内閉塞を認めた。自宅安静によ る下肢動脈血流低下が関与していると考えられ，ここに報告する。 Key words : ftw, shu

\section{0-9-4 新型コロナウイルス感染症に罹患した重症虚血肢 の 1 例}

慶應義塾大学 医学部 外科学教室

○細川恭佑, 松原健太郎, 鳥崎友紀子, 菊池直哉, 神谷悠紀, 尾原秀明, 北川雄光

【緒言】重症虚血肢に対する治療の第1の目的は肢切断を回避す ることであり, 迅速かつ確実な血行再建が求められる。一方, 2019年12月以降, 世界中へ流行した新型コロナウイルス感染症は, 感染対策の観点から様々な疾患の治療方針にも影響を及ぼして いる。今回われわれは，新型コロナウイルス感染症に罹患した 重症虚血肢の1例を経験したので報告する。

【症例】72歳男性, 大動脈弁置換術, 冠動脈バイパス術, 生体腎 移植の既往があり，ワルファリンを内服していた。以前より左 間欠性跛行と左浅大腿動脈から膝窩動脈の完全閉塞および下腿 動脈病変を認めていたが, 包括的高度慢性下肢虚血（CLTI）に は至っておらず，外来フォローされていた。他院にて心不全の 加療目的で入院した際に, 左下肢虚血が急速に進行し足趾潰瘍 を生じたため, 治療目的に当院へ転院となった。当院転院時に はCT 検査, 臨床症状ともに肺炎を示唆する所見を認めなかっ 
たが, PCR 検査にてSARS-CoV-2感染（無症候性）が判明した。 COVID-19に対して抗ウイルス薬（ファビピラビル）等の薬物治 療を開始したが，その後，呼吸状態が急速に悪化し，挿管管理 となった。ステロイドパルス療法, 抗凝固療法を含めた集中治 療にて救命することができたが，その間に足趾の壊死が進行し， 左大腿切断となった。

【結語】COVID-19肺炎に対する抗凝固療法が注目されているが, 本症例はもともとワルファリンを内服しており, 呼吸状態悪化 後もへパリンによる抗凝固療法を継続したことが救命に寄与し た可能性がある。CLTI患者がCOVID-19となった場合には, 救 命しつついかに救肢するかが課題である。

Key words : CLTI, Covid-19

\section{0-10-1 傍腎動眽腹部大動脈瘤に対するopen repairの 治療成績}

奈良県立医科大学 胸部 - 心臓血管外科

$\bigcirc$ 廣瀬友亮, 阿部毅寿, 早田義宏, 平賀 俊, 福場遼平, 武村潤一, 殿村 玲, 三谷和大, 横山晋也, 谷口繁樹

【背景・目的】傍腎動脈腹部大動脈瘤（JAAA）は腎動脈下腹 部大動脈瘤と比較し手術侵襲が高く, 腎機能障害の可能性が高 い。EVARは通常のデバイスでは適応外であり, Chimney 法 (c-EVAR) やFenestration 法 (f-EVAR) が必要であるため, open repair (OR) が第一選択である。今回, われわれはORの 治療成績を検討したので報告する。

【対象】2008年1月から2019年12月までにAAAの診断で緊急お よび透析症例を除き ORを施行した症例は304例であった。その うち腎動脈上遮断を要したJAAAの症例は62例であった。平均 年齢は $71.5 \pm 6.7$ 歳, 男性 58 例, 女性 4 例であった。全例腹部正 中切開でアプローチし，25例で両側腎動脈上遮断，37例で片側 腎動脈上遮断を行った。腎保護のため腎動脈内腔にカニュレー ションし $4^{\circ} \mathrm{C}$ の冷却リンゲル液で灌流を行った。腎機能障害は KDIGO分類で評価した。

【結果】術前CKD stageはstage2が29例, stage3が30例, stage4 が3例であった。術後30日死亡は認めなかった。術後合併症は肺 炎 2 例, 対麻痺 1 例, 下肢再灌流障害 1 例, 乳び腹水 1 例, 心筋梗 塞1例認めた。腎機能障害は12例に認められた。KDIGO 分類で stage1が9例, stage2が3例で, うち9例は退院時には術前の数值 に改善していた。遠隔死亡は7例（4例：心疾患, 1例：胃癌, 1例 : イレウス，1例：事故）認めたが，瘤関連による死亡は認めなかっ た。

【結語】当科ではJAAAに対して第一選択はORを選択している。 ORの際，腎灌流を使用することで腎障害を防ぎ得た。

Key words : juxtarenal, open repair

\section{0-10-2 傍腎動眽腹部大動脈瘤に対しParallel graft techniqueを用いて治療し得た 1 例}

${ }^{1}$ 東京巨樹の会 東京品川病院 血管外科, ${ }^{2}$ 石心会 川崎 幸病院 放射線科

$\bigcirc$ 光岡明人 ${ }^{1}$, 守屋信和 ${ }^{2}$

傍腎動脈腹部大動脈瘤に対する治療の第一選択は開腹人工血管 置換術である。しかし耐術不能症例に対しては endovascular aortic repair（EVAR）を選択せざるを得ない。しかしChimney 法を用いたEVARは, gutter leakが生じ治療が不完全になるこ とがある。今回我々は, Parallel graft techniqueを用いて治療 し比較的良好な結果を得たため，その有用性を報告する。

【症例】79歳男性

【既往歴】腹部大動脈瘤に対する人工血管置換術後 術後対麻瘏 腹壁㓔痕ヘルニア心不全 (EF31\%)

【現病歴】腹部大動脈瘤手術時に傍腎動脈腹部大動脈瘤 $40 \mathrm{~mm}$ を 伴う, 腹部大動脈瘤, 腸骨動脈瘤に対し, 開腹瘤切除, 人工血 管置換術が施行された。8年後心不全にて当院救急搬送され際, 傍腎動脈腹部大動脈瘤 $80 \mathrm{~mm}$ が指摘された。

【手術方法】EVARはGore Excluder, Chimney 法, pericope 法 にはGore VBXを使用した。術後CTにて endoleak type2および 3が指摘され，再手術を施行した。Main bodyとVBX間に生じ たgutterを経由し瘤内にカニュレーション後, 下腸間膜動脈, 腰動脈および瘤内を可及的にコイル塞栓した。しかし Type3が 残存し再々手術となった。左腎動脈に挿入されたVBX, Aorta Extention 追加延長し, 腹部大動脈に突出しているVBX ステ ントを過拡張させたのち, Aorta Extentionをballoon 拡張させ た (eye of the tiger 法)。術後造影CTにて endoleakが消失した。 Key words : endovascular aortic repair, gutter leak

\section{0-10-3 破裂性傍腎動脈型腹部大動脈瘤に対する chimney EVARの適応拡大 -早期・中期成績をopen surgical repairと比較して-}

山口大学 血管外科

森景則保, 溝口高弘, 永瀬 隆, 竹内由利子, 佐村 誠, 原田剛佑, 未廣晃太郎, 濱野公一

破裂性腹部大動脈瘤（RAAA）に対するEVARは適切な工夫に より, 循環動態や解剖学的条件に関係なく open surgical repair （OSR）より良好な成績が得られることを報告してきた。また， 傍腎動脈型腹部大動脈瘤（JAAA）に対する chimney EVAR (chEVAR) の有用性も報告しており, 今回は破裂性傍腎動脈型 腹部大動脈瘤（RJAAA）に対する chEVARの適応拡大につい て検証した。

【対象と方法】2005年から2020年4月に同一術者によるRAAA 87 例 (EVAR 56例, OSR 31例) のうち, RJAAA 11例（chEVAR 6例，腎動脈上遮断を要したOSR 5例）を対象とした。中枢ネッ ク長 $(\mathrm{mm})$ は chEVAR $5.2 \pm 5.4$ vs. OSR $6.0 \pm 3.8$ あり（p= 0.78），他の背景因子も同等であった。chEVARはEndurant 5 例, Excluder 1例, single chimney と double chimney が各々3例 であった。chEVARの4例に瘤内塞栓（NBCA+lipiodol）を施行 した。観察期間（月）はchEVAR $22 \pm 17$ vs. OSR 50土26であり 
$(\mathrm{p}=0.07)$, 両群で来院から手術開始・グラフト完成時間, 術後合 併症, 在院死亡, 入院期間, 遠隔期瘤関連死亡について検討した。 【結果】来院から手術開始・グラフト完成 (chEVAR vs. OSR, 分）はそれぞれ $44 \pm 22$ vs. $151 \pm 49,132 \pm 65$ vs. $430 \pm 120$ であっ た（ $\mathrm{p}=0.003,0.003 ） 。$ 術後合併症は chEVAR 1 例（心筋梗塞・呼 吸不全・腎不全），OSR 2例（LOS, 呼吸不全）であり（ $\mathrm{p}=0.55 ）$ ， ACSは両群とも認めなかった。在院死亡はLOSによるOSR1例 のみであった $(\mathrm{p}=0.45)$ 。在院日数（日）はchEVAR $16 \pm 10$ vs.

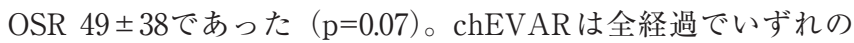
エンドリークもなかった。両群とも遠隔期瘤関連死亡はなかった。 【結語】RJAAAに対する chEVARはOSR と同等以上の早期・ 中期成績が得られることが示唆された。

Key words : ruptured juxtarenal AAA, chimney EVAR

\section{0-10-4 中枢側IFU外症例に対するfenestrated EVAR、chimney EVARの初期中期成績}

${ }^{1}$ 金沢大学 心藏血管外科, ${ }^{2}$ 金沢大学 放射線科 ○木村圭一 ${ }^{1}$, 上田秀保 ${ }^{1}$, 齋藤直毅 ${ }^{1}$, 鷹合真太郎 ${ }^{1}$, 山本宜孝 ${ }^{1}$, 扇 尚弘 ${ }^{2}$, 飯野賢治 ${ }^{1}$, 竹村博文 ${ }^{1}$

【はじめに】EVARの適応拡大に伴い, 中枢側 IFU外（short neck, severe angulated neck, reversed taper) 症例に対して fenestrated EVAR (FEVAR) や chimney EVAR (ChEVAR) が施行されている。当科では, 開腹手術困難症例に限り FEVAR やChEVARを施行しており，その成績を報告する。

【対象】2017年7月から2019年12月までに, FEVARまたは ChEVARを施行した13例（緊急2例を含む），男女比 10:3，平均 年齢73.3(56-94) 歳を対象とした。

【結果】FEVARまたはChEVAR施行理由として, 中枢ネック (PN) $10 \mathrm{~mm}$ 未満: 8 例 (平均 $6.0 \mathrm{~mm}$ ), reversed taper $+\mathrm{PN}$ $15 \mathrm{~mm}$ 未満 : 2 例, 性状不良 (血栓, ULP) : 2例, 高度屈曲 : 1 例であった。メインデバイスとしてEndurant 10例, Zenith 1例, AFX 1例に用い, FEVARを6例（両側1, 片側 4, 片側 +SMA 1), ChEVARを5例（両側2，片側 3)，FEVAR + ChEVARを2例に 施行した。手術時間は平均181.2（82-349）分, technical success は100\%で,術中 type Ia エンドリーク（EL）を3例に認めたが, 僅かであり追加治療は行わなかった。術中・早期合併症として, 腎動脈損傷 1 例, 狭心症 1 例, 腎動脈狭窄 1 例, 中期成績としてメ インボディの migrationによる腎動脈閉塞を 1 例に認めた。腎動 脈狭窄・閉塞症例はいずれも FEVAR症例であった。術後CTに てType Ia ELは全例消失, type II ELは2例に認めた。 $5 \mathrm{~mm}$ 以 上の瘤径縮小は6例に得られ，7例は不変, 増大症例は認めてい ない。

【結語】FEVARに際しては腎動脈ステント留置を併施するなど の改善が必要と考えられた。当科におけるFEVAR/ChEVARの 初期中期成績は概ね良好であり, 同術式の適応拡大は可能と考 えられた。

Key words : chimney EVAR, fenestrated EVAR

\section{0-10-5 演題取下げ}

\section{0-11-1 大動脈ステントグラフト内挿術患者における尿中 NGALを用いた術後急性腎障害診断の新たな兆し}

久留米大学 外科

○大塚裕之，鬼塚誠二，高瀬谷徹，中村英司，新谷悠介， 姉川朋行, 音琴真也, 廣松伸一, 田山栄基

【背景】大動脈瘤に対するステントグラフト内㨂術は，従来の人 工血管置換術と比べ低侵襲であるが，術中の放射線被爆や造影 郕による術後腎機能障害が問題である。術後急性腎障害（acute kidney injury:AKI）は，術後の生命予後を脅かす病態であるこ とが明らかとなり，近年ヒト好中球分泌顆粒から分泌された蛋 白である Neutrophil gelatinase-associated lipocalin (NGAL) は AKIを早期に高い確率で予測できる優れたマーカーとして期待 されている。

【目的】今回われわれは，大動脈ステントグラフト内插術治療患 者の術前・術後尿中NGAL 值の推移を検討した。

【対象と方法】2018年7月から2019年12月までに当院で大動脈下 テントグラフト内挿術治療患者50例中，緊急手術および慢性腎 不全患者を除外した47例を対象とした。術式の内訳は, 胸部大 動脈ステントグラフト内插術（TEVAR）は15例，腹部大動脈 ステントグラフト内㨂術（EVAR）は32例。尿中NGAL值は, 術前 (pre), 術直後 (post), 術後2日目 (post2), 術後7日目 （post7）に測定した。

【結果】平均年齢は75.4歳 (63-90), 男性/女性：39/8, 術中造

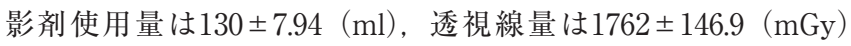
であった。pre-NGAL / post-NGAL / post2-NGAL / post7NGAL:24.9 $\pm 4.5 \mathrm{ng} / \mathrm{ml} / 74.3 \pm 25.8 \mathrm{ng} / \mathrm{ml} / 50 \pm 7.9 \mathrm{ng} / \mathrm{ml} /$ $47.3 \pm 11.2 \mathrm{ng} / \mathrm{ml}$ と術直後が最も高值となり徐々に低下傾向を認 めた。

【考察】尿中NGAL 值は術直後より著明に増加し，術後7日目ま で術前値より高い值を示した。

【結語】尿中NGAL 值は大動脈ステントグラフト内挿術患者の術 後AKIを早期に予測する有用な指標となる可能性が示唆された。 今後, 術後長期にわたる腎機能の推移を含めた詳細な検討が必 要である。

Key words : NGAL, EVAR

\section{0-11-2 腹部大動脈単純遮断に対する好中球ゼラチナー ゼ結合性リポカリン (NGAL) による急性腎障害 (AKI) の早期診断}

\section{久留米大学 外科学講座}

○姉川朋行, 廣松伸一, 音琴真也, 押領司篤宣, 新谷悠介, 中村英司, 大塚裕之, 高瀬谷徹, 鬼塚誠二, 田山栄基 腹部大動脈瘤手術における腹部大動脈単純遮断が腎機能に与 える影響を,腎障害初期で血漿や尿中で濃度が顕著に上昇す る好中球ゼラチナーゼ結合性リポカリン（NGAL; Neutrophil Gelatinase-Associated Lipocalin) を測定し検討した。(対象) 2018年6月から 2020 年4月までに行った開腹下腹部大動脈瘤手術 は32例で, 透析症例の1例を除いた31例中, 術前より NGAL高 值を示した3例（前立腺肥大や尿管結石などの処置を受けていた 症例）を除いた28例を対象とした。腎動脈下遮断21例をI群（平 
均年齢 $69.0 \pm 8.2$ 歳, 男性 17 例, 女性 4 例), 腎動脈上遮断群7例を $\mathrm{S}$ 群（平均年齢73.4 \pm 6.2 歳，男性 4 例，女性 3 例）とし2群の尿 中NGALおよび血清Cre 值を継時的に検討した。(結果) I群 vsS 群において大動脈瘤最大短径は $51.8 \pm 8.8 \mathrm{~m} \mathrm{~m}$ vs. $58.1 \pm 9.9 \mathrm{~mm}$, 手術時間は $279 \pm 64 \mathrm{~min} v \mathrm{vs} .311 \pm 14 \mathrm{~min}$, 大動脈遮断時間は69 $15 \mathrm{~min}$ vs. $75 \pm 15 \mathrm{~min}$, 出血量は $1827 \pm 996 \mathrm{ml}$ vs. $1654 \pm 416 \mathrm{ml}$ であり手術時間のみ有意差（P=0.0414）を認めた。また，術前 の尿中 NGAL は $16.5 \pm 11.3 \mathrm{ng} / \mathrm{ml}$ vs. $11.9 \pm 4.8 \mathrm{ng} / \mathrm{ml}$, 術前血 清 Cre 值 $0.86 \pm 0.21 \mathrm{mg} / \mathrm{dl}$ vs. $1.01 \pm 0.21 \mathrm{mg} / \mathrm{dl}$ と有意差はな かった。術前に対する術後48時間および術後 1 週間のそれぞれ の值の変化に関しては, NGALは術後48時間および1週間に有 意にS 群において值が増加したが, 血清クレアチニン值は 1 週 間目だけ有意にS 群において值が変動していた。(結論) 今回, 腎動脈上遮断において AKIを起こした症例はなかったが，尿中 NGALが血清Cre值よりも早期に上昇した。今後は症例を重ねて, 腹部大動脈単純遮断と腎機能の関係や AKIの早期診断における 尿中NGAL測定の有用性について検討していきたいと考えた。 Key words : NGAL, AAA

\section{0-11-3 腹部ステントグラフト内挿術後の腎機能低下と 凝固系マーカーの関連}

埼玉医科大学 総合医療センター 血管外科

$\bigcirc$ 須原正光，松浦壮平，橋本拓弥，出口順夫

【背景】ステントグラフト内挿術（EVAR）後は凝固系マーカー の異常が遷延することが知られているが，実際の臨床アウトカ ムとの関連は報告が少ない。

【方法】2015年から2018年の4年間に施行された初回 EVAR症 例のうち，術前より血液透析を施行していた 9 例を除く118例 を retrospectiveに検討した。腎機能低下は，既報に則り推定 糸球体濾過量 $(\mathrm{eGFR}) 15 \mathrm{~mL} / \mathrm{min} / 1.73 \mathrm{~m}^{2}$ 以上の低下, $10 \mathrm{~mL} /$ $\mathrm{min} / 1.73 \mathrm{~m}^{2}$ 未満への低下もしくは新規透析導入と定義した。

【結果】追跡期間の平均は26.8 15.0 (0-60) ケ月であった。25 例が腎機能低下をきたし，うち 1 例が透析導入されていた。腎 機能低下までの期間は中央值で4（0-41）ヶ月であった。腎機能 低下群・非低下群で造影剤使用量に有意差はなかった（102.6 $\pm 12.6 \cdot 105.5 \pm 6.8 \mathrm{~mL}, p=0.84 ）$ が，術前 $\mathrm{eGFR}$ が腎機能低下 群で有意に高かった $\left(68.0 \pm 3.7 \cdot 55.5 \pm 1.9 \mathrm{~mL} / \mathrm{min} / 1.73 \mathrm{~m}^{2}, p=\right.$ $0.003)$ 。

術後最新の凝固系マーカーは，フィブリノゲン $325.2 \pm 23.9$. $337.7 \pm 12.9 \mathrm{mg} / \mathrm{dL}, \quad F D P 27.1 \pm 3.9 \cdot 17.5 \pm 2.2 \mu \mathrm{g} / \mathrm{mL}, \quad \mathrm{D}-\mathrm{D}$ $11.4 \pm 1.7 \cdot 8.3 \pm 0.9 \mu \mathrm{g} / \mathrm{mL}, \quad$ PIC $2.2 \pm 0.4 \cdot 1.7 \pm 0.2 \mu \mathrm{g} / \mathrm{mL}$, TAT $8.4 \pm 1.6 \cdot 6.5 \pm 0.8 \mathrm{ng} / \mathrm{mL}$ (平均土標準誤差 それぞれ腎機 能低下群・非低下群の順）であり，FDPが腎機能低下群で有意 に高かった $(p=0.03)$ 。

【考察】FDP高值と腎機能低下の因果関係については言及できな いが，凝固障害が術後腎機能と関連する可能性があり，更なる 検討が望まれる。

Key words : EVAR, coagulation disorder

\section{0-11-4 EVAR後の患者におけるlate open conversionの早期成績}

水戸済生会総合病院 心臓血管外科

$\bigcirc$ 三富樹郷，梅澤麻以子, 倉持雅已, 篠永真弓, 倉岡節夫 【背景】EVAR後の特有の合併症としてエンドリーク（EL）が ある。EL type2は拡大が進行する症例もあり, カテーテル治療 が有効であると報告されている。さらに拡大の進行を阻止でき ない場合はopen conversionを行った症例も報告されている。今 回, 当院で行ったlate open conversionの早期成績について報告 する。

【対象】当院で2010年7月から2018年12月までにEVARを行った 患者は275例であった。そのうち26例にEL type2に対してカテー テル治療を行った。26例のうち4例は拡大が進行したため open conversionを行った。また1例はカテーテル治療を希望せず open conversionを希望した。open conversionを行った5例（1.8\%） を対象とした。

【手術方法】 open conversionは腹部正中切開アプローチで行っ た。大動脈瘤中枢側をクランプできるように大動脈を露出し， 全身へパリン化した後に瘤を縦切開した。ステントグラフトが 逸脱しないように注意しながら瘤内血栓を可能な限り摘除した。 ELの原因となりうる血管を全て縫合止血もしくは焼灼し, 瘤壁 を連続縫合で縫縮した。

【結果】年齢 75 (65-88) 歳, 全て男性。EVAR施行前の瘤径50 (42-64） mmであった。EVAR後1週間目のCTでは3例（60\%） にEL type2を認めた。open conversion施行前の瘤径71（50-82） mmであった。open conversion は EVAR後71（50-82）ヶ月目 に行った。緊急手術は無かった。手術時間は83（68-111）分で あり，術後1週間のCTは44（41-57） mmとなった。術後の合併 症は無かった。open conversion後 3（2-7）ヶ月の瘤径は40（3447） $\mathrm{mm}$ であり，さらなる縮小を来していた。

【結語】 EL type2による瘤径拡大に対する open conversionの短 期成績は良好であった。

Key words : EVAR, open conversion

\section{0-11-5 EVAR術後遠隔期に起きたtype3bエンドリーク による腹部大動脈破裂の 1 例}

勤医協中央病院 心臓血管外科

○南田大朗, 原田裕輔, 山川智士

腹部大動脈瘤に対するステントグラフト内挿術後の瘤破裂の発 生率は $0.6 \%$ 死亡率は $38 \%$ と報告されているが,グラフト損傷によ る type $3 \mathrm{~b}$ エンドリークの報告は稀である。今回我々は,腹部ス テントグラフト内挿術後遠隔期にtype $3 b$ エンドリークによって 瘤が破裂した症例を経験したので報告する。症例は60歳,男性。 57 歳時に最大径 $55 \mathrm{~mm}$ の腎動脈下腹部大動脈瘤に対して EVAR を施行した。術後エンドリークを認めず瘤拡大なく経過してい たが3年半後に突然の腹痛を認め, 救急搬送された。搬入時 CTに て Fitzgerald分類3型の腹部大動脈破裂およびステントグラフト のメインボディ背側からのtype3エンドリークを認め, 瘤の最大 短径は $61 \mathrm{~mm}$ であった。3ヶ月前のCTでは最大短径 $56 \mathrm{~mm}$ で瘤 拡大を認めていなかった。緊急でEVAR（アオルタカフ抻入） 
を施行し造影剂漏出は消失した。術後貧血の進行, 腹部症状なく 経過していたが術後 CTで瘤拡大および後腹膜血腫の増大を認め た。明らかな瘤内への造影剂漏出は同定できなかったが破裂孔 を介してエンドリークが残存していると判断し,術後11日目に人 工血管置換術,ステントグラフト抜去を施行した。瘤を切開する とグラフト自体からの出血はなく腰動脈からの出血を1箇所認め 縫縮止血した。術後経過では麻㿎性イレウスを認めたが保存的 治療で改善し術後23日目に自宅退院となった。抜去した初回ス テントグラフトはメインボディ背側のファブリックに $2 \mathrm{~mm}$ ほど の亀裂を認めており,type3b エンドリークおよび大動脈破裂の原 因と考えられた。

Key words : type3b endleak, late aneurysm rupture

\section{0-12-1 EVAR後潜在性エンドリークに対するoverhaul conceptの臨床的有用性の検証}

${ }^{1}$ 聖マリアンナ医科大学 放射線医学講座, ${ }^{2}$ 聖マリアンナ 医科大学 心臟血管外科学

○小川普久 ${ }^{1}$, 西巻 博 $^{2}$, 千葉 清 $^{2}$, 小德暁生 ${ }^{1}$, 丸橋孝昭 ${ }^{2}$, 八木橋国博 ${ }^{1}$, 三村秀文 ${ }^{1}$, 宮入 剛 ${ }^{2}$

背景：EVAR後の瘤径拡大を伴うエンドリーク（EL）の中には, 複数のタイプが混在したものや潜在性のものが一定頻度で存在 し, 追加治療による制御が困難な一因となっている。我々は, overhaul concept と称する, 難治例に対してこれらの可能性を 意識した画像的検索ならびに予防的も含めた追加治療を施行し ている。目的：当院におけるoverhaul conceptの臨床的有用性 について検証した。方法：対象は，2017年7月から2019年12月ま でにEndurantまたはAorfixにてEVARが施行され，術後に瘤 径拡大を呈し, タイプ2ELに対する治療後 (5例)，タイプ3b EL （1例）あるいは分類不能（5 例）または ELの同定が困難（1例） な12例（平均83歳，男性10例）である。平均瘤径は，EVAR前 $53 \mathrm{~mm}$, 追加治療前 $65 \mathrm{~mm}$ で, 追加治療までは平均1659日であっ た。全例で潜在性タイプ3bELを意識し endograft relining を施 行した。術中の選択造影でタイプ1またはタイプ2ELを認めた場 合は, 追加ステントグラフト留置または塞栓術を施行した。結 果：1例を除いて予定手技に成功した。術中合併症は認めなかっ た。4例で術中造影にてタイプ1EL（1a: 1例，1b: 3例）を認め, 追加治療を要した。分類不能EL 5 例のうち4例はELが残存した。 平均観察期間は328日で, 2例死亡し1例は瘤破裂が原因であった。 8例（67\%）は瘤拡大の停止が得られている。結語：Overhaul concept は難治性の瘤径拡大に対して有用な手法となり得る。し かし, 分類不能型 $\mathrm{EL}$ は本手法に扔いても制御困難であり, 本手 法後も瘤径拡大を示す場合は開腹手術への移行を検討すべきで ある。

Key words : overhaul concept, occult endoleak

\section{0-12-2 EVAR術前予防的大動脈分枝塞栓術：タイプ2 エンドリークと瘤径变化に関する検討}

${ }^{1}$ 日本医科大学 付属病院 放射線科, ${ }^{2}$ 日本医科大学 付 属病院 心臟血管外科

○上田達夫 ${ }^{1}$, 小谷映午 ${ }^{1}$, 斉藤英正 ${ }^{1}$,

杉原史恵 ${ }^{1}$, 安井大祐 ${ }^{1}$, 白井清香 ${ }^{1}$, 藤綱隆太朗 ${ }^{1}$,

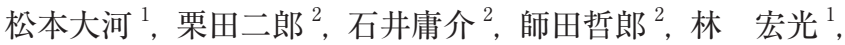
汲田伸一郎 ${ }^{1}$

【目的】EVAR術前予防的大動脈分枝塞栓術がタイプ2エンドリー ク（T2EL）発生と瘤径変化に与える影響に関して後ろ向きに検 討する。

【方法】2018年2月～2019年8月の間にEVAR術前予防的大動脈分 枝塞栓術を施行した 24 例（平均年齢: $81.4 \pm 6.2$ 歳，男/女: 17/8) を塞栓群（EG; Embolization Group）とした。塞栓対象は下腸 間膜動脈，左右第 $2 \sim 4$ 腰動脈，正中仙骨動脈のうち起始部が開 存している径 $2 \mathrm{~mm}$ 以上の血管とした。一方，2016年1月～2018 年1月の間に予防的大動脈分枝塞栓術を施行しなかった19例 （平均年齢: $79.0 \pm 6.4$ 歳，男/女:14/5）を対照群（CG; Control Group）とした。EVAR直後，1，3，6，12 ケ月後にCTを施行し， $\mathrm{EG}$ と CGに扔ける T2EL発生率, 瘤径変化, 瘤径縮小率の比較 を行った。

【結果】2群間の年齢，性別，術前瘤径に有意差は認めなかった。 $\mathrm{EG}$ に抢ける塞栓血管本数は平均 $3.7 \pm 1.6$ 本, 術前より起始部が 閉塞していた血管本数は平均 $1.9 \pm 1.8$ 本であり，両者を合わせる と平均 $5.5 \pm 1.1$ 本の血管が $\mathrm{EVAR}$ 時に閉塞していた。 EVAR直 後，1，3，6，12ヶ月後に打ける EG/CGの T2EL 発生率（\%）は 8.3/21.1，12.5/26.3，4.2/21.1，10.0/31.6，9.1/26.3であった。有 意差は認めないものの全期間に扔いて EGはCGよりも T2EL発 生率が低かった。一方，1，3，6，12ケ月後に打ける $\mathrm{EG} / \mathrm{CG}$ の 瘤径変化 $(\mathrm{mm})$ は-0.9/-0.3，-2.4/-0.7，-5.0/-2.3，-8.4/-3.6（いず れも $\mathrm{p}<0.05 ） て ゙ あ り ，$ 瘤径縮小率（\%）は-1.8/+0.6，-4.9/-1.1, $-10.0 /-3.9 ，-17.0 /-6.4$ (いずれも $\mathrm{p}<0.05$ ）であった。全期間にお いて EGは CGよりも瘤径変化及び瘤径縮小率が有意に大きかっ た。

【結語】 EVAR術前予防的大動脈分枝塞栓術は T2EL 発生を抑制 し瘤径縮小を促進させる可能性が示唆された。

Key words : EVAR, type 2 endoleak

\section{0-12-3 エンドリークゼロを目指して - 術中腰動眽塞栓 導入と初期成績}

一宮市立市民病院 血管外科

○小山明男，森前博文，松下昌裕

EVAR 後の Type2EL は瘤径拡大の危険因子であり, 術中 IMA 塞栓はEL予防の一般的な手技となってきている。しかし術 中腰動脈塞栓に関してはIMA 塞栓に比べ難解であり, 且つ手 技・対応の是非について未解決の課題である。しかし腰動脈に よる Type2ELは一旦再治療となると治療に難渋することも多 く, 当科では2019年1月より術中IMA 塞栓に加元腰動脈塞栓も できる限り行う方針とした。2019年1月より2020年5月までに EVAR 症例の内21例に術中腰動脈塞栓を施行した。メインデバ 
イスは Endurant:12例・AFX2:7例・Zenith:2例であった。4例 （19\%）で内腸骨動脈塞栓・16例（76\%）でIMA 塞栓も施行し た。当科の腰動脈塞栓の基本手技は6FrDestination backup下に RDC（もしくはAL1）で腰動脈根部を選択し, Breakthrough・ CHIKAIVで腰動脈末梢を選択し0.018タイプの電気式・プッシャ ブルコイルを組み合わせて塞栓している。平均腰動脈塞栓は 2.1 本（1-6本）であった。退院前 CTでは15例（71\%）はエンドリー クを認めず, L4腰動脈1対（2本）塞栓できた6例は全例でエンド リークを認めなかった。半年後のCTでは瘤径拡大している症例 はなかった。最近では手技も安定してきており, ほとんどの症 例で予定した腰動脈をすべて塞栓できている。術中腰動脈塞栓 は手技だけでなく, 術前プランニングも重要でありあわせて供 覧する。

Key words : AAA, TAE

\section{0-13-1＼cjkstart腹部ステントグラフト留置後の瘤体積と Aneurysm wall enhancement值は相関する}

東京大学医学部附属病院 血管外科

○大片慎也, 保科克行, 露木翔太, 遠藤貴士, 前野竟平, 花田和正, 大橋雄一, 佐野允哉, 宮原和洋, 福原菜摘, 赤井隆文，松倉 満，伊佐治寿彦，高山利夫

【目的】腹部大動脈ステントグラフト (EVAR) 留置前後の瘤 体積と最大短径スライスにおける瘤壁全体の Aneurysm wall enhancement (AWE) を評価した。瘤体積の変化と AWE值の 相関を解析し, また AWEを術直後と術後半年との 2 点で評価 することで，時間経過による AWEの変化も解析した。

【方法】2009年から2018年までに東京大学血管外科で施行された EVAR症例のうち, 術後に造影 $\mathrm{CT}$ を撮像された 28 例を後方視 的に評価した。瘤体積とAWEの計測にはOsirix Dicom Viewer を用いた。瘤体積は瘤の中枢から末梢までを積分して計測し， 術前と直近でのフォローとの 2 点を用い術前後の瘤体積比を計 算した。AWEは最大短径部のスライスにおいて, 瘤壁全体を CT 值でvolumetryを行いその值を求めた。術直後と術後半年の 2 点で計測し, AWEと瘤体積比との相関を術直後の AWEと術 後半年の AWEとでそれぞれ計算した。

【結果】瘤体積変化と術後半年以上経過した時点での AWEとの 間には強い相関が見られたが, 瘤体積変化と術直後の AWEと の間には弱い相関しか見られなかった。

【結論】瘤体積変化と AWEとの間には相関関係が見られ, 時間 経過とともに相関が強くなると考えられた。

Key words : Post-EVAR Aneurysmal change, Aneurysm wall enhancement

\section{0-13-2 Complex EVARにおける 3Dモデルを使用した 手技のシミュレーション}

静岡市立静岡病院 心臓血管外科

$\bigcirc$ 三岡 博, 寺井泰彦, 宮野雄太, 内藤豊貴, 田内淳介, 山崎文郎

【目的】FEVAR（開空型EVAR）, chEVAR（chimney法）, RIBS (retrograde in situ branched stent graft) は頭頸部および内臓
分枝温存の観点から IFU内ステントグラフト手技ができない場 合のハイリスク大動脈瘤症例における重要な rescue 手技である。 これらの手技に共通するのは周到な術前の準備が必要なことで あり，手技選択 (FEVARかchEVAR), FEVARにおける分枝 開空の設計, chEVAR手技におけるtype3EL（endoleak）の回 避のみならず, 特に複雑な RIBSのような手技においてはチーム 全員での手技の理解も含まれる。当院ではこれらの手技に対す る3D modelを使用したシミュレーションを2019年4月より開始 し良好な成績をえており，その有用性について報告する。

【方法】3Dモデルは各症例のCTの DICOM dataから Mimics inPrint 3.0 (Materialise NV, Leuven, Belgium) を使用してSTL ファイルを作成し, クリア光重合レジンを使用し3D printer (Form 2, Formlabs Inc., MA, USA) で出力。 juxta-renal AAA の FEVAR6 症 例, "eye-of-the-tiger" molding 法をもちいた chEVAR 2 例, Z2 TEVAR後のSINEによる弓部慢性破裂症例 の3D model を出力し, 術前 simulationを行なった。

【結果】FEVAR6症例における fenestration mismatchはなかっ た。FEVARが不適と判断されたchEVAR 2 症例はgutter leak の発生はなかった。弓部慢性破裂症例は選択的脳分離循環下 に carotid-carotid bypass とZ0 TEVARを施行して第一分枝の RIBS を行ない, endoleakや脳梗塞は発生せず救命と瘤縮小をえ た。

【結論】CTのDICOM dataを使用した3D modelとそれを使用し た simulationはFEVARの分枝開空の設計, chEVAR手技にお ける type3ELの回避, RIBSに扔ける複雑な手技のチーム内での 共有に極めて有用であった。

Key words : 3D printer, fenestration

\section{0-13-3 ステントグラフト内挿術 (EVAR) に伴う内腸骨 動眽（IIA）塞栓後の殽筋跛行の予後と血管機能の関連に ついての検討}

東北大学病院 総合外科

○鈴木峻也, 後藤 均, 赤松大二朗,

菅原宏文, 吉田良太朗, 田島悠太, 堀井晋一良, 高橋宏和, 小笠原紀信, 長岡洋平, 亀井 尚

背景:EVARに伴う IIA 塞栓は広く行われている手技であるが, 術後の臂筋跛行によるQOLの低下が問題となる。同様に跛行 を呈する下肢PADにおいて, その重症度と血管機能の関連性 が報告されている。上腕動脈における血流依存性血管拡張反応 （FMD）とニトログリセリン依存性血管拡張反応（NMD）はそ れぞれ血管内皮・平滑筋機能の指標であり, 全身の血管機能を 表しているとされる。IIA 塞栓後をIIAにおけるPAD と近似し ている状態と想定し, 臂筋跛行の予後と血管機能の関連性につ いて前向きに検討した。方法:EVAR予定患者のうちIIA 塞检を 併施する者を対象とした。入院後にFMD/NMDの計測を行っ た。術前と術後1週間, および術後6ヶ月まで毎月6分間歩行試験 (6MWT) を行い, 跛行の有無, 最大歩行距離 (MWD) を調査 した。各回の跛行出現例と非出現例で血管機能を比較した。結 果：13例を検討し, 平均年齢は $78 \pm 4.3$ 歳で全て男性であった。 $\% \mathrm{FMD} / \% \mathrm{NMD}$ の平均は $4.4 \pm 3.1 / 15.4 \pm 7.0$ であった。術後1週間 
の6MWTにおいて12例の跛行を認め, 以後漸減した（1か月:11例, 2か月:7例，3か月:6例，4か月:5例， 5，6か月:4例)。各期間での 跛行出現例と非出現例の血管機能を比較したところ, FMDでは 術後1，2，5，6か月で（2.7[1.9-5.6]vs9.25[8.5-10] p=0.05, 1.9[1.3-3.1] vs7.1[2.7-9.0] $\mathrm{p}=0.02,1.9[1.2-2.8] \mathrm{v} 55.6[2.7-8.6] \mathrm{p}=0.06$, 同), NMD では術後1，5，6か月で（13.2[8.6-18.2]vs23.9[23.6-24.1] p=0.08， 8.1[6.5-15.8]vs17.8[11.6-23.9] p=0.05, 同）低值もしくはその傾向に あった。結論：血管機能の低下が，臀筋跛行を遷延させる可能 性が示唆された。この結果は術前にIIA 再建を検討する一助と なる可能性がある。

Key words : EVAR, FMD

\section{0-13-4 IMPEDEを用いて内腸骨動脈を塞栓しEVARを 施行した 1 例}

琉球大学大学院 医学研究科 胸部心臓血管外科学講座 ○比嘉章太郎, 永野貴昭, 上門あきの, 安藤美月, 前田達也, 喜瀬勇也, 稲福 斉, 仲栄真盛保, 山城 聡 【はじめに】これまでType2エンドリーク予防のため使用され る塞栓物質としては，プラグやコイルなどが一般的である。し かしプラグでは再疎通が多いとの報告や，コイル塞栓ではコイ ルの本数を使用するため, コストの問題が生じている。新た な塞栓物質として近年注目されているShape memory polymer （SMP）があり，2020年2月より使用可能となったIMPEDEは， SMPを用いた本邦初のデバイスである。今回 IMPEDEを用いて 内腸骨動脈塞栓術の初期経験を報告する。

【症例】5年前に左内腸骨動脈瘤に対して当院にて腸骨動脈ステ ントグラフト+右内腸骨動脈コイル塞栓施行歴のある 82 歳男性。 定期的にCTフォロー中であったが，経過で右内腸骨動脈瘤の 拡大を認めたため，手術予定となった。全身麻酔下に左FAよ り経皮的に $6 \mathrm{Fr}$ シースを扱入し， $5 \mathrm{Fr}$ 造影用カテーテルを右内腸 骨動脈へ留置した後，ガイドワイヤーをRosen Curved ガイドワ イヤーへ交換した。続いて6Frガイディングシースを挿入した。 その後IMPEDE（IMP-10）を挿入し，上殿動脈へ留置した。続 いて下殿動脈へアプローチし，同様にIMPEDE（IMP-10）を挿 入, 留置した。続いてFAアプローチにてExcluderの脚を挿入し, 大動脈分岐部直下から展開した。最終造影でエンドリークがな いことを確認して終了とした。フォローのCTでは明らかなエン ドリークは認めなかった。またアーチファクトが少ないことか ら瘤内評価が容易であった。

【結語】今回本邦で使用可能となったIMPEDEに関する初期経 験を報告した。コイル使用時と確認造影の方法・タイミングを 変えるなどの工夫は必要であるが, 術後のエンドリークの評価 がしやすいこと，初期の塞栓効果が高いことが示唆された。

Key words : Endovascular treatment, Shape memory polymer
0-14-1 鼠径部処置後の感染性総大腿動脈仮性瘤破裂に 対して、人工血管を使用し対側総大腿動脈一同側膝窩動脈 ハイパスを行った 4 例

岸和田徳洲会病院

○平松範彦, 畔柳智司, 降矢温一, 小島三郎, 松浦 誠, 春日健介, 竹本哲志, 小林将明, 石堂耕平, 東上震一

【はじめに】稀ではあるが，鼠径部の処置後に感染が生じ，総大 腿動脈に感染性仮性瘤を形成することがある。総大腿動脈に感 染性仮性瘤を生じ，破裂に至った症例に対し，人工血管を用い て対側大腿動脈から大腿内側を経由し, 膝窝動脈へのバイパス を行った症例を4例経験したので報告する。

【症例】症例は67歳女性，75歳女性，82歳男性，84歳女性の4例 であった。感染の原因となった处置はTEVARが2件, EVARが 1 件, $\mathrm{CV}$ カテーテルの長期留置が 1 件であり, 患側は右が 3 件, 左が1件であった。全症例が破裂に伴う出血性ショック下の緊急 手術であり，全身麻酔で行われた。トンネラーを用いて対側鼠 径部から恥骨前面から大腿内側へ皮下トンネルを作成し，人工 血管を使用して対側の総大腿動脈から滕窩動脈へバイパスを行っ ており，患側の総大腿動脈は仮性瘤の前後で結紮閉鎖していた。 また，使用された人工血管はいずれも MAQUET社の FUSION $8 \mathrm{~mm}$ であった。すべての症例で感染創部は解放とし, 術後洗浄 を行い，抗生剂の静脈投与を行っていた。術後の感染コントロー ルは良好であり，全例，解放創はその後退院可能な状態まで治 瘾しており，人工血管感染の兆候も認められなかった。4例中 3 例が術後 1 力月, 術後5力月, 術後16力月で死亡していたが, い ずれも血管系の要因による死亡ではなかった。

【考察】総大腿動脈の感染に対しては，外腸骨動脈から閉鎖孔や 大腿外側を経由するバイパスが用いられることが多いが，手術 操作が多く，手術時間が長くなる傾向にある。本法では感染巣 から人工血管までの距離が十分である必要があるが，有用な方 法の一つであると考える。

Key words : groin infection, femoral artery infection

\section{0-14-2 再建人工血管感染症に対して被覆筋皮弁(MFC) を行った治療経験}

${ }^{1}$ 小倉記念病院 血管外科, ${ }^{2}$ 済生会八幡総合病院 血管外 科, ${ }^{3}$ 製鉄記念八幡病院 血管外科

○田中 潔 $^{1}$, 田中慎一 ${ }^{1}$, 三井信介 ${ }^{2}$, 石田 勝 $^{3}$, 郡谷篤史 ${ }^{2}$, 川久保栄介 ${ }^{2}$, 岡崎 仁 $^{1}$

（背景）血行再建術後合併症のなかでも，人工血管感染症は非常 に重篤なものある。治療法は，至適抗生剤投与を行い，感染グ ラフト除去，他のルートによる再血行再建が第一選択であるこ とは疑う余地もない。しかし，患者の状態により選択をためら う場合がある。その際われわれは, 感染人工血管にMFCを行い 治療してきた。气の治療経験を報告する。(対象と方法）2000/4 より2018/6までに所属3施設にて被覆筋皮弁が行われた，8例（平 均年齢歳 男性7例）を対象とした。創治瘺，感染の再発，グラ フトサルベージ, 大切断回避率, 生存率を Kaplan-Meier 法にて 評価した。(結果) 平均観察期間24ケ月（1-60M）。6例が鼠径部, 2例が大腿部の感染にて MFCを㧍こなった。使用した筋皮弁は 
縫工筋/薄筋が7/1例であった。8例とも一度は創治癒を認めた が，3例は8ケ月以内の再発を認めた。そのうち1例は持続陰圧療 法を行い, 再度創治癒を得たが, 1例はグラフトルートの変更を 余儀なくされ，1例は耐術不可能と考えられ抜去のみを行った。 入院中死亡が 2 例。経過中に大切断はなかった。4例は 2 年以上再 発なく, 生存している（まとめ） MFCは低侵襲で有り，グラフ 卜感染に対して有効な方法です。しかし, 一度創治癒を認めても, 感染再発はいつでも起こりえるため, 厳重なfollowを必要とし ます。

Key words : Muscle flap, graft infection

\section{0-14-3 感染性大腿動脈瘤に対しホモグラフトを用いた 血行再建を施行した 2 例}

東京大学医学部付属病院

○露木翔太, 伊佐治寿彦, 遠藤貴士, 名木田明幸, 前野竜平, 大片慎也, 花田和正, 佐野允哉, 大橋雄一, 福原菜摘, 宮原和洋, 松倉 満, 赤井隆文, 高山利夫, 保科克行

【背景】感染性大腿動脈瘤に対する手術戦略として以前は extraanatomical bypassが標準術式とされていたが, 近年では人工血 管や自家静脈を用いたin situでの血行再建が多く報告されてい る。人工血管は感染の危険性が高く，また自家静脈を使用する 際は口径差のため深部静脈の採取が必要になることが多い。凍 結保存同種組織（ホモグラフト）はこれらの観点から感染性大 腿動脈瘤に対する血行再建に損いて優れた材料である。今回我々 は感染性大腿動脈瘤に対するホモグラフトによる血行再建手術 症例を 2 例経験した。

【症例1】70代男性, MRSAを起因菌とする感染性心内膜炎に対 するBentall 手術後, 右下肢虚血のため浅大腿動脈狭窄に対し DCBを用いた経皮的血管拡張術を施行した。その後同部位に感 染性仮性瘤が出現し, 瘤切除及びホモグラフト置換術を施行した。 ホモグラフトの総大腿動脈, 浅大腿動脈, 大腿深動脈をそれぞ れ宿主の同名動脈に吻合して再建した。術後合併症なく経過し ている。

【症例2】70代女性, MRSAを起因菌とする化膿性右膝関節炎の 加療中に感染性心内膜炎を伴う右大腿動脈感染瘤と診断され, 増大傾向を認めたため準緊急で瘤切除及びホモグラフト置換術 を施行した。腸骨動脈のホモグラフトを利用し，総腸骨動脈， 外腸骨動脈, 内腸骨動脈を, それぞれ宿主の総大腿動脈, 浅大 腿動脈, 大腿深動脈断端に吻合し再建した。術後合併症なく経 過している。

【結語】2例の感染性大腿動脈瘤に対して二又形状のホモグラフ トを利用し血行再建を行った。術前に切除範囲及び再建部位を 検討し, 口径差の少ない適切なホモグラフトを選択することで, 大腿動脈分岐部に対する血行再建を問題なく行うことが可能で あった。

Key words : infectious femoral aneurysm, homograft

\section{0-14-4 鼠径部感染を伴亏総大腿動脈仮性動脈痹に対 し、閉鎖孔バイパスにより治療した 2 例}

富山大学附属病院 第一外科

○山下重幸, 山下昭雄, 長尾兼嗣

鼠径部の感染に伴う総大腿動脈仮性動脈瘤2例を経験し, 動脈修 復 (バイパス) の方法, 感染創の治療について検討した。鼠径 部に感染創がある場合, 迁回するための方法としていくつかの 非解剖学的バイパス術があり, 今回行った閉鎖孔バイパスはそ れらのうち代表的なものである。しかし, 直接閉鎖する場合と 比べて下腹部および大腿部に別に皮膚切開を要し, 閉鎖孔ルー トの確保, グラフトの準備が必要である。1例目は 10 年前の人工 血管バイパス術後の感染に伴う吻合部破綻で, 破綻部の再建は 不能であったため迷うことなく閉鎖孔バイパスを選択した。2例 目は脳神経外科でのカテーテル治療後の穿刺部感染に伴うもので, 動脈欠損孔は小さく $(3 \times 5 \mathrm{~mm})$, 自家静脈パッチによる修復を 選択した。しかし, その後に創部離開し動脈修復部が破綻した ため, 緊急で閉鎖孔バイパス術を行わざるを得なくなった。感 染創部の処置については2例とも可及的に污染組織をデブリード マンし，十分に洗浄した後ドレーン留置し1期的に閉創した。し かし，2例とも創部癒合不良で創下に浸出液貯留し再開創せざる を得なかった。これらのことから, 鼠径部の感染に伴う大腿動 脈仮性動脈瘤では, 同一部位での修復は避けるべきであり, また, 創部の 1 期的閉鎖には十分な注意が必要であると考えられた。

Key words : Obturator bypass, vascular infection

\section{0-14-5 鼠径部動脈感染手術例の長期予後検討}

東京大学 血管外科

○遠藤貴士, 高山利夫, 露木翔太, 前野竜平, 大片慎也, 花田和正, 大橋雄一, 佐野允哉, 福原菜摘, 宮原和洋, 赤井隆文, 松倉 満, 伊佐治寿彦, 保科克行

【背景】鼠径部動脈感染は, 外科手術や大腿動脈穿刺に続発する 合併症のひとつである。治療には癒着剥離, 人工物の除去, 血 行再建など高い侵襲度の手技が要求される。また, 長期予後を 検討している報告は少ない。

【目的】鼠径部動脈感染の長期予後調査から治療戦略を検討する。 【対象と方法】1995年〜2006年に当科で経験した鼠径部動脈感染 症例12例を対象としたカルテ調査により, 診断, 治療法, 起因菌, 術後抗生剂投与期間，転帰等の項目を検討した。

【結果】平均年齢は60.8歳（17-80歳）ですべて男性であった。合 併症は, 糖尿病が1例 (8.3\%), 透析症例が1例 (8.3\%), 悪性腫 瘍が5例（42\%）で，その他高安動脈炎と潰瘍性大腸炎の合併を それぞれ1例 $(8.3 \%)$ ずつ認めた。平均観察期間100.5ヶ月（1.2207 月)。動注ポート感染が4例 (33\%), 人工血管を用いた血 行再建術後の人工血管感染が8例（67\%）であった。全例で人工 物の除去（または部分除去）を施行し, 自家静脈による血行再 建が5例 $(42 \%)$ ，人工血管による血行再建が3例（25\%）であっ た。起因菌を同定できたのが8例 $(67 \%)$ で，そのうち5例が MRSA（うち1例が緑膿菌も検出）, 2例がMSSA, 1例がブドウ球 菌属であった。平均術後抗生剂投与期間は5.8ヶ月（0.1-20ヶ月） で, 感染巣に対する追加手術を要したのは 1 例（8.3\%）であった。 
【結語】鼠径部動脈感染に対する適切な外科的治療で効果的な局 所感染制御が可能であると考えられる。時期を逸さない外科的 治療により, 人工物が残存する症例であっても術後抗生剤投与 期間を縮小できる可能性があると考えられる。

Key words : femoral infection, revascularization

\section{0-14-6 人工凌関節置換術後に発症した膝窝動脈仮性動 眽瘤破裂に対し人工血管置換術を行なった 1 例}

東海大学 医学部 外科学系 心臟血管外科学

○山本克佳, 小田桐重人, 志村信一郎, 岡田公章,

尾澤慶輔, 内記卓斗, 長 泰則

【背景】膝窩動脈瘤は末梢動脈瘤の中では比較的頻度の多い疾患 であるが，そのほとんどは変性による真性動脈瘤であり，半数 以上が症候性で急性閉塞症や破裂にて診断される事が多い。手 術法としては滕窩動脈置換術, バイパス術があり, 到達法も仰 臥位で行う内側到達法と, 腹臥位で行う後方到達法がある。本 症例では, 後方到達法にて ePTFE人工血管を用いた滕窩動脈置 換術を施行し，良好な経過を得た症例を経験したので報告する。 【症例】74歳男性, 数日前より急激に左膝関節の可動域障害, 腫 脤を認めたため前医受診した。精查にて左膝窩動脈の仮性動脈 瘤の診断となり, 加療目的に当院紹介となった。既往歴として, 变形性膝関節症に対して, 半年前に左滕関節人工血管置換術を 施行しリハビリテーション後に自宅退院となっていた。当院 でCT検查したところ左膝関節の仮性動脈瘤㧍よび動脈瘤周囲に 低吸収域を認めた。臨床経過を含めて左滕穸動脈の仮性動脈瘤 破裂の診断で同日緊急手術の方針とした。手術は腹卧位での後 方到達法で行った。膝関節のS 字状切開にて皮切し, 膝窝動脈 を同定した。中枢側 taping したのちに末梢側へ剥離を進め, 仮 性動脈瘤を同定，可及的に瘦孔部を確認した。瘦孔は腹側に位 置しており，エコーと同様，約 $4 \mathrm{~mm}$ の瘦孔を認めた。直接閉鎖 を試みたが，血管壁が非常に脆弱であり，6mm ePTFE人工血 管を用いた人工血管置換術の方針とした。術後経過は良好でリ ハビリ目的に前医へ転院となった。

【結語】膝関節人工関節置換術後に発症した膝窩動脈の仮性動脈 瘤破裂に対して，人工血管置換術を施行した一例を経験した。

Key words : Popliteal aneurysm, Artificial blood vessel

\section{0-15-1 malperfusionを伴う急性A型大動眽解離の治 療戦略}

川崎幸病院 大動脈センター

○栃木秀一

『目的』当センターでは年間150例以上の $\mathrm{A}$ 型解離，50例以上の $\mathrm{B}$ 型解離の入院があり年々増加傾向にある。治療戦略や術式, 術後管理に関しても日々研鑽を重ね徐々に良好な成績となって きており今回，2015年1月から2019年12月の期間に当センターで 治療を行った急性 A 型大動脈解離700例の中でmalperfusion合併 例について検討した。『結果』平均年齢：69歳 (30歳-95歳)，30 日死亡：32例 (4.5\%), 院内死亡：38例 (5.5\%), 自宅退院：457 例 $(65.4 \%)$, 心タンポナーデ合併：96例（13.4\%), 下肢虚血合併： 38例 (5.4\%), SMA 虚血合併：22例（3.1\%), 冠動脈合併：24例
(3.4\%)，脳障害：54例（7.7\%）『考察』手術成績の向上は致死的 となりうる malperfusion（心タンポナーデ・SMA 虚血・冠動脈 虚血・下肢虚血等）合併の治療戦略によるものも大いに貢献し ているように思われる。

Key words : Aortic dissection, malperfusion

\section{0-15-2 Stanford B型慢性解離性大動脈瘤破裂に対す るTEVAR時の偽腔血流の制御}

${ }^{1}$ 名古屋市立東部医療センター心臟血管外科， ${ }^{2}$ 名古屋市立 東部医療センター放射線科, ${ }^{3}$ 名古屋市立大学高度医療教育 研究センター, ${ }^{4}$ 名古屋共立病院放射線科

○水野明宏 ${ }^{1,3}$, 齋藤慈円 ${ }^{1}$, 小川辰士 ${ }^{1}$, 神谷信次 ${ }^{1}$, 武藤昌弘 ${ }^{2}$, 橋爪卓也 ${ }^{4}$, 浅野實樹 ${ }^{1,3}$

【背景】大動脈解離に対する胸部大動脈ステントグラフト内㨂術 （TEVAR）は一般的に行われるようになってきた。一方で慢性 期解離性大動脈瘤破裂に対するTEVARは単独では吹き上がり を制御できず，何らかの偽脘への介入が必要である。今回異な る2つの方法で偽腔血流を制御し救命できた2例を経験したので 報告する。

【症例1】71歳，女性。7年前に $\mathrm{A}$ 型解離に対し上行大動脈人工 血管置換術施行。2 年間は外来通院していたもののdrop out。夕 方からの背部痛で未明に当院 ERへ救急搬送。造影 CTで偽腔 開存型の大動脈解離を認め, 遠位弓部に仮性瘤を呈しており活 動性出血を認めた。残存解離性大動脈瘤破裂と診断し, 緊急で TEVAR（entry 閉鎖）施行。偽腔造影を行うと吹き上がり認め たため，遠位弓部の仮性瘤にNBCAを充填し手技を終了した。 術翌日胸腔ドレナージ施行, 術4日目抜管。術後経過は良好で第 12 病日に退院。術後 2 年経過, 新たな拡大なく過ごされている。 【症例2】85歳，男性。14年前に A 型解離に対し他院にて上行弓 部大動脈人工血管置換術施行。1週間前から胸痛自覚, 咳嗽時に に喀血したため他院へ救急搬送。造影 CT 施行で残存解離性大動 脈瘤破裂を認めた。前医での処置は困難なため当院へ救急搬送。 緊急でTEVAR（entry 閉鎖）施行した。偽晖からの吹き上がり 強く, このままでは循環維持が困難と判断, 腹脉動脈にある reentry vascular plugで挟むように閉鎖。最終造影では偽胿の 吹き上がりは消失し血行動態も安定。当日抜管，第13病日に自 宅退院。現在術後半年経過，偽膑はほぼ血栓化を得られている。 【結語】慢性解離性大動脈瘤破裂に対し entry 閉鎖に加元偽腔血 流制御を行うことで良好な経過を得られたと考える。

Key words : DAA rupture, TEVAR

\section{0-15-3 腹部大動脈瘤に解離が及んだA型解離に対し急 性期人工血管置換術後にYgraft置換術と胸部ステントグラ フト内挿術を同時施行した 2 例}

${ }^{1}$ 上尾中央総合病院 心臓血管外科, ${ }^{2}$ 上尾中央総合病院 放射線診断科

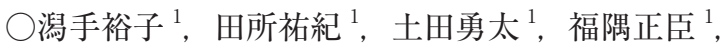
宮内忠雅 ${ }^{1}$, 大竹裕志 ${ }^{1}$, 眞田順一郎 ${ }^{2}$, 手取屋岳夫 ${ }^{1}$ 腹部大動脈瘤（AAA）に及んだ $\mathrm{A}$ 型解離の報告は少ない。今回 我々はAAAに解離が及んだ A 型解離に対して急性期に人工血 
管置換術後, 二期的にYgraft と TEVARを同時に施行した2例を 経験した。症例 $1 ： 75$ 歳男性, 最大短径 $44 \mathrm{~mm}$ (総腸骨動脈径) の AAAを合併するA 型解離とそれに伴うLMT狭窄に対して PCIおよび弓部置換と CABG を施行した。解離は AAA に及び複 雑に三腔解離していたため, 手術に際して右鎖骨下動脈を用い て人工心肺を確立した。術後 3 ケで，解離が及んでいた AAA に対して真腔確保が難しくEVARは困難なため4分枝管を用いた Ygraft置換術を行った。また下行大動脈の真腔が狭小化してお り,リモデリングを期待して同時にTEVARを施行した。腹部 大動脈中枢は真腔に吻合した。末梢は両側外腸骨動脈を先に再 建し，内腸骨動脈用の分枝人工血管を経由してTEVAR（Zenith alpha）を行った。中枢端はElephant trunkにおき, bare stent をYgraft吻合部まで覆うように内挿して真腔を確保した。最後 に内腸骨動脈を再建した。経過は良好で術後 12 日で退院となっ た。症例 $2: 65$ 歳女性, AAAを合併するA型解離に対して弓部 置換を施行した。解離はAAAに及んでおり最大短径は $47 \mathrm{~mm}$ あった。3ケ月後に症例1と同様, Y graft とTEVARを同時に行っ た。経過良好で術後11日で退院となった。両者とも術後合併症 なく経過は良好で，CTでは真腔は拡大し，偽腔の血流は腎動脈 分岐部周辺にのみ残存していた。急性解離術後3ヶ月で, Ygraft 置換術と同時にTEVARを行うことで大動脈のリモデリングを 期待するとともに，真腔の血流を増加し偽腔圧を下げることで Ygraftの中枢吻合を真腔に確実に施行できた症例を経験した。 Key words: Ygraft, TEVAR

\section{0-16-1 B型大動脈解離に対する胸部ステントグラフト内 挿術：慢性晚期症例に対してリエントリー閉鎖追加によるリ モデリング効果の検討}

${ }^{1}$ 関西医科大学附属病院 血管外科, ${ }^{2}$ 関西医科大学附属病

院 心臓血管外科

$\bigcirc$ 深山紀幸 ${ }^{1}$, 善甫宣哉 ${ }^{1}$, 植月友彦 ${ }^{2}$, 桑内慎太郎 ${ }^{2}$, 岡田隆之 ${ }^{2}$, 細野光治 ${ }^{2}$, 金本真也 ${ }^{2}$, 湊 直樹 $^{2}$, 川副浩平 ${ }^{2}$ 【はじめに】 B 型大動脈解離（TBD）に対する胸部ステントグラ フト内挿術（TEVAR）に拈いて，発症4か月以降の慢性晚期に 行った場合, TEVARでは半数にしかリモデリング効果が得ら れないことを報告した。現在では慢性晚期例に対してTEVAR と同時にリエントリー閉鎖を積極的に行っており, 今回その治 療成績を検討した。

【対象】2017年より当院でTEVARを施行したTBDのうち, 破 裂・感染・U L P 症例を除いた偽腔開存症例を対象とした。急 性期・慢性早期（発症4ヶ月以内）例ではTEVARのみ施行した が，慢性晚期例では同時にリエントリー閉鎖も行った。両側腸 骨動脈にリエントリーがある場合は，内腸骨動脈閉塞による合 併症を避けるため，片側のみの閉鎖とした。

【結果】急性期 2 例，慢性早期6例，慢性晚期11例であった。リ工 ントリー閉鎖部位は，腎動脈下腹部大動脈10例，片側腸骨動脈6 例，片側腎動脈根部4例であった。急性期・慢性早期例では全例 でリモデリング効果が得られた。慢性晚期例では8例（73\%）で リモデリングが得られたが，2例（18\%）で5mm 以上の偽腔拡大 を認めた。2例とも両側腸骨動脈にリエントリーがあり，うち1
例では片側のみの閉鎖を行ったが, 遠隔期に偽腔が拡大して破 裂した。緊急で胸部偽腔にCandy plug留置ならびに片側外腸骨 動脈リエントリー閉鎖を行った。もう1例は両側とも閉鎖を行わ なかった症例であり，経過観察中である。

【結語】慢性晚期例に対して, TEVARと現適応によるリエント リー閉鎖により胸部偽腔のリモデリング効果は上昇したが，偽 腔拡大を完全予防することはできなかった。今後, 両側腸骨動 脈リエントリー閉鎖を含んだ積極的リエントリー閉鎖による効 果を検討する必要がある。

Key words : Type B dissection, re-entry closure

\section{0-16-2 B型急性大動脈解離例において、発症後 2 週間後 の血管径の拡大は将来の大動脈関連有害事象を予測するか?}

神戸市立医療センター中央市民病院 循環器内科

$\bigcirc$ 三好悠太郎, 加地修一郎, 朴 美仙, 岡田大司,

佐々木康博, 豊田俊涁, 金 基泰, 北井 豪, 江原夏彦, 小堀敦志, 木下 㥀, 古川 裕

【背景】近年, Stanford B型急性大動脈解離（B型解離）例では, 胸部ステントグラフト内挿術 (TEVAR) による先制的治療が慢 性期の予後を改善すると報告されている。従ってB型解離例で は将来の大動脈関連有害事象を正確に予測することが急務であ るが，急性期の形態変化と予後の関係は未だ不明である。

【目的】本研究の目的は, 発症 2 週間後の血管径の拡大が将来の 大動脈関連有害事象を予測しうるかどうか検討することにある。 【方法】2009年から2019年の間に当院に入院した194人のB型解 離患者を後ろ向きに解析した。入院時と2週間後にCTで大動脈 長径を測定し， 2 週間で $2 \mathrm{~mm}$ 以上 $5 \mathrm{~mm}$ 未満の拡大を認める患者 群を中等度拡大群と定義した。7例では $5 \mathrm{~mm}$ 以上の拡大を認め たが, 全例で準緊急手術, TEVARの対象となったため除外した。 大動脈関連有害事象は, 破裂, 人工血管置換術, TEVAR, 大 動脈径拡大（血管径 $55 \mathrm{~mm}$ 以上または半年間で $5 \mathrm{~mm}$ 以上の拡大） と定義した。

【結果】患者の平均年齢は69歳で, 133 人（69\%）が男性であった。 中等度拡大は 35 人 (18\%) で認められ，そのうち 24 人 (69\%) に 大動脈関連有害事象を合併した。中等度拡大群ではその他の患 者群よりも大動脈関連有害事象を合併する率が有意に高かった (ハザード比 $4.59, \mathrm{p}<0.001$ )。多変量解析では, 入院時の大動脈長 径 $\geqq 40 \mathrm{~mm}$ （ハザード比 $3.26, \mathrm{p}<0.001 ）$ と中等度拡大（ハザー ド比 $4.53, \mathrm{p}<0.0001)$ が大動脈関連有害事象の強力な予測因子で あった。

【結論】 B 型解離例において, 発症 2 週間後の大動脈径拡大は大 動脈関連有害事象の強力な予測因子だった。急性期に大動脈径 の拡大を認める例では, 拡大が中等度であっても, 早期の治療 介入が必要である可能性が示唆された。

Key words : aortic dissection, TEVAR 


\section{0-16-3 保存的治療を行つたStanford B型急性大動脈 解離の中・長期予後}

鹿児島生協病院 循環器内科

○馬渡耕史, 常森将史, 春田弘昭

【目的】Stanford B 型大動脈解離（B型解離）の中・長期予後を 明らかにすること。

【対象・方法】2003年1月より2013年12月までに経験した急性大 動脈解離148例の内,腹部限局解離と $\mathrm{B}$ 型解離の急性期死亡5例を 除く B 型解離36例を対象に, 患者背景, 解離形態, 臨床経過と予 後の関連を検討した。（観察期間2019年まで,7〜 15年）

【結果】（1）性別；男性23例（64\%）女性13例（37\%）年齢；平 均70歳（40～87歳）で70歳以上が 17 例 $47 \%$ であった。(2) 発症 時の病型はDeBakey3a型5例,3b 型31例で3b 型が多かった。偽腔 の状態では偽腔開存型14例 (39\%) 血栓閉塞型22例（61\%，内 ULP型7例）で血栓閉塞型が多かった。（3）偽腔の経過を追え た 20 例のうち偽腔の縮小・消失 3 例, 血管径の $10 \mathrm{~mm}$ 以上の拡大 4 例,13例は変化がなかった。（4）経過中の死亡は10例（28\%）で 内7例の死因は感染症, 悪性腫瘍, 脳出血であった。解離関連の破 裂死は3例で2例が偽腔開存型, 1 例がULP型の血栓閉塞解離で, 切 迫破裂の 1 例は救命できた。4例とも血管径は $10 \mathrm{~mm}$ 以上拡大し ており,1例は血栓閉塞型が開存型になり偽腔が拡大し,その後 $\mathrm{A}$ 型解離を発症した破裂例であった。（5）非破裂例での血管径の 変化とULPの有無との関連は認めなかった。

【総括】B型解離の中・長期予後の破裂は血管径の拡大と関連が あり,定期的な経過観察と積極的な外科的介入が求められる。

Key words : acute aortic dissection, prognosis

\section{0-16-4 B型double barrel大動脈解離に対する PETTICOATカンジキ法と留意点}

1 愛知医科大学 血管外科, ${ }^{2}$ 愛知医科大学 放射線科 ○石橋宏之 ${ }^{1}$, 山田哲也 ${ }^{1}$, 折本有貴 ${ }^{1}$, 丸山優貴 ${ }^{1}$, 今枝佑輔 ${ }^{1}$, 三岡裕貴 ${ }^{1}$, 有馬隆紘 ${ }^{1}$, 鈴木耕次郎 $^{2}$, 萩原真清 ${ }^{2}$, 池田秀次 ${ }^{2}$

[諸言] 偽腔開存型 B 型大動脈解離に対するステントグラフト (SG) 手術におけるSG末端新規裂口（d-SINE）防止目的で, PETTICOATカンジキ法を多様している。[対象と方法] 本法 は, PETTICOAT法の末梢ベアステント内に2つ目のSGを留置 する方法であるが, ベアステントが雪道用カンジキの働きをし てSG下端でのd-SINE形成を防止できる。2017/10から偽腔開存 型 B 型解離を主として21例にPETTICOATカンジキ法を施行し た。急性5例, 亜急性6例, 慢性10例で, 使用 SG は CTAG 6例, TXD 15例であった。中枢留置部位はzone-1 1, z-2 11, z-3 4, z-4 5例であり，分枝チムニーステント 2 例, LSAバイパス 1 例を 併施した。ベアステント留置は胸部のみ, 2本目 SGはベアステ ント下端の $1 / 2$ ステント上までを原則としたが，2例でベアステ ントを腹部大動脈まで延長した。SG留置長165-297mm（中央值 $231 \mathrm{~mm}$ ), ベアステント留置長5-138mm（中央值23 mm）であっ た。SG中枢径に対する末梢径の差は, +3mm 1例, $0 \mathrm{~mm} 6$ 例, $-4 \mathrm{~mm}$ 8例, - $10 \mathrm{~mm}$ 6例であった。全例生存退院し, d-SINE, 対 麻痺などを認めなかったが, SG中枢端による弓部内膜損傷で
広範脳梗塞 1 例を認めた。リモデリング率（真腔面積/全大動 脈面積）は, 術後 1 ケ月で遠位弓部 $64 \pm 26 \%$, 大動脈弁レベル $62 \pm 27 \%$ ，ベアステント下端部 $51 \pm 23 \% ， 6$ ケ月でそれぞれ 87 $\pm 22 \%, 83 \pm 22 \%, 61 \pm 31 \%$ あった。[結語] B型大動脈解離 に対するPETTICOATカンジキ法は, d-SINE形成を防止でき, 良好な中期リモデリングが得られた。

Key words : aortic dissection, d-SINE

\section{0-17-1 大動眽解離破裂に対してopen stent graftを用 いた弓部大動脈置換術}

安城更生病院 心臓血管外科

$\bigcirc$ 阪本瞬介, 梶山 洸, 寺西智史, 金光真治, 水元 亨 open stent graft（OSG）法は製品化され大動脈弓部手術に使用 されている。今回大動脈解離破裂に対し OSG 法を用いた弓部置 換術で救命できた3例を経験したので報告する。

症例 1 は72歳男性, 16 年前に A 型急性大動脈解離（AAD）で上 行置換術施行。(2020年) 胸痛で発症しショック状態で搬送。 $\mathrm{CT}$ で慢性解離性胸部大動脈瘤（TAA）破裂，左胸腔穿破と診 断し, 準緊急で弓部全置換術を施行した。OSG ランディング 部位に偽腔はなく大動脈径は $31 \mathrm{~mm}$ で, 径 $35 \mathrm{~mm} /$ ステント長 $120 \mathrm{~mm} の$ J-graft open stent graft（JOSG）を $14 \mathrm{~cm}$ 挿入した。 症例 2 は 67 歳男性, 来院時ショック, 救急外来で挿管, CTで B 型 $\mathrm{AAD}$ 破裂, 左胸腔穿破と診断し, 緊急で弓部全置換術を施行 した。OSGランディング部位の大動脈径 $38 \mathrm{~mm}$ で, 径 $29 \mathrm{~mm} /$ ス テント長 $90 \mathrm{~mm} の J O S G を 10 \mathrm{~cm}$ 挿入した。

症例3は77歳男性, 前日発症の背部痛で紹介。CTで縦隔と左胸 腔に血腫を伴う B 型 AAD と診断したが，血行動態は安定したた め, 待機的に手術施行した。手術はJOSG（径 $27 \mathrm{~mm} /$ ステント 長 $90 \mathrm{~mm}$ ，ランディング部位の大動脈径は $33 \mathrm{~mm}$ ）を左鎖骨下動 脈中枢側の弓部から下行大動脈に挿入し，左鎖骨下動脈を再建 した。

3例とも術後に再破裂なく, 手術直後の CT T゙エンドリークを認 めなかった。対麻痺や脳梗塞も認めなかった。遠隔 CT フォロー

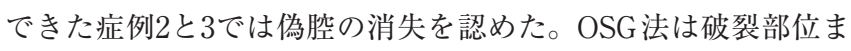
で大動脈を剥離/置換することなく止血が期待でき，血行動態 が不安定な大動脈破裂症例に対しても低侵襲化が可能な術式で ある。AADでは OSG ランディング予定部の大動脈径の $80 \%$ を 基準にJOSG 径を決定したが, 症例を重ねより適切なサイジング を検討していく。

Key words : open stent grafting, thoracic aortic rupture

\section{0-17-2 DeBakeylllb型逆行性大動脈解離 (RTAD) に 対する胸部ステントグラフト術 (TEVAR) の早期および遠 隔成績}

${ }^{1}$ 一般財団法人脳神経疾患研究所総合南東北病院 心臟血管 外科, ${ }^{2}$ 須賀川病院 心臟血管外科

$\bigcirc$ 新妻 健 ${ }^{1}$, 緑川博文 ${ }^{1}$, 植野恭平 ${ }^{1}$, 滝浪 学 $^{1}$, 影山理恵 ${ }^{1}$, 菅野 惠 $^{1}$, 佐藤晃一 ${ }^{2}$, 高野隆志 ${ }^{2}$

【背景】当院におけるRTADに対するTEVAR治療成績を後方 視的に検討した。 
【対象及び方法】2011年1月から2020年4月までRTADに対する 手術施行は32例であり, 内 TEVAR 7例（21.8\%，年齢37-72歳, 平均63歳, 男女比4:3）を対象とした。全例血管造影装置の完備 した手術室にて手術施行した。適応基準は，TEVARにて entry 閉鎖しえること，ないし外科手術がハイリスクと考えられる症 例に適応した。末梢留置部位との口径差がある場合は，複数個 留置とし, 腹部藏器還流障害などの場合はTX-Dによる真腔拡 大を試みることとした。

【結果】5例（71\%）は発症後24時間以内に，その他は 15 日，30 日後に各 1 例施行した。使用機種は全例 TAG/C-TAGであり, TX-Dを 1 例に追加した。Zone 2 landingを4例（57\%）に行い， 全例留置に成功, 外腸骨動脈解離, 晚期心タンポナーデを各1 例認めたが，他合併症なく，全例退院となった。近接期大動脈 関連イベントは, 術後19日に proximal stent-graft induced new entry（PSINE），術後40日に上行大動脈偽腔開存により Frozen elephant trunk併用全弓部置換を2例に施行，術成功し，全例遠 隔期まで問題なく生存している。

【結語】RTADに対するTEVARの成績は，限定的な症例ではあ るが，低侵襲に速やかに治療しえる手法であることは間違いない。 しかし，その適応やSINEの問題など未だ解明していない問題が あり，今後も検討を重ねていく必要があると考えられた。

Key words : RTAD, TEVAR

\section{0-17-3 慢性大動脈解離に対するFET法後のDistal SINEによる破裂に対してTEVARを施行した 1 例}

久留米大学 外科学講座

新谷悠介, 大塚裕之, 姉川朋行, 押領司篤宣, 朔 浩介, 菊先 聖, 財満康之, 古野哲慎, 中村英司, 庄嶋賢弘,

高木数実, 高瀬谷徹, 廣松伸一, 田山栄基

【背景】近年大動脈解離症例に対するOpenstent graft（OSG） を用いたFrozen Elephant trunk（FET）法は有用な手術手段 として報告されているが, 慢性大動脈解離症例に対する有用 性に関しては未だに意見が分かれる。今回，慢性大動脈解離 症例に対するFET法後の Distal Stentgraft induced new entry (dSINE) による破裂に対して，緊急TEVARで救命できた1例 を経験したので報告する。

【症例】73歳男性。B型大動脈解離発症後9か月後に大動脈径の 急速拡大を認め, FET 法による全弓部大動脈人工血管置換術 $(\mathrm{OSG} 27 \times 120 \mathrm{~mm}$, 日本ライフライン $)$ を施行した。術後 1 年目の 造影 CTで OSGの小弯側末梢にdSINEを認めたが，前医にて外 来経過されていた。手術から 1.5 年後に突然の胸背部痛が出現し 近医搬送となり，造影 CTにて dSINEからの大動脈破裂が疑わ れ直ちに当院転院となった。搬入時はショックバイタルであり， 緊急でTEVAR（Zenith Alpha）を施行した。留置後血圧は安 定し，術後経過も良好。術後18日目に自宅退院となった。

【まとめ】dSINEの発症率はTEVAR と OSG 併せて, 3.4-35\%と 報告により様々である。慢性大動脈解離症例に対するFET法 によるTAR手術は，OSG 留置後の Springback forceや radial forceによるdSINEの発生が問題である。また，OSGの末梢留置 位置やデバイス選択に関しても未だ議論の余地がある。本症例
より慢性大動脈解離症例に対する FET 法の問題点や今後の課題 を文献的考察を含めて報告する。

Key words : d-SINE, Openstent graft

\section{0-17-4 右下肢虚血を合併したB型急性大動脈解離に対} して、緊急debranching TEVARを施行した 1 例

${ }^{1}$ 奈良県立医科大学 胸部 - 心臓血管外科, ${ }^{2}$ 奈良県立医科 大学 放射線科

○殿村 玲 $^{1}$, 廣瀬友亮 ${ }^{1}$, 阿部毅寿 ${ }^{1}$, 早田義宏 ${ }^{1}$, 平賀 俊 $^{1}$, 福場遼平 ${ }^{1}$, 武村潤一 ${ }^{1}$, 三谷和大 ${ }^{1}$, 市橋成夫 ${ }^{2}$, 岩越真一 ${ }^{2}$, 田口秀彦 ${ }^{2}$, 永富 暁 $^{2}$, 中井貴大 ${ }^{2}$, 吉川公彦 ${ }^{2}$, 横山晋也 ${ }^{1}$, 谷口繁樹 ${ }^{1}$

【症例】56歳, 男性。高血圧にて近医加療中。突然の心窩部痛 と移動する背部痛を主訴に前医受診。造影 CT 検査にて, 弓部 大動脈鎖骨下動脈分岐部から両側総腸骨動脈にかけて偽腔開 存型の大動脈解離を認め, 右総腸骨動脈でflapを伴う dynamic obstructionを認めた。加療目的に当科搬送となった。搬送時右 下肢冷感あり，足背動脈も触知できなかったが，ICU入室後ま もなくして足背動脈触知可能となり, 冷感も消失した。保存的 加療としたが, 翌日に再度右下肢痛が出現。造影 CT 検查で右総 腸骨動脈以遠に造影不良を伴う解離像を認めたため, 緊急手術 の方針とした。

【手術・経過】右腸骨動脈領域へのステント留置と大腿動脈人工 血管置換術を想定し, 手術を開始したが, 右大腿動脈を切開す ると解離を認めなかった。血管造影にて terminal aortaでの血流 途絶を確認した。腸骨動脈にステントを留置した場合, re-entry のみを閉鎖してしまうため危険と判断し, TEVARで entry 閉鎖 を行う方針とした。ZONE 2 にGORE cTAGを留置した。下肢 の血流改善を確認したため, 腸骨動脈領域へのステント留置は 不要と判断した。左上肢の血圧低下を認めたため, $8 \mathrm{~mm}$ GORE PROPATENで左総頚動脈-左鎖骨下動脈バイパス術を行った。 術後経過良好であり，POD 3に一般病棟転棟，POD 29に独歩自 宅退院となった。

【結語】右下肢虚血を伴うB型急性大動脈解離に対し, 緊急 TEVARを施行し良好な結果を得た。

Key words : acute aortic dissection, TEVAR

\section{0-17-5 術前解離による右内頚動脈閉塞, 広範囲脳梗塞 を合併した急性大動眽解離に対して急性期に手術を行い良 好な結果を得た一治験例}

奈良県立医科大学附属病院 胸部・ 心臟血管外科

○平賀 俊, 廣瀬友亮, 阿部毅寿, 早田義宏, 福場遼平, 武村潤一，殿村 玲，三谷和大，横山晋也，谷口繁樹 急性大動脈解離に対する手術成績は向上しているが, 術前に解 離による臓器血流障害を合併している症例の成績は依然不良で ある。中でも術前に広範囲脳梗塞を合併している症例について は, 術中人工心肺使用に伴う抗凝固療法による脳出血のリスクも 高く手術適応については確立されていない。我々は術前に広範 囲脳梗塞を合併した急性大動脈解離に対して急性期に手術を行 い, 術後頭蓋内病変の増悪を認めず比較的良好な結果を得た一例 
を経験したので報告する。症例は77歳, 男性。既往歴は2年前に 左眼網膜剥離に対して手術既往あり。2月6日に自宅内で転倒し， 以後歩行困難が出現した。2月7日に近医を受診し, 左不全片麻痺 を認められた。頭部MRIを施行され, 右内澒動脈の閉塞, 右大脳 半球に急性期梗塞を認められた。胸腹部 CTで, Stanford A型の 大動脈解離, 解離による右内頝動脈閉塞を認められ当院に紹介さ れた。心エコー検査では心襄液貯留, 大動脈弁閉鎖不全は認めな かった。頭部 CTを施行し脳出血のないことを確認した後, 緊急 手術を施行した。手術は右頚部を切開し右内澒動脈を結紮閉鎖 した後, $24 \mathrm{~mm}$ Triplex を用いて上行大動脈人工血管置換術, 同 人工血管から右腋窩動脈にバイパスを施行した。術後覚醒も問 題なく, 術前からの神経学的所見の悪化も認めず, 画像検査上脳 出血も認めなかった。術後第6病日に抜管, 第31病日にリハビリ テーション目的に転院した。

Key words : Acute aortic dissection, Cerebral infarction

\section{0-18-1 A型急性大動脈解離術後,再開心術症例の検討}

${ }^{1}$ 高の原中央病院, ${ }^{2}$ 済生会泉尾病院, ${ }^{3}$ 近大奈良病院 $\bigcirc$ 長阪重雄 ${ }^{1}$, 金田幸三 ${ }^{1}$, 西川浩史 ${ }^{1}$, 西脇 登 $^{2,3}$ 【目的】A型急性解離（DAA）術後の再開心術例につき検討し た。

【対象】DAA術後再開心術を要した15例（M/F10/5 緊急3例）, 年齢 $(62.8 \pm 10.4)$ 。

【疾患, 手術】手術適応の原因は大動脈関連病変 (Aortic indication A 群) : 上行大動脈吻合部狭窄 1 例, 人工血管感染 1 例,弓部拡大 6 例。非大動脈関連病変 (Non-aortic indication $\mathrm{N}$ 群) :AR4例 (PVE1例),MR1例,Angina + AR1例。重複:弓部 拡大 $+\mathrm{AR} 1$ 例,基部再解離 $+\mathrm{AR} 1$ 例。AR6例で初回手術時に手 術適応となるARは認めず。MVRを行った1例は初回手術時に sever MRを認めていた。手術は弓部拡大と人工血管感染の8例 に弓部置換,吻合部狭窄例に再上行置換 1 例, 基部再解離例に基部 形成1例を要した。Non-aortic indicationに対しAVR5例,Bentall 手術1例（PVE）,CABG4例,MVR1例を要した。胸骨正中切開 12 例,ALPUS incision3例で手術を行った。初回手術術式は弓 部拡大の7例,吻合部狭窄の1例,AR3例（PVE1例）で上行置換, 他の4例で上行弓部置換を施行されていた。合併手術はAVR4 例, CABG2例。再手術時人工心肺の送血部位は右腋窩 9 例,左腋窝 1例, 両側腋窝5例で全例 FA 送血を併用した。弓部置換の8例, N 群の3例で脳分離体外循環を要した。脱血部位はRA5例,SVC + IVC4例,SVC + FV2例,FV + PA3例,rt jugular V + FV1例。

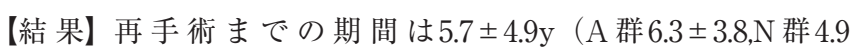
\pm 3.3 ）,ECC 時 間 $365.1 \pm 138.1 \mathrm{~min}$ 。AXA 時 間 $187 \pm 70.7 \mathrm{~min}$ 。 Bentall 手術施行例と人工血管感染例, 基部再解離で基部形成 + AVRを行った緊急例3例（20\%）をそれぞれLOS, 敗血症,基部 再出血で失った。

【結語】DAA術後15例に対し再開心術を行った。上行置換後の 弓部拡大 $47 \% \%, A R 40 \%$ を認め手術適応となった。手術症例は複 雑で術式や体外循環確立に送脱血部位の工夫を要した。

Key words : Acute Aortic Disection, Reoperation

\section{0-18-2 TAVI (Sapien3) 後に発症した急性大動脈解離 に対する治療経験}

聖マリアンナ医科大学 心臓血管外科

$\bigcirc$ 千葉 清, 北 翔太, 鈴木寛俊, 桜井祐加, 駒ヶ嶺正英, 向後美沙, 永田徳一郎, 縄田 寛, 近田正英, 西巻 博, 宮入 剛

緊急TAVI後に発症した急性大動脈解離の一治験例を報告する。 症例は60歳女性。Turner症候群にて身長 $141 \mathrm{~cm}$ と低身長で体重 $53.9 \mathrm{~kg}$ 。来院時の時点で著明な低酸素血症と循環不全のため, 気管抻管, 大動脈バルーンパンピングを留置後, 初期治療を開 始。経胸壁心エコーで2尖弁を伴う重度の大動脈弁狭窄症（peak velocity $5.0 \mathrm{~m} / \mathrm{s}$ ), 左室収縮能は $20 \%$ と低下していた。2尖弁と 年齢を考慮してSAVRを第一選択としたが，術前検査より算出 されたSTSリスクスコアは $16.5 \%$ とハイリスクのため, TAVR の方針とした。全身麻酔下, 経食道心エコーガイド下でSapien $323 \mathrm{~mm}$ を nominal で留置した。術後循環不全から離脱し, 術後 3日目に抜管。しかし術後に施行したCTで偽腔開存型Stanford $\mathrm{A}$ の大動脈解離を認めた。潅流障害はなく, 弁周囲の逆流を認 めなかったが術前と比較して大動脈基部から上行大動脈が $46 \mathrm{~m}$ $\mathrm{m}$ （術前 $42 \mathrm{~mm}$ ） と急速拡大していた。同一入院での手術の方 針とした。手術：大腿動脈送血，右房，下大静脈 2 本脱血にて人 工心肺を確立。循環停止後, 基部を観察すると, 右冠動脈起始 部近傍のバルサルバ洞の内膜をデバイスエッジが穿通し，そこ から entryを形成していた。腕頭動脈分岐部より中枢で末梢側 吻合を行い，側枝送血を行い循環再開。CEPマグナ $23 \mathrm{~mm}$ とバ ルサルバグラフト $26 \mathrm{~mm}$ のComposite graftを作成し, 基部置換 とした。右冠動脈は carrel patchでの再建は不可能であったた め大伏在静脈を用いて\#3にバイパスを行い, 手術を終了とした。 今回の治療戦略を振り返り, 文献的考察も踏まえて報告する。 Key words : TAVI, Turner Syndrome

\section{0-18-3 全周性の内膜断裂によるStanford A 型急性大 動脈解離の 1 手術例}

群馬県立心臟血管センター 心臓血管外科

○森下寛之, 江連雅彦, 長谷川豊, 山田靖之, 星野丈二, 岡田修一, 金澤祐太, 加我 徹

【背景】急性大動脈解離において全周性に内膜が断裂することは 稀である。全周解離した可動性の高い内膜 flap が血管内で重積 (intimal intussusception) し, 様々な合併症を引き起こすこと がある。intimal intussusceptionによる大動脈弁閉鎖不全症を発 症し, ショック状態で手術を施行した症例を経験したので報告 する。

【症例】77歳女性。骨粗鬆症, 腰椎圧迫骨折に対して抗スクレ ロスチンモノクローナル抗体製剤による治療の既往がある。来 院12時間前に胸痛を自覚し, 徐々に体動困難, 呼吸困難となっ たため当院へ救急搬送された。来院時血圧 60 台で意識レベル は低下。心エコー検査では大動脈基部にflapを認め，拡張期に 大動脈弁に嵌入していた。造影 CT 検査では弓部大動脈までの Stanford A 型急性大動脈解離と診断した。CT 上, 上行大動脈中 央部にはflap 認めなかった。血圧低值は改善せず，早急に手 
術の方針とした。人工心肺を確立し, 低体温循環停止として上 行大動脈を切開し内腔を確認すると, 腕頭動脈分岐部の中枢側 で全周性に内膜が断裂していた。解離した内膜がそれぞれ末梢, 中枢に翻転していた。大動脈弁に形態的な異常は認めず，断端 形成した上で，上行大動脈人工血管置換術を行った。

【考察】全周性に解離したflapがintussusception し，末梢側では 脳血流低下や急性循環不全, 中枢側では大動脈弁逆流や冠血流 低下を引き起こす。診断には，エコーが有用であるとされている。 様々な合併症により予後は不良との報告もあり, 本症例は迅速 な対応で救命し得た。また, 投薬されていた抗スクレロスチン モノクローナル抗体製椷は動脈にも影響を及ぼす可能性があり， 大動脈壁の脆弱化も思案された。

Key words : acute aortic dissection, intimal intussusception

\section{0-18-4 Frozen elephant trunkのSpring backに対 するTEVARについての検討}

${ }^{1}$ 済生会横浜市東部病院 心藏血管外科, ${ }^{2}$ 荻窪病院 心臓 血管外科, ${ }^{3}$ 慶應義塾大学 外科学 (心蔵血管)

$\bigcirc$ 飯田泰功 ${ }^{1}$, 岡 英俊 ${ }^{1}$, 稲葉 佑 $^{1}$, 三木隆久 ${ }^{1}$, 松岡志超 ${ }^{2}$, 浅野竜太 ${ }^{2}$, 藤井 奨 $^{2}$, 澤 重治 $^{2}$, 志水秀行 ${ }^{3}$ はじめに: Stent graft-induced new entry（SINE）は, 未治 療の場合, 致死的になることもあるため, 可及的早期の対応 が望ましいと考える。我々は, 急性 A 型解離に対する Frozen elephant trunk（FET）法術後に生じたSpring backに対し, 積 極的にpreemptive TEVARを行ってきたので，その術式と治療 成績について報告する。対象と方法：2017年1月から 2020年4月 までに急性 A 型解離に対して全弓部置換術（TAR）＋FETを施 行した70例のうち, 画像診断でSpring backを認め, TEVARを 施行した3例を対象とした。男性1名, 女性2名で平均年齢は51土 7 （45-58）歳であった。結果：初回術後から追加TEVARまで平 均573土218日で, 全例において中枢側 landing FET 内に取り, 末梢側は下行大動脈を全長にわたりカバーする方針とした。技

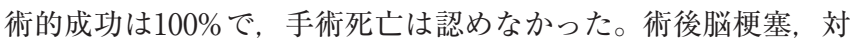
麻痺などの合併症も認めなかった。ステント遠位端はTh11が1例, Th12が2例であった。術後造影 CT ではステント留置部位およ び横隔膜下の first tear までの偽腔血栓化を確認できた。考察 : 前回手術時の FET の長さが $60 \mathrm{~mm}$ のものを2例に認め, 大動脈 離断部位が左総澒動脈一左鎖骨下動脈間ということを考えると FETが短く, Spring backを惹起しやすいと考えられた。症例 数が少ないが, 対麻痺の発症を認めなかった。結語 : 急性 $\mathrm{A}$ 型 解離に対する TAR + FET術後のSpring backに対するTEVAR は症例は少ないが良好な成績であった。Spring backの状態の時 にPreemptive TEVARを行うことで, dSINEの発生率低下につ ながると考えられた。さらなる症例数と検討を要する。

Key words : frozen elephant trunk, spring back

\section{0-18-5 大動眽解離に対するオープンステント法術後の SINE}

${ }^{1}$ 兵庫県立姫路循環器病センター 心臓血管外科, ${ }^{2}$ 兵庫県 立姫路循環器病センター 放射線科

$\bigcirc$ 野村佳克 ${ }^{1}$, 孟 順 $^{1}$, 塩川桂一 ${ }^{1}$, 河嶋基晴 ${ }^{1}$,

藤末 淳 $^{1}$, 藤本将人 ${ }^{1}$, 宮原俊介 ${ }^{1}$, 深瀬圭吾 ${ }^{1}$, 松代啓吾 ${ }^{2}$, 丸山晃司 ${ }^{2}$, 小出 裕 $^{2}$, 田中裕史 ${ }^{1}$, 本多 祐 $^{1}$, 川崎竜太 ${ }^{2}$, 村上博久 ${ }^{1}$

【背景と目的】 Frozenixは本邦で開発された市販のオープンス テントグラフト (OSG) である。大動脈解離に対して, 弓部全 置換術 (TAR) +OSGを施行し術後経過観察中にStent graft induced new-entry（SINE）が発生することがある。発生頻度や 追加治療について報告する。

【方法】2014年から2020年3月までに当院でTAR+OSGを留置し た症例は99例であった。大動脈解離に対して手術し, 術後6ヶ 月以上経過観察可能であった70例を対象とした。A型解離 59 例 $(84.3 \%$ ），B型解離 11例（15.7\%）であった。急性期 44例 (62.9\%), 亜急性期・慢性期 26 例 $(37.1 \%)$ であった。術後平均 観察期間は24.7 13.6 ケ月であった。

【結 果】術後 paraplegia 5 例 (7.1\%) で認めた。大動脈 Remodeling は胸部 35 例 (50\%) で得られた。SINEは9例 (12.9\%) で発生し, 術後平均 $17.7 \pm 11.7$ ケ月で発症した。急性期 4例 (9.1\%), 慢性期5例（19.2\%）であった（ $\mathrm{p}=0.2 ）$ 。急性期で は大動脈径に対する Oversizing rateはSINE 78.7 $2.5 \%$, Non SINE $74.8 \pm 9.8 \%$ であった（ $\mathrm{p}=0.5 ）$ 。慢性期では真腔径に対する Oversizing rate は SINE 105.3 $\pm 13.1 \%$, Non SINE 106.3 $\pm 9.2 \%$ であった $(p=0.1)$ 。吻合部から OSG 末梢までの角度の変化や, OSGの長さに関しても両群で有意差は認めなかった。SINE症例 に対する再治療は全例TEVARを施行した。TEVAR後は全例 でSINE部分の血流は消失し新規 SINEは認めず。術後, 脊髄虚 血は認めず。

【結語】TAR+OSG 後のSINEを9例（12.9\%）で認めた。慢性解 離に多い傾向にあったが, 有意差は認めなかった。oversizing rate や術後の OSG 末梢の角度の変化についても有意差は認めな かった。追加治療では合併症なく経過し, 良好な経過を得ている。 Key words : SINE, TEVAR

\section{0-19-1 演題取下げ}

\section{0-19-2 Radial 2ring slim fiberを用いた側枝静脈瘤の レーザー焼灼術}

1 熊本血管外科クリニック， ${ }^{2}$ 菊池中央病院

$\bigcirc$ 宇藤純一 ${ }^{1}$, 塚本芳春 ${ }^{2}$, 信岡博済 ${ }^{2}$

【はじめに】血管内レーザー焼灼術（以下EVLA）では，不全伏 在静脈を焼灼した後に, 側枝静脈瘤をstab avulsionすることが 一般的である。我々は最近, 静脈瘤を直接穿刺し細径ファイバー を瘤内に挿入し焼灼する方法を試みている。その手技と成績に ついて報告する。

【対象と方法】2019年12月以降に行ったGSV 弁不全に対する EVLA 110肢を対象とした。波長 $1470 \mathrm{~nm}$ の Biolitec社製 ELVeS 
レーザー装置にRadial 2ring fiberを接続してEVLAを行った。 使用したファイバーは細径タイプ（直径 $1.27 \mathrm{~mm}$ ：以下 Slim) もしくは標準サイズ（直径1.85 mm：以下Regular）の2種。Slim の挿入には16G 静脈留置針を用い, Regularの挿入には6Frのシー スイントロデユーサーを使用した。麻酔はTLA と静脈麻酔を併 用し, GSVの焼灼はSlimでは出力7W, Regularでは7 9Wで行い, 静脈瘤は $5 \mathrm{~W} て ゙$ 焼灼した。術後1か月目に焼灼した瘤の退縮状況 を6段階（0:遺残瘤なし〜 $5: 75 \%$ 以上遺残）で評価した。

【結果】Slim を用いた症例は44肢で, GSV 焼灼長は平均 $36.0 \mathrm{~cm}$, 瘤焼灼は平均 5.7 回, 手術時間の平均は 29.7 分であった。術後に 神経障害, 血栓性静脈炎, 皮膚熱傷などの有害事象はみられな かった。Regularを用いた66肢では, GSV 焼灼長は平均 $38.8 \mathrm{~cm}$, Stab avulsionを39肢に併施し，手術時間は平均25.8分であった。 術後 1 ケ月目，すべてのGSVで閉塞が確認された。Slim群での 瘤退縮所見は，遺残瘤10\%未満（0-1）が41肢（93\%)，10-50\% 遺残（2-3）が2肢（5\%)，50\%以上遺残（4-5）が1肢（2\%）と いう結果であった。

【結語】細径ファイバーによる静脈瘤焼灼術は有害事象が少なく 整容性に優れ，症例を選んで適応すればStab avulsion法の代替 手技として有益と思われた。

Key words : varicose vein, ebdovenous laser ablation

\section{0-19-3 下肢静脈瘤高周波焼灼術の早期治療成績 一血 管内レーザー治療との比較検討一}

${ }^{1}$ 川崎医科大学 心臓血管外科, ${ }^{2}$ 川崎医科大学 生理学 1 $\bigcirc$ 田淵 篤 ${ }^{1}$, 柚木靖弘 ${ }^{1}$, 渡部芳子 ${ }^{2}$, 桑田憲明 ${ }^{1}$, 田村太志 ${ }^{1}$, 古澤航平 ${ }^{1}$, 山澤隆彦 ${ }^{1}$, 金岡祐司 ${ }^{1}$, 種本和雄 【目的】高周波焼灼術（RFA）の早期治療成績, 自他覚症状求よ び静脈機能の改善を血管内レーザー治療（EVLA）と比較検討 する。

【対象，方法】RFA 142肢（2018年11月－2019年12月）および EVLA 1256肢（2011年10月－2019年12月）を対象とした。RFA はSFJの20mm 末梢から ClosureRFGTM（Covidien）を用いて 平均治療長 $29.5 \mathrm{~cm}$ 焼灼し, 下腿部静脈瘤は EVLA 症例と同様 に $0.5 \%$ ポリドカノールによる下腿部本幹フォーム硬化療法を 行った。術翌日，7-10日，1，6，12力月で経過観察し, 合併 症, Venous Clinical Severity Score（VCSS）を検討した。超 音波検査で治療血管閉塞，EHIT，DVTの有無を検討し，静脈 機能は空気容積脈波法でVenous Filling Index (VFI), Venous Volume（VV）を測定して術前後值を比較し，EVLAの結果と 比較検討した。

【結果】初回外来時の焼灼部疼痛はRFA 11.2\%, EVLA 55.7\%, 皮下出血はRFA 12.5\%，EVLA 26.0\%にみられ，RFAで有意に 低值であった。VCSSは術前 $5.2 \pm 2.8,1$ 力月 $2.3 \pm 1.2,6$ 力 $1.5 \pm$ 1.4，12力月 $1.1 \pm 1.0$ で術後有意に改善した。術後1カ月でEHIT class 32 例 $(1.4 \%)$, ヒラメ静脈血栓症 4 例, 術後6力月で再疎通 3例を認めたが, EVLA と有意差はなかった。VFI, VVの術前值 $5.9 \pm 3.7,154.0 \pm 61.6$, 術後 1 力月 $2.5 \pm 1.4,129.0 \pm 49.3,12$ 力月 1.9 $\pm 0.7,112.1 \pm 29.0$ で静脈機能は術後有意に改善し, EVLA と有 意差はなかった。RFA 治療期間中にEVLAを選択した症例は 10
例で, 再手術例, 短区域の病変, 穿刺部位の血管径が細い例で あった。

【結語】RFAの早期治療成績, 術後の自他覚症状や静脈機能 の改善はEVLA と同等であり, 術後の治療部痛, 皮下出血は EVLAより低頻度であった。

Key words : radiofrequency ablation, varicose vein

\section{0-19-4 下肢静脈瘤に対するEHIT関連因子}

北海道循環器病院

$\bigcirc$ 岩朝静子, 山崎健二, 広藤愛菜, 道井洋吏

【目的】下肢静脈瘤に対する治療は, 現在レーザー焼灼術が主流 となっている。しかし，ストリッピング手術では起き得なかっ たEndovenous Heat Idiopathic Thrombosis（EHIT）の危険性 が報告されている。実臨床から，そのリスクとなりうる因子を 精査する。

【方法】2018年1月から2020年3月までに下肢静脈瘤に対して大伏 在静脈レーザー焼灼術を行った患者172例を対象とした。下肢静 脈エコーは術後7日以内・1か月後・半年後に施行した。初回の エコーにて, EHIT1以上を認めたものをE群81例，ないものを C 群91例として比較検討した。

【結果】平均年齢は $\mathrm{E}$ 群 $67.0 \pm 12$ 歳, $\mathrm{C}$ 群 $68.5 \pm 10.4$ 歳, $\mathrm{E}$ 群女性 54 例 $(66.7 \%) ， \mathrm{C}$ 群女性62例 $(68.1 \%$ ）と，E群に男性が有意 に多かった。治療前の大伏在静脈径は $\mathrm{E}$ 群 $7.3 \pm 1.8 \mathrm{~mm}, \mathrm{C}$ 群 6.4 $\pm 1.4 \mathrm{~mm}$, 焼灼時の平均エネルギーは $\mathrm{E}$ 群2637.1J, C群2403.9J, 焼灼時間は $\mathrm{E}$ 群329.1秒, C 群301.8秒と, いずれも $\mathrm{E}$ 群が有意に 高かった。LEED はE 群 $68.6 \mathrm{~J} / \mathrm{cm}, \mathrm{C}$ 群 $65.2 \mathrm{~J} / \mathrm{cm}$ と, 有意差を 認めなかった。E群は術後1か月後のフォローにてEHIT22例へ 減少していた。半年後のフォローは E 群62/81例（76.5\%）にて 可能であり，1例のみEHIT1を認めた。全期間において，肺塞栓 を疑う様な呼吸苦・胸痛などの自覚症状は認めず, 経過観察の みで軽快した。

【結論】下肢静脈瘤に対するレーザー焼灼術における EHIT 発生 の傾向として, 男性・大伏在静脈径・治療エネルギー・時間が 関連していると思われた。EHITは注意を要する合併症であり， 性差によって，治療戦略を変更することが必要かもしれない。 Key words : varix, EHIT

\section{0-19-5 下肢静脈瘤に対するシアノアクリレート系接着材 による血管内治療の初期治療成績}

お茶の水血管外科クリニック

○広川雅之, 栗原伸久, 伴 祐子

【はじめに】現在，下肢静脈瘤に対する血管内焼灼術は，伏在 型静脈瘤の標準的外科治療となっている。しかし，欧米では非 焼灼非浸潤麻酔（non-thermal non-tumescent: NTNT）治療と 呼ばれる，より低侵襲な血管内治療が開発されている。今回わ れわれは，わが国で2019年に保険収載されたNTNT 治療である シアノアクリレート系接着材による血管内治療（cyanoacrylate closure: CAC）による初期治療成績を報告する。

【対象と方法】2019年12月より2020年3月までにCACを施行した 一次性下肢静脈瘤症例54例72肢（平均年齢65歳）を対象とした。 
手術はVenaSealクロージャーシステムを使用し, 局所麻酔でエ コーガイド下に伏在静脈を穿刺し, 接着材をプライミングした デリバリーカテーテルを深部静脈接合部の $5 \mathrm{c} \mathrm{m}$ 遠位部まで挿入, 接着材の注入と圧迫を繰り返して伏在静脈を閉鎖した。術後に 弾性ストッキングは着用させなかった。術後 1 週間，1ヶ月およ び3ヶ月後に経過観察と超音波検査を行った。

【結果】両側同時例が18例, 治療静脈はGSV, SSV, 副伏在静脈 がそれぞれ54，16，3本，平均手術時間は30分 (10-62分), 治療 静脈長は $28 \mathrm{~cm}(7-55 \mathrm{~cm})$, 使用接着材量は $1.1 \mathrm{cc}(0.4-2.4 \mathrm{cc})$ で あった。術後合併症は表在静脈血栓症が9例 (17\%), phlebitis が6例 (11\%), 全身性のIV型過敏症およびEHIT class2様の血 栓突出がそれぞれ1例ずつ認められた。全身性のIV 型過敏症は 抗ヒスタミン薬およびステロイド内服による治療を行った。平 均観察期間は38日（7-120日）で，再疎通を3例（術後7日，34日， 57日目）に認めた。

【まとめ】下肢静脈瘤に対するCACは重篤な合併症は認められず, 低侵襲で安全な治療であった。

Key words : VARICOSE VEINS, CYANOACRYLATE

\section{0-19-6 慢性静脈疾患患者の下肢細胞外液量の検討}

山口大学器官病態外科 血管外科

○廣晃太郎, 溝口高弘, 永瀬 隆, 竹内由利子,

佐村 誠, 原田剛佑, 森景則保, 濱野公一

【目的】静脈性浮腫は, 静脈高血圧の結果, 血管外に漏出する液 体の量がリンパドレナージを上回った状態と考えられる。多く の場合, 静脈高血圧の原因は静脈逆流とされるが, 肥満や加齢 等の患者因子が関与することも知られている。そこで今回我々 は, 患者因子や静脈機能検査から得られるパラメーターのうち, どの因子が慢性静脈疾患患者の下肢細胞外液量に影響を与えて いるかを検討した。

【方法】2016年9月から2019年3月の間に, 当院に下肢静脈瘤を訴 えて受診した患者 146 人のうち，下肢浮腫を来す基礎疾患のある 患者, 下肢機能障害のある患者を除く79名を検討した。初診時 に静脈エコー, 空気容積脈波検査 ( $\mathrm{APG})$, 生体インピーダンス 測定（BIA）を行った。APGから静脈機能の指標としてvenous filling index (VFI), ejection fraction $(\mathrm{EF})$, residual volume fraction（RVF）を算出した。また，下肢細胞外液量の指標とし て下肢細胞外液量 -上肢細胞外液量比（ReL/ReA）を算出した。 【結果】 ReL/ReAはCEAP クラスの上昇に伴い減少していた。 (C0,1: 0.79 [0.60-0.98], C2: 0.77 [0.56-1.08], C3: 0.67 [0.57-0.85], C4: 0.64 [0.44-0.89], $\mathrm{p}<0.001)$ 。多変量解析の結果, 細胞外液量

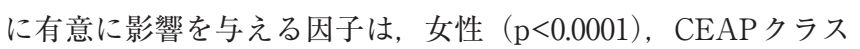
( $\mathrm{p}<0.0001)$ であり, ReL/ReA とVFI, EF, RVFとの間に有意 な相関はみられなかった。

【結語】慢性静脈疾患を伴う下肢の細胞外液量に有意な影響を与 えるのは患者因子や下肢の症状であり, 静脈機能の影響はより 小さい可能性が示唆された。

Key words : chronic venous disease, bioimpedance analysis

\section{0-20-1 当院における妊産婦の下肢深部静脈血栓症に対 する抗凝固療法の検討}

熊本赤十字病院 心臓血管外科

$\bigcirc$ 松川 舞, 和田健史, 宮本智也, 浦下周一, 上木原健太, 坂口 健, 平山 亮, 中島昌道, 鈴木龍介

【背景】肺動脈血栓塞栓症（PE）は妊産婦死亡の主要な原因の 一つであり, 致死的な PEを防ぐには, 深部静脈血栓症（DVT） の予防と早期診断・早期治療が重要である。

【目的】当院での妊産婦下肢DVT症例の治療と転帰を提示し, 抗凝固療法の適応について検討する。

【方法と結果】2010年1月から2019年12月まで, 当院で下肢 DVT 診断・治療を行った妊産婦15例を対象とした。発症時期は, 妊 娠初期 6 例，中期 2 例，後期 2 例，産裖期 5 例（産裖3,4,5,6,9日目） であった。血栓部位は, 総腸骨静脈 5 例, 外腸骨静脈 3 例, 大腿 静脈1例, 膝窝静脈3例, 下腿静脈3例であった。治療選択は, 圧 迫療法は8例で, 抗凝固療法は11例, IVCフィルター留置したの は6例（うち1例はDVT再発時に留置）であった。対象期間中の DVT 再発は4例で, 妊娠初期に膝窩静脈 DVT 発症して一旦血栓 消失したが分娩後に下大静脈レベルまで血栓認めるDVTを発症 かつPE併発した1例, 妊娠初期に総腸骨静脈 DVT発症して再妊 娠時に膝窩静脈 DVTを発症した1例, 同様に産裖期にヒラメ静 脈DVT発症して再妊娠時にヒラメ静脈DVTを発症した1例, 抗 リン脂質症候群で産裖期に総腸骨静脈 DVT発症し, ワルファ リン中断後一ヶ月で初発とは対側の滕窝静脈DVTを発症した1 例であった。いずれも抗凝固療法を行っていない状況で症候性 DVT再発を認めていた。

【結論】妊産婦の下肢DVT15例では, 4例で症候性DVTを再発 していた。DVT再発は, 抗凝固療法を行っていない状況下で, 抗リン脂質抗体症候群の患者を除き, 産裖期 - 再妊娠期間に起 きていた。妊産婦でDVT発症した症例では, 未梢型・中枢型問 わず, 妊娠期・産裖期間の抗凝固療法を検討すべきと考えられた。 Key words : deep vein thrombosis, pregnancy

\section{0-20-2 当院における左下肢急性腸骨大腿静脈血栓性閉 塞に対するカテーテル治療の検討}

総合高津中央病院 循環器内科

$\bigcirc 丸 山$ 高, 宮本 明

背景: 左総腸骨静脈 (CIV) は, 右総腸骨動脈と第 5 椎体で圧 迫されやすく, 深部静脈血栓症（DVT）の原因となる（MayTurner-Syndrome : MTS)。今回, 当院における左下肢急性腸骨 大腿静脈静脈血栓閉塞（AIFVO）に対するカテーテル治療につ いて検討した。対象および方法：2015年3月から2020年4月まで にAIFVOによる左下肢腫脹を生じた 12 例（男性 9 名, 平均年齢 $57.7 \pm 17.7$ 歳) に対してカテーテル治療を実施した。肺塞栓は 8 例に合併していた。全症例, 左膝窩静脈アプローチで血栓吸引 およびバルーン拡張術後にパルススプレーカテーテル留置によ る持続直接血栓溶解療法（CDT）を実施した。下大静脈（IVC） フィルターは術前に全例に留置した。CDT後に左CIVの高度狭 窄例ではステントを留置した。CTにてIVCおよび左CIV 径を測 定し, ステント留置の有無を比較した。結果：初期成功は全例 
で得られ, 左 CIVにステントを4名で留置した。IVC及び左 CIV 径はステント群で $14.4 \pm 2.6 / 3.3 \pm 0.9 \mathrm{~mm}$, 非ステント群で 16.7 $\pm 2.6 / 7.7 \pm 3.0 \mathrm{~mm}$ で左 CIV 径はステント群で有意に小さかった $(\mathrm{p}<0.05)$ 。平均観察期間は660.5 \pm 541.2 日で全例に抗凝固剂が投 与され，10例は下肢症状消失，2例で大腿膝窩静脈に残存血栓に よる下腿浮腫を軽度認め, 全て非ステント留置例であった。考 案：左AIFVOに対するカテーテル治療を行う際には, DVTの 原因としてMTSを疑い，ステント留置を考慮する必要がある。 その際にCTでの左 CIV 径の計測は有用かもしれない。今回の 検討では, 左CIVに留置したステントの慢性期開存率は良好で あった。

Key words : DVT, CDT

\section{0-20-3 当施設における腕頭静脈閉塞 4 例に対する血管 内治療の経験}

総合高津中央病院

○吉田善紀, 宮本 明, 高木友誠, 丸山 高, 久原亮二, 秋田孝子, 福田正浩, 山内靖隆

腕頭静脈閉塞は静脈高血圧の原因となり，透析シャント肢では 著明な上肢浮腫を生じる。今回, 当施設で腕頭静脈閉塞に対し て血管内治療（EVT）を実施した4例について報告する。4例の 平均年齢は64.5歳で, 男性2例, 女性2例。4例中3例が透析症例で あった。症例1は，62歳女性。腎不全により12年前より維持透析 中。8年前よりの左上肢の浮腫, 肩痛を自覚し受診。CTにて左 腕頭静脈閉塞を認め, EVTを施行。ガイドワイヤを貫通させた 後, 自己拡張型ステント $10.0 / 60 \mathrm{~mm}$ を留置した。症例 2 は, 84 歳 女性。腎硬化症による慢性腎不全のため, 4年前より透析療法中。 左上肢，および胸部の浮腫を認め，1年前他院にて左腕頭静脈閉 塞に対してEVTを施行 (自己拡張型ステント9.0/80mm 留置)。 治療後症状改善していたが, 再燃あり受診。CT 上左腕頭動脈の ステント内閉塞が疑われ，EVTを施行。ガイドワイヤを貫通し た後ステント内に自己拡張型ステント10.0/6mmを留置した。症 例3は, 55歳男性。慢性系球体腎炎のため7年前透析療法中。左 上肢の浮腫, 発赤症状のため受診。CTにて左腕頭静脈閉塞を認 め, EVTを施行。ガイドワイヤを貫通させた後, 自己拡張型ス テント10.0/60mm を留置した。症例4は, 57歳男性。生体腎移植 後, 腎機能障害を有している。左上肢浮腫のため, 受診。CTに て左腕頭静脈から左鎖骨下静脈にかけて閉塞を認めた。ガイド ワイヤを貫通した後, 自己拡張型ステント $10.0 / 80 \mathrm{~mm}$ を2本重ね て留置した。4例ではいずれも治療後, 顕著な浮腫等の症状改善 を認めた。また，2例で遠隔期の再治療を要した。文献的考察を 加えて報告する。

Key words : EVT, Brachiocephalic vein occlusion

\section{0-20-4 難治性下腿潰瘍に対して下腿静脈弁の形成術や 腋下静眽弁の移植により改善した外科的治療の得策}

${ }^{1}$ 國際先端総合医療研究所、外科, ${ }^{2}$ 兵庫県立淡路医療セン ター、心臓血管外科, ${ }^{3}$ 加古川中央病院、外科

$\bigcirc$ 岡田昌義 ${ }^{1}$, 杉本貴樹 ${ }^{2}$, 久野克也 ${ }^{3}$

はじめに：最近, 我が国では, 難治性潰瘍が増加の一途を辿っ ている。これらには, 硬化療法, レーザー治療, 静脈弁形成術 や静脈弁移植術なども行われている。今回, これらの内, 静脈 弁形成術と静脈弁移植術について外科治療を行った成果につい て報告する。対象と方法：過去16年間で330症例の下肢静脈瘤と 難治性下腿潰瘍に外科手術を行ってきた。そのうち，31例に対 して下肢静脈の弁形成術と静脈弁移植術を行った。31症例は, 男性12例, 女性19例であり, 平均年齢は, 59歳であった。これ らの症例は，何年もの間下腿潰瘍に悩まされていたのであるが, すべての症例に下行性静脈造影, 静脈圧測定, 内視鏡検查など と共に, 潰瘍の大きさや深さなどを測定した。弁形成術の際に は, この弁の直上で黄切開して, 前後 2 枚の弁を検索して, こ れらが接合するようにどちらかの弁を引き上げて調節した。そ の後,内視鏡下に観察を行い，2枚の弁が接合しているのを確認 した。一方, 弁の移植術の場合には, 腋下静脈の弁を含めて管 状に切除して使用した。成績：以上，行った結果は，弁形成術 を行った 23 例の症例では, 満足すべきものであった。また, 残りの弁移植を行った 8 症例では, すべて満足すべきものであっ た。すべての症例は, 全例生存しており, 日常生活に全く不便 なことは見られない。考察と結論：静脈弁形成術と弁移植を行っ た症例は，全例が活動しており，全く不憫さは見られていない。 下肢の下行性静脈造影と血管内視鏡は, 必須であると同時に, 外科手術の良否の判定に必須であった。静脈弁の形成術と腋下 静脈弁移植術を使用することによって, 今までにない成果を上 げることができた。

Key words : valve recontraction, valve transplantation

\section{0-20-5 当院で経験したPaget-Schroetter症候群の 6 例} 製鉄記念広畑病院 血管外科

$\bigcirc$ 福岡正人

Paget-Schroetter 症候群は, 上肢に発症する深部静脈血栓症で, 比較的稀な疾患である。Costoclavicular spaceで受ける圧迫, 過度の労作による静脈損傷から血管閉塞をきたした静脈性胸郭 出口症候群と考えられている。今回, 当院でPaget-Schroetter 症候群を6例経験したので, 若干の文献的考察を加え報告する。 過去20年で当院血管外科を受診し, Paget-Schroetter症候群と診

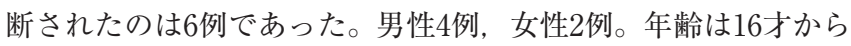
62 才平均 $35.7 才$ ) であった。患肢は右が3例，左3例。主訴は全 例上肢の腫張で来院されていた。過度な運動, 労作が原因と判 明されたのは5例で，原因が不明であったのは1例であった。治 療法は, 入院5例にウロキナーゼ, ヘパリンの血栓溶解療法 +抗 凝固療法が行われ，引き続き，4例でワーファリン内服による抗 凝固療法を，1例でDOACによる抗凝固療法が継続された。残 りの1例は外来でDOACによる抗凝固療法を行った。全例で症 状の改善が認められた。いずれも血栓溶解による症状改善目的で, 
胸郭出口症候群の根本治療の一つである, 第一肋骨切除などの 外科的手術や, ステント留置などは行なっていない。当院で経 験したPaget-Schroetter 症候群を報告した。比較的まれな疾患 でり，定まった治療法があるわけではないが，今後，DVTの治 療薬 DOACの普及により, Paget-Schroetter 症候群の治療法の 選択にも広がる可能性があると考えられる。

Key words : Paget-Schroetter syndrome, Upper extremity DVT

\section{0-21-1 当院における肺血栓塞栓症に対する治療の変遷}

鳥取県立厚生病院 血管外科

$\bigcirc$ 児玉 渉, 西村謙吾, 浜崎尚文

【諸言】静脈血栓症（VTE）治療は未分画へパリン併用によるワ ルファリンでの抗凝固療法が施行されてきたが,2014年9月から 経口抗凝固薬（DOAC）がVTE治療に適応となり,必ずしもへ パリンを必要としなくなった。今回当科における肺血栓塞栓症 (PTE) に対する治療を後方視的に検討した。

【対象】2010年1月～2019年12月に当院でPTEと診断し, 初期治 療を行った91例を,DOACを導入した2015年11月以降（A群;43 例）とそれ以前（B群;48例）とで治療成績を比較した。

【結果】性別; 女55例, 男36例。平均年齢70.8歳。発見契機（重複 あり）;下肢浮腫腫脹 41 例, 呼吸苦 22 例, 他疾患精査中 17 例, ショッ ク状態 10 例, 胸痛 3 例。背景因子（重複あり）; 悪性腫瘍 23 例, 脱水 13 例, 長期臥床 11 例, ホルモン治療 11 例, 手術後 8 例, 凝固異常疾患 6 例, VTEの既往;4例, その他 13 , 不明 9 . 入院加療を要したのは77例 (A 群/B群;30/47）で,平均入院期間は30.7日（A/B;27.7/32.7）, ICU 入室例 $(A / B ; 8 / 10)$ であった。下肢深部静脈血栓症の合併 は A 群32例,B群42例であった。ESCガイドラインの急性期死亡 リスクに応じた重症度分類 High (H) /Intermediate-High (I-H) /ntermediate-Low/Low の症例数は, A;4/5/21/13,B;4/9/21/14 で,Hと I-H患者は全例へパリンを使用した。初期治療でのへパ リン使用例は $\mathrm{A} / \mathrm{B} ; 24 / 45$, 血栓溶解療法併用例は $\mathrm{A} / \mathrm{B} ; 3 / 12$ であっ た。ワルファリン使用例 $\mathrm{A} / \mathrm{B} ; 7 / 45, \mathrm{DOAC}$ 使用例 $\mathrm{A} / \mathrm{B} ; 35 / 0$. IVCフィルター留置例は,A/B; $0 / 14$. 在院死例は $\mathrm{A} / \mathrm{B} ; 2 / 3$ だった がPEによる在院死は B 群1例であった。出血性合併症は $\mathrm{A}, \mathrm{B}$ 群 ともに入院中に発症し,A群3例,B群2例であった。

【結語】 DOAC 治療は入院期間が短縮でき,外来治療が容易であっ たが,A群B群ともにPTEに起因した予後に差は無かった。

Key words : Pulmonary thromboembolism, Direct Oral Anticoagulants

\section{0-21-2 術前PCPSを必要とした急性肺塞栓症に対し緊 急血栓摘出術を施行した 2 例}

小牧市民病院 心臓血管外科

○泊 史朗, 澤崎 優, 藤井太郎, 植村友稔

急性肺塞栓症は重篤な疾患で救命のためには迅速で適切な治療 が必要となる。今回我々は, 急性肺塞栓症により心肺停止を来し た2症例に心肺蘇生, PCPS 補助を行い, 緊急人工心肺下血栓摘 出術を施行し良好な結果を得たので報告する。

【症例1】44歳, 女性。心筋炎の診断で入院加療が行われていた。
入院3日目より離床開始となったが, 4 日目に意識消失発作, 呼 吸困難感が出現し, 造影 CTにて両側肺動脈に広範な血栓像を認 め, 急性肺塞栓症の診断となった。CT後に呼吸停止となり, 心 肺蘇生およびPCPS 開始となったため, 緊急血栓摘出術を行う こととした。胸骨正中切開後にPCPSを通常の人工心肺に変更し, 心停止下に両側肺動脈をそれぞれ切開し，血栓を摘出した。大 動脈遮断解除後も心収縮不良で, 再度PCPSに変更し手術を終 了した。術後第1病日にPCPS 離脱，第10病日に人工呼吸器離脱。 PCPS 送血管挿入側の右下肢に運動障害を来たしたため, リハビ リ目的に第58病日に転院となった。

【症例2】55才, 女性。外出時に呼吸困難感が出現し, 当院救急 搬送となった。来院後に意識消失, 心室細動となり心肺蘇生, PCPS 開始となった。心エコーにて右室の著明拡張と左室虚脱を 認め, 造影 CTにて両側肺動脈に広範な血栓像を認めたため急性 肺塞栓症の診断となり, 緊急血栓摘出術を行うこととした。胸 骨正中切開後にPCPSを通常の人工心肺に変更し, 心拍動下に 両側肺動脈をそれぞれ切開し血栓を摘出した。心収縮不良なため, 再度PCPSに変更し手術を終了した。術後第3病日にPCPS 離脱, 第6病日に人工呼吸器離脱,第25病日に独歩転院となった。 Key words : APE, PCPS

\section{0-21-3 心不全既往と急性肺塞栓症の院内予後の関係〜 東京都CCUネットワークデータベースからの解析}

${ }^{1}$ 武蔵野赤十字病院, ${ }^{2}$ 東京都 CCU ネットワーク学術委員会 $\bigcirc$ 野里寿史 ${ }^{1}$, 山本 剛 ${ }^{2}$, 水野 篤 ${ }^{2}$, 間淵 圭 $^{2}$, 村田哲平 ${ }^{2}$, 久武真二 ${ }^{2}$, 正司 真 $^{2}$, 原 信博 ${ }^{1,2}$, 辻田裕昭 ${ }^{2}$, 長尾 建 $^{2}$, 高山守正 ${ }^{2}$

【背景】急性肺塞栓症には右心負荷・右心不全を合併することも あり, 重症例では予後も悪い。このような中, 心不全の既往が 急性肺塞栓患者の院内予後に与える影響は不明である。

【目的】心不全既往と急性肺塞栓の院内予後について検討を行う。 【方法】東京都CCUネットワークのデーターベース（2013年〜 2017年）を用い, 心不全既往を含めた患者背景, 入院時検査所 見と院内予後を後ろ向きに解析した。

【結果】総症例数1972例中, デー夕使用可能な1950例（男性880 例, 女性1070例）を解析対象とした。平均年齢66 016 歳, 院内死 亡は74例（4\%）だった。高血圧 797例 (41\%), 脂質異常症379 例 $(19 \%)$, 糖尿病 241 例 (12\%), 心不全既往30例 (1.5\%), 来 院時収縮期血圧 $129 \pm 44 \mathrm{mmHg}, \mathrm{Cr} 0.81 \mathrm{mg} / \mathrm{dl}$ (中央值), BNP $115 \mathrm{pg} / \mathrm{ml}$ (中央值) であった。来院時の臨床重症度別では, 非 広範型 (血行動態安定) 922例 $(47 \%)$, 要広範型（右心機能不 全のみ) 768 例 $(39 \%)$, 広範型（ショックなど血行動態不安定） 155例 (8\%), 循環虚脱78例 (4\%) であった。心不全既往群と 対照群では, 来院時血圧や BNPに有意差はなく, Cr は有意に高 值であった (1.29 vs. $0.91 \mathrm{mg} / \mathrm{dl}, \mathrm{p}=0.0183) 。$ カプランマイヤー 解析では心不全既往患者の 30 日生存率は対照群と比較し有意に 低值であった（81\% vs.94\%, log-rank, p=0.0029）。

【結論】心不全既往のある急性肺塞栓患者の院内予後は悪い。急 性肺塞栓では右心負荷に伴い, 心機能への影響もあるため, 問 診による心不全の有無の確認は重要である。 
Key words : pulmonary embolism, heart failure

\section{0-21-4 慢性血栓塞栓性肺高血圧症における肺動脈血栓 内膜摘除術後の残存肺高血圧に対するバルーン肺動脈形成 術の治療効果の検討}

${ }^{1}$ 国立循環器病研究センター 心臟血管内科, ${ }^{2}$ 国立循環器 病研究センター 心臟血管外科

○岩永光史 ${ }^{1}$, 青木竜男 ${ }^{1}$, 大郷 剛 $^{1}$, 辻 明宏 $^{1}$,

上田 仁 $^{1}$, 中山小百合 ${ }^{1}$, 浅野遼太郎 ${ }^{1}$, 井上陽介 ${ }^{2}$,

上原京勲 ${ }^{2}$, 佐々木啓明 ${ }^{2}$, 松田 均 ${ }^{2}$, 安田 聡 $^{2}$

【背景】肺動脈血栓内膜摘除術（PEA）は慢性血栓性肺高血圧 症（CTEPH）に対する外科的治療として確立されているが,一 部の症例で術後に肺高血圧症が残存する。近年, 非手術適応の CTEPH 症例に対するバルーン肺動脈形成術（BPA）の有効性 が報告されており, 本研究ではPEA後に肺高血圧症が残存した 症例に対するBPAの治療効果を検討した。

【方法と結果】当院で2010年10月から2019年2月にPEAが施行 された 227 症例のうち55症例が術後残存肺高血圧症（肺動脈圧 $(\mathrm{mPAP}) \geqq 25 \mathrm{mmHg})$ を呈し，その中でBPAが施行され，治療 終了3か月後に右心カテーテル検查が施行された29症例（平均年 齢 55歳, 男性 6名 $(21 \%)$ ) を本研究の対象とした。PEAから 初回BPA までの期間の中央値は42 [13.5, 94] か月で, BPAは1人 当たり平均 $5.5 \pm 1.5$ 回施行された。 $\mathrm{BPA} よ り \mathrm{mPAP}(\mathrm{BPA}$ 前： $38 \pm 10$, 後 $: 27 \pm 8 \mathrm{mmHg}), \mathrm{PVR}(9.2 \pm 4.6,5.1 \pm 2.2 \mathrm{WU})$ およ びRVEF（38.4 $56.8,44.2 \pm 7.1 \%$ \%) は有意に改善した（いずれも $\mathrm{P}<0.01)$ 。また, 6 分間歩行距離 $(393 \pm 125,452 \pm 125 \mathrm{~m}, \mathrm{p}<0.01)$ 掞よび最大酸素摂取量 $(16.4 \pm 3.8,18.1 \pm 4.6 \mathrm{ml} / \mathrm{min} / \mathrm{kg}, \mathrm{p}<0.05)$ も有意に増加した。BPA手技に関連する死亡や人工呼吸器管理 を要する合併症は認めなかった。

【結論】PEA後に肺高血圧症が残存する CTEPH症例において， BPA は重大な合併症なく, 血行動態, 右室収縮能捥よび運動耐容 能を改善し, 効果的な治療選択肢となり得ることが示唆された。 Key words : Chronic pulmonary hypertension, Balloon pulmonary angioplasty

\section{0-21-5 リバーロキサバンを用いた深部静脈血栓症及び 肺血栓塞栓症に対する実臨床下における安全性、有効性： 特定使用成績調査中間報告}

${ }^{1}$ リバーロキサバン PE/DVT 適正使用委員会, ${ }^{2}$ バイエル薬 品株式会社 メディカルアフェアーズ\&ファーマコビジラ ンス本部, ${ }^{3}$ バイエル薬品株式会社 研究開発本部 ○山田典一 ${ }^{1}$, 福田幾夫 ${ }^{1}$, 平山篤志 ${ }^{1}$, 小林隆夫 ${ }^{1}$,

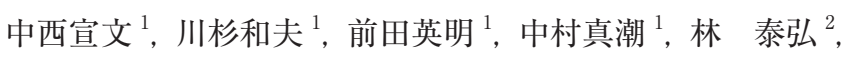
田島 翼 $^{2}$, 岩城相憲 ${ }^{2}$, 岡山 豊 $^{2}$, 砂谷敏行 ${ }^{3}$, 平野和史 ${ }^{2}$, 山中 聡 $^{2}$

選択的直接作用型第Xa因子阻害薬リバーロキサバンは, 2015年 9月に「深部静脈血栓症及び肺血栓塞栓症の治療及び再発抑制」 の効能・効果が追加された。本特定使用成績調查は, 深部静脈 血栓症（DVT）及び肺血栓塞栓症（PTE）患者を対象とした本 剂使用実態下に扔ける安全性, 有效性情報の収集を主目的とし
た前向き登録観察研究である。2018年3月に登録期間が終了し， 2540 例が登録された。現在投与開始から $1 ， 3 ， 12$ 抒よび24力月 の時点に扔ける情報を集積中である。2019年9月15日までに固 定された2171症例のデー夕を用いて, 患者背景, 安全性, 有効 性に関する報告を行う。主な患者背景は, 年龄 $66.8 \pm 15.1$ 歳, 男 性 $41.5 \%$, 体重 $60.9 \pm 14.0 \mathrm{~kg}$, クレアチニンクリアランス $82.8 \pm$ $36.8 \mathrm{~mL} / \mathrm{min}$, 治療開始時にPTEを有していた割合が $49.6 \%$, 観 察期間は255.3 2527.9 日であった。安全性解析対象 2162 例のうち, 出血性有害事象は164例（7.6\%), 重大な出血（ISTH 基準）の 有害事象は65例（3.0\%）であった。有効性解析対象2161例のう ち, PTE/DVTの再発は42例 $(1.9 \%)$ であった。本報告では, 初期治療, 維持治療導入例の特徵, PTE/DVT 発症後初期 3 週間 の服薬状況, 高リスク患者に扔ける安全性・有効性イベントの 発現状況等も併せて報告する。今回の中間報告は, 安全性の新 たな懸念事項がないことを示唆するものである。(JPMS-XARVTE: ClinicalTrials.gov, NCT02558465)

Key words : venous thromboembolism, anticoagulant therapy

\section{0-22-1 ICGリンパ管造影による集合リンパ管の同定率： 下肢リンパ浮腫 840 部位での包括的検討}

国立国際医療研究センター病院 形成外科

○坂井勇仁, 景山貴史, 十九浦礼子, 山本 匠

【背景】インドシアニングリーン（ICG）リンパ管造影はリンパ 浮腫の評価法として広まりつつある。特に, リンパ管細静脈吻 合（LVA）に扔いて，吻合用のリンパ管同定法として最も有用 な検查として確立されつつある。リンパ管同定率に関する文献 は散見されるものの, 多数の症例を基にした包括的な検討はな されていなかった。

【方法】二次性下肢リンパ浮腫134例に対して行われたLVAにお いて, 術中リンパ管同定率を検証した。術前ICGリンパ管造影 所見から Linear/Splash-Stardust/Diffuseパターンを呈するL/S/ $\mathrm{D}$ 領域に分類した。年齢（65歳未満vs以上), 放射線既往（無 vs 有), 蜂窝織炎 (無vs 有), 浮腫（5年未満vs以上), BMI ( 25 $\mathrm{kg} / \mathrm{m}^{2}$ 未満vs 以上), 部位( 鼠径vs大腿vs下腿vs足背), 造影 所見（L領域vs S 領域 vs D 領域）を独立変数とし，ロジスティッ ク回帰分析によりリンパ管同定と関連のある因子を調べた。

【結果】 LVAは840箇所に施行され，807箇所 $(96.1 \%)$ でリ ンパ管が同定された。L領域におけるリンパ管同定率は $100 \%$ (288/288) であった。多変量解析の結果, 高BMI（オッズ比 $0.323, \mathrm{P}=0.008$ ） および造影所見 $\mathrm{S}$ 領域 $/ \mathrm{D}$ 領域（オッズ比とも に<0.001，P值ともに<0.001）が低リンパ管同定率に関連した 独立因子であった。

【考察】低BMI症例㧍よびICGリンパ管造影でLinearパターン 部に执いて,リンパ管同定率が有意に高いことが示された。特 にICGリンパ管造影は，L領域においてリンパ管同定率が100\% であり，従来より報告されているLVA 手術における術前マッピ ング・術中ナビゲーションとしての有用性が裏付けられた。

Key words : Lymphedema, Supermicrosurgery 


\section{0-22-2 超音波検查による皮膚厚測定の四肢リンパ浮腫診 断での有用性に関する検討 : 健康成人の四肢皮膚厚の特徵}

仁鷹会 たかの橋中央病院 血管外科

$\bigcirc$ 春田直樹，赤羽慎太郎

【目的】四肢リンパ浮腫症例の患肢の超音波所見は皮下脂肪織内 のリンパ液貯留と，皮膚肥厚が特徴的である。リンパ液貯留は 治療により軽隇変化するが，皮虚肥厚に関しては治療抵抗性で ある。この点に注目し超音波検查による皮虐厚測定の四肢リン パ浮腫診断での有用性に関し検討した。第1 1 報研究として健康成 人の四肢皮膚厚の特徴を検討した。

【対象】健康成人男性17名女性17名の合計 34 名で四肢皮膚厚測定 を行った。

【方法】使用した超音波診断装置は周波数 $18 \mathrm{MHz}, \mathrm{B}$ モード, 電子リニアースキャン方式プローベ (EUP-L75)，HI VISION (Avius Hitachi Medical Corporation, Japan) を用いた。具体的 な皮虐厚計測は，保存した2次元グレースケール画像で $5 \mathrm{~mm}$ 押 きに連続する3力所で皮膚厚を測定し，その平均值を測定部位で の皮虚厚とした。測定は上肢・下肢ともに四肢リンパ浮腫症例 で周径測定を行う部位に準じて上肢では上腕部，前腕部，手関 節部の左右 12 力所で測定し，下肢では大腿部，下腿部，足関節 部左右12カ所で測定した。

【結果と結語】上肢・下肢ともに，3力所の測定点において内側 に比較し外側が有意に肥厚しており，また下肢では内外側とも に末梢側ほど皮虐厚が厚いことを初めて報告した。また従来の 報告通り，皮虐厚には性差があることから，今後四肢リンパ浮 腫症例での皮虐厚を測定し，健康成人と比較する場合，性別の 一致と測定点に扔ける内側・外側の部位も一致させた比較が必 要であることが判った。

Key words : lymphedema, echography

\section{0-22-3 僧帽弁再手術後の縦隔リンパ漏に対してリピオ ドールリンパ管造影が有効であった 1 例 \\ 北海道大野記念病院}

○伊藤寿朗, 大堀俊介, 鈴木正人, 森本清貴, 横山秀雄, 大川洋平

症例は71歳の女性。糖尿病と慢性腎不全の既往があった。僧帽 弁形成術㧍よび三尖弁綘縮術の5力月後に僧帽弁前尖に疮贅を伴 う感染心内膜炎を発症し僧帽弁置換術が施行された。術後心囊 ドレーンより $300-600 \mathrm{ml} /$ 日の排液を認め, 食事摃取が始まる と乳白色に混濁したため縦隔リンパ漏と診断した。絶食と高力 ロリー輸夜を 2 週間継続したほか, ソマトスタチンの皮下注を連 日行ったが改善を認めなかったために, 術後37日目にリピオドー ルリンパ管造影を施行した。左鼠経に局所麻醉を行い，エコー ガイド下にリンパ節を穿刺し $12 \mathrm{ml} /$ 時の速度で約1時間リピオドー ルを持続注入した。術翌日よりドレーン量が減少し、リンパ管 造影施行後6日目に心囊ドレーンを抜去することができた。僧帽 弁再手術後の縱隔リンパ漏に対してリピオドールによるリンパ 管造影を施行し改善した症例を経験したので，文献的考察を加 え報告する。

Key words : taiki555, taiki555

\section{0-22-4 左無名静脈閉塞解除が寄与した乳び胸の症例}

日本赤十字社医療センター

○西村潤一, 原田明典, 内山史也, 山田哲久

症例は, 大動脈術後の患者。2年前にA型大動脈解離に対し全 大動脈弓部置換術が施行されていた。今回は偽沿拡大に対し下 行大動脈置換術が施行された。その直後から生じた乳び胸に対 して経静脈的逆行性胸管造影並びに胸管（TD）塞栓術（TDE） が計画された。左無名静脈閉塞は下行大動脈置換術並びに経静 脈的逆行性胸管造影前の造影 CT で確認されていた。経静脈的逆 行性胸管造影については充分な cannulation ができなかったた め, 不成功に終わったが, 左無名静脈の cannulation が可能で あったため, そのままバルーン拡張を行い, 再開通には成功し た。この後, リンパ瘦は減少し, 乳び胸は収束した。TDEは乳 び胸に対して一般的に受け入れられている治療法となっている。 TDE リンパ流の生理的経路を少なからず破綻させる。我々は過去に リンパ管結紫後 20 年経ってから生じた両側性肺のリンパ浮腫 の症例を経験している。このような遅れた合併症を避けるため には，生理学的リンパ流を確保することも考慮すべきではない かと考えている。一方，TDからのリンパ漏の減少させることが, 乳び胸の治療においては完全TDEよりも重要と考えられている。 今回静脈閉塞により増大したリンパ管の後負荷を静脈閉塞解除 することで, TDからのリンパ漏の減少に成功し, 結果として乳 び胸の治療が成り立ったものと考えられた。

Key words : Chylous Pleural Effusion, innominate vein obstruction

\section{0-22-5 大動脈手術後リンパ漏に対するintra-nodal lymphangiographyによる 162 例の治療成績}

社会医療法人財団 石心会川崎幸病院川崎大動脈セン 夕一 血管内治療科

○長谷聡一郎, 中川達生, 鹿島正隆

【目的】大動脈手術後のリンパ漏に対して intra-nodal lymphangiography（INL）による治療成績を検討した。

【方法】対象は2013年6月から2020年3月まで大動脈の open surgeryを施行した3927例のうち術後リンパ漏に対して INL を施行した162例（4.1\%）。平均年齢66.4歳（24-92）,男性 119 例 $(73.5 \%)$ 。対象疾患は大動脈瘤70例 (43.2\%), 大動脈解離89 例 $(54.9 \%)$ ，之の他 3 例 $(1.9 \%)$ 。術式は大動脈弓部置換19例 (11.7\%），下行置換51例（31.5\%），胸腹部置換91例（56.1\%）, 腹部置換 1 例 $(0.6 \%)$ 。手術-INL 施行までの間隔0-603日（中央値 6日)。INL手技はUSガイド下に23ゲージカテラン針で鼠径部リ ンパ節を穿刺しヨード化ケシ油脂肪酸エチルエステル（リピドー ルR）を用手的に緩徐に注入した。検討項目は手技に伴う合併症， 手技的成功率, 臨床的成功率。INLにより腸骨節レベルのリンパ 管が描出されたものを手技的成功,INLで外科的追加治療なくリ ンパ漏改善を認めたものを臨床的成功とした。

【結果】手技的成功率 $94.4 \%$, INLに対する使用リピオドール量は 平均 $18.4 \mathrm{ml}(6-40 \mathrm{ml})$ 。臨床的成功率 $82.7 \%$ 。複数回の INLで改 善11例（6.8\%），追加外科的治療12例（7.4\%)。他因子による院 
内死亡4例 $(2.5 \%)$ 。合併症は呼吸器管理を要する呼吸困難1例 $(0.6 \%)$ ，一過性の酸素化不良1例 $(0.6 \%)$

【結論】INLは大動脈手術後リンパ漏の治療としても安全かつ有 用な方法であると考えられる。

Key words: INL, chylo-leakage

\section{0-22-6 加齢性リンパ浮腫へのリンパ管静脈吻合}

広島大学病院 国際リンパ浮腫センター

吉田周平, 光嶋 勲, 今井洋文

【目的】加齢によりリンパ管機能が低下する事が一因となって原 発性リンパ浮腫を発症する事がある。本研究では加齢性リンパ 浮腫に対しリンパ管静脈吻合術を行い加齢性リンパ浮腫におけ るリンパ管の特徴とリンパ管静脈吻合術の効果を調べた。

【方法】対象は 74 名 136 肢の30歳以降発症の原発性下肢リン パ浮腫でICGリンパ造影後にリンパ管静脈吻合を施行した。術 中のリンパ管径とリンパ管同定率を調査した。術前後のリンパ 浮腫改善率も調査した。

【成績】両側性にリンパ浮腫を認めた患者は 62 例, 片側性は 12例であった。両側性（bilateral）に浮腫を認める患者は片側 性（unilateral）に認める患者に比べ有意に高齢であった（77.1 \pm 7.8 years vs $55.5 \pm 12.77$ years; p<0.01)。両側性の I C G 所 見は 4 系に分類でき, ICG 造影所見はlinearが下肢全長に観 察される linear群, 下肢で linearも diffuse も観察できない low enhancement（LE）群，末梢にdermal back flowを認める dDB 群，下腿大腿両方にdermal back flow 認める eDB群に分類で きた。リンパ管径の群間比較は有意差が見られ, 術後のリンパ 浮腫の改善度の群間比較でも有意差が見られた。

【結論】リンパ管径は両側性が片側性に比べより拡張傾向を示し ていた。両側性の中でも dermal back flow パターンが広がる群 ほどリンパ管の拡張傾向は減少しリンパ管静脈吻合術後の改善 率も減少傾向にあった。両側性は加齢性原発患者に多い特徴で dermal back flow パターンが広がらないlinear パターンが見ら れる症例ほど改善率が良かった。加齢性原発患者でもリンパ管 静脈吻合で改善させる事ができ，より早期に行う方が結果が良い。 Key words : lymphedema, aging

\section{0-23-1 血管型Ehlers-Danlos症候群患者 19 例の臨床 経過 : 大動脈腹部分枝動脈の瘤・解離に注意せよ}

${ }^{1}$ 日本医科大学 循環器内科, ${ }^{2}$ 日本医科大学 遺伝診療科 $\bigcirc$ 圷 宏一 ${ }^{1}$, 渡邊 淳 $^{2}$, 山田岳史 ${ }^{2}$, 清水 涉 $^{1}$

【目的】血管型Ehlers-Danlos 症候群（vEDS）は Ehlers-Danlos 症候群の1亜型であり，希少疾患であるがその予後は極めて不良 でありその寿命の中間值は51歳と報告されている。しかしその 臨床経過は十分に知られていない。我々はvEDS患者19例の臨 床経過を報告する。

【方法】対象はvEDSと確定診断された19例（COL3A1異常 18 例：typeIII コラーゲン産生低下1例）でその臨床経過を検討した。 【結果】（1）当科への紹介時点の年齢（中央值34歳,18-67歳）。 院の必要なEvent発症時の年齢 (中央值30歳, 14-42歳)。観察期 間（中央值56か月，12-116か月)。（2）最終観察時までの次の問
題を生じた人数：腹部分枝動脈瘤・解離・破裂11（58\%）, 腹部 分枝以外の動脈瘤・解離・破裂7 (37\%), 大動脈瘤・解離1 (5\%), 血気胸4 (21\%), 腸管穿孔6 (32\%), 子宮破裂0であった。(3) さらに腹部分枝動脈における解離・瘤・破裂ののべ数は29（CEA 分枝6, SMA 分枝5, 腎動脈 4 , 腸腰動脈 1 , 総腸骨動脈8, 内腸 骨動脈 0 , 外腸骨動脈5), 腹部分枝動脈以外における解離 - 瘤 破裂ののべ数は9（脳動脈2, 内頸動脈3, 冠動脈1, 肋間動脈2, 椎骨動脈1）であった。(4) 死亡は3（16\%）（CEA分枝破裂, 総 腸骨動脈破裂, 肋間動脈破裂の疑い)。

【結論】vEDSはMarfan 症候群, Loeys-Dietz症候群などの遺伝 性結合織疾患に分類されるが，その病変は大動脈ではなく腹部 大動脈分枝動脈，特に腸骨動脈領域に集中している。若年患者 の腹部分枝動脈の Eventに遭遇した場合には, その原因として vEDS 合併の可能性を検討するべきである。

Key words : vascular Ehlers-Danlos syndrome, arterial aneurysm

\section{0-23-2 若年者における中小動脈破綻症例の特徵}

東京大学医学部附属病院 血管外科

○福原菜摘, 保科克行, 露木翔太, 遠藤貴士, 前野竜平, 花田和正, 大片慎也, 大橋雄一, 佐野允哉, 宮原和洋, 松倉 満, 赤井隆文, 伊佐治寿彦, 高山利夫

【目的】動脈瘤や動脈解離といった動脈の壁構造の破綻をきたす 疾患は, 動脈破裂につながり致命的となりうるため, 適切な治 療介入が必要である。多くは動脈硬化による血管壁の脆弱化が 原因であるが, 感染や炎症, 遺伝子疾患など, 動脈硬化の寄与 しない血管破綻もあり治療アプローチが異なるため, 適切な診 断と治療方針の決定が必要である。今回我々は動脈硬化要素の 少ない若年者における動脈破綻症例について, その内訳と経過 から特徵を検討した。

【方法】当院での診療記録から，1995年から2019年の間で当科に おいて診療を行った患者のうち, ”大動脈“を除く”動脈瘤“, ”動 脈解離“, ”動脈損傷“, ”動脈破裂“の病名が付くものを抽出した。 合計 926 人, 1197 病変が抽出された。そのうち, 50 歳未満の 108 人, 172病変について内訳と経過を検討した。

【結果】年齢は11歳から49歳までであり, 外傷・医原性 21 症例 21 病変, 感染 2 例 2 病変, 膵炎 3 例 3 病変, 弓状靱带症候群 4 症例5病変, 動静脈奇形 2 例 2 病変, 血管炎8症例 22 病変, 遺伝性疾患7症例 33 病変, fibromuscular dysplasia 1症例1病変, segmental arterial mediolysis 4症例11病変, 単発瘤または解離49症例53病変, 原 因不明多発瘤または解離7症例19病変であった。多発病変を有 するものが50歳未満では25例（28\%）であり，50歳以上の148例 (18\%）よりも多い比率であった。なかでも，血管型エーラスダ ンロス症候群 4 例中 3 例, ベーチェット病 4 例中 4 例で複数病変を 有しており, 手術回数も多かった。

【結論】若年における動脈破綻は多発例と手術加療を繰り返すも のが多かった。若年で多発動脈病変を認める場合には, 遺伝子 疾患あるいは血管炎を鑑別に挙げる必要がある。

Key words : arterial deterioration, aneurysm 


\section{0-23-3 急性下肢動脈閉塞症を繰り返し、肺血栓塞栓症 を発症した本態性血小板血症の一例}

${ }^{1}$ 岩手県立中央病院 循環器内科, ${ }^{2}$ 岩手県立中央病院 心 臓血管外科, ${ }^{3}$ 岩手県立中央病院 血液内科, ${ }^{4}$ 岩手県立中 央病院 病理診断科

○安達 歩 $^{1}$, 三浦正暢 ${ }^{1}$, 内村久美 ${ }^{1}$, 薄田 海 $^{1}$, 畠山翔翼 ${ }^{1}$, 山田祐資 ${ }^{1}$, 山田魁人 ${ }^{1}$, 加賀谷裕太 ${ }^{1}$, 佐藤謙二郎 ${ }^{1}$, 齊藤大樹 ${ }^{1}$, 金澤正範 ${ }^{1}$, 近藤正輝 ${ }^{1}$, 小田克彦 ${ }^{2}$, 佐藤彰宜 ${ }^{3}$, 佐熊 勉 $^{4}$, 遠藤秀晃 ${ }^{1}$, 中村明浩 ${ }^{1}$ 【症例】81歳, 女性

【現病歷】 $\mathrm{X}$ 年 $\mathrm{Y}$ 月 $\mathrm{Z}$ 日, 左下肢の色調不良と疼痛を認めたため 当院受診。造影 CTで左総腸骨動脈の急性動脈閉塞症を認めたた め同日緊急血栓除去術を施行した。 $Z+1$ 日, $Z+8$ 日に再度同部 位の急性動脈閉塞を認め緊急血栓除去術を施行し, $Z+10$ 日に 末梢血管形成術を施行した。入院時より血小板数 58.8 万 $/ \mu 1$ と 上昇認めていたため, Z+ 5 日に骨䯣穿刺を施行した。骨髄所見 は巨核球の增多を伴う過形成骨䯣であり, JAK2遺伝子変異陽性 であることから本態性血小板血症と診断し，アスピリン $100 \mathrm{mg} /$ 日，アナグレリド1.5mgによる加療を開始した。Z+21日呼吸苦 を発症し, 造影 $\mathrm{CT}$ 上深部静脈血栓症, および肺血栓塞栓症を認 めたためアピキサバン $20 \mathrm{mg} /$ 日の投与を開始し, Z+ 28 日より アピキサバン $10 \mathrm{mg} /$ 日へと隇量した。その後血栓症の発症なく, Z+64日リハビリテーションのため近医転院となった。

【考察】本態性血小板血症は，造血幹細胞レベルでの腫瘍化によ る骨髄增殖性腫瘍であり，生命予後は良好であるが，血栓症の 合併が問題となることが知られている。2018年の造血器腫瘍が イドラインでは, 60 歳以上, 血栓症の既往, JAK2遺伝子変異陽 性は高血栓リスクであることが報告されており，本症例におい ても血栓予防のため低用量アスピリン投与, 細胞減少療法の併 用を施行したが, 肺血栓塞栓症を発症した。本態性血小板血症 に対する静脈血栓予防のための抗凝固療法については出血り久 クが高く議論の余地がある。本症例では抗凝固薬の併用が血栓 予防に有用であったと考えられ, 若干の文献的考察を交え報告 する。

Key words : arterial occlusive disease, essential thrombocythemia

\section{0-23-4 右側大動眽弓に合併したKommerell瘜室の 2 治験例}

${ }^{1}$ 公立昭和病院 心臟血管外科, ${ }^{2}$ 公立昭和病院 放射線科 ○西野純史 ${ }^{1}$, 尾崎公彦 ${ }^{1}$, 宮原拓也 ${ }^{1}$, 荻原正規 ${ }^{1}$,

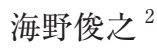

症例1は70歳男性。既往に胆石症, 左鼠径ヘルニアを有する。鼠 径ヘルニア術前精查にて縦郭陰影の拡大を指摘され, 当科紹介 受診。精查にて右側大動脈弓, 右側下行大動脈, Kommerell悡 室の診断となり手術加療の方針とした。自覚症状や心内奇形, 他の心血管疾患は認めなかった。手術は右後側方第 4 肋間開胸, 下半身部分体外循環にて悡室を含む下行大動脈置換術を予定し た。しかし, 中枢側遮断部の大動脈内膜損傷から低体温脳循環 停止, open proximal法で中枢側吻合を行った。術後経過は問題
なく, 19POD独歩退院。症例2は51歳女性。中国で出生し, 15 年ほど前より日本に在住している。特記すべき既往症なし。健 康診断にて施行した胸部 Xp にて異常除影を指摘, 胸部 CTに て大動脈奇形が疑われ当科紹介受診。右側大動脈弓, 右側下行 大動脈, 左鎖骨下動脈起始異常, Kommerell想室の診断となっ た。自覚症状なく, 心内奇形も認めなかった。手術は二期的手 術の方針とした。初回手術として, 胸骨正中切開で左鎖骨下動 脈胸腔内再建を伴う全弓部置換術, オープンステントグラフト 内挿術を行い, Kommerell㮩室はオープンステントグラフトで カバーした。悡室そのものは背側に位置し, 処理は行わなかっ た。15PODに Kommerell㮩室から左鎖骨下動脈起始部の塞栓 術を行った。術後経過は問題なく, 19POD独歩退院となった。 Kommerell想室は種々の手術方法が報告されている。文献的考 察を加え報告する。

Key words : Kommerell diverticulum, right aortic arch

\section{0-23-5 右側大動眽弓に伴うKommerell㮩室に対する 治療戦略}

湘南鎌倉総合病院 心臟血管外科

○片山郁雄, 長塚大樹, 服部 滋, 郡司裕介, 野口権一郎 【はじめに】右側大動脈弓にKommerell悡室（KD）を伴い，さ らに左鎖骨下動脈起始異常（ALSCA）を伴う症例はの発生頻度 は0.05 0.1\%と非常に稀である。症状の有無や解離の有無により， 開胸による人工血管置換術かステントグラフト内插術（TEVAR） かが選択され，またALSCAの有無によっても治療方針が変わっ てくる。今回我々が経験した右側大動脈弓に伴う KDのタイプ 別治療指針を報告する。

【症例】（1）55歳男性。6 年前発症の B 型慢性解離性大動脈 瘤。嶼下障害を主訴に来院。右側大動脈弓に伴う KD（最大径 $55 \mathrm{~mm}$ ）による食道の圧迫を認め, ALSCA も認めた（Edwards IIIB)。右前外側開胸部分的胸骨切開 (Rt.ALPS) アプローチ による全弓部㧍よび下行置換術を施行。(2) 49歳 男性。健診 で施行した上部消化管内視鏡検查で食道に壁外性圧排所見があ り CT 撮像。右側大動脈弓に伴う KD（最大径 $50 \mathrm{~mm}$ ）を認めた (Edwards IIIA)。無症状のためTEVAR施行。（3）50歳女性。 Marfan 症候群。甲状腺腫瘤の精查でCT 施行。右側大動脈に 伴う KD（最大径 $43 \mathrm{~mm} ） に A L S C A も$ 認めた（Edwards IIIB）。 䓵下時の違和感あり。左総頝動脈 - 左鎖骨下動脈バイパス術と 同時に左鎖骨下動脈塞栓術を施行後, 下行置換術を施行（ハイ ブリッド手術)。

【まとめ】若年者の KDで解離性, また有症状の場合は圧排症状 をとるための確実な瘤切除と人工血管置換を考虑し, 開胸での 手術が優先される。一方無症状でALSCAを伴わない場合には単 純にTEVARでの治療を考慮しうるが,ALSCAを伴う場合には 左鎖骨下動脈へのバイパスとその中枢の閉鎖が必要と考えられ る。また有症状の場合は瘤切除を考慮するが, 深部での ALSCA の再建を回避できるハイブリッド手術も有効な術式であると考 えられた。

Key words : Kommerell diverticulum, Aberrant LSCA 


\section{0-24-1 演題取下げ}

\section{0-24-2 右心不全動物モデルに対する低出力パルス波超 音波治療の有効性と安全性に関する基礎的検討}

${ }^{1}$ 東北大学 循環器内科学, ${ }^{2}$ 東北大学大学院工学研究科 電子工学専攻

$\bigcirc$ 中田貴史 ${ }^{1}$, 進藤智彦 ${ }^{1}$, 門間雄斗 ${ }^{1}$, 一條貞満 ${ }^{1}$, 金井 浩 ${ }^{2}$, 下川宏明 ${ }^{1}$

右心不全は肺高血圧症患者の予後を規定する重要な因子である が，近年では左室収縮能の保たれた心不全や補助人工心臟植え 込み後の患者においても右心不全が予後不良因子として問題と なっている。肺高血圧患者においては右心機能の保持が肺血管 抵抗の低下よりも生命予後の改善に関連するとの報告もあり, 右心不全の治療方法の必要性が高まっている。しかし右心不全 に対する有効な治療法は確立されておらず，左心不全治療薬の 右心不全に対する有効性は示されていない。右心不全のメカニ ズムは不明な点が多く，心筋虚血や代謝の変化等様々な要因が 指摘されている一方で, 血管新生の促進により右心機能の改善 が得られたとの報告もある。近年, 低出力パルス波超音波（lowintensity pulsed ultrasound : LIPUS) が血管新生や抗炎症, 細 胞増殖作用を誘導することが報告され，我々はこのLIPUSを用 いた新たな低侵襲治療の開発を検討している。当研究室では心 筋梗塞や左室肥大の動物モデルにおいてLIPUS照射により血管 新生が促進され，心機能の低下が抑制されることを報告した。 本研究では肺動脈性肺高血圧症モデルであるSugen/Hypoxia ラットと右室圧負荷モデルである肺動脈縮窄マウスの 2 種類の 右心不全動物を用いて実験を行う。Sugen/Hypoxiaラットで LIPUS照射により心エコー, 心臓カテーテル検査，心臓MRI検 査にてコントロール群に比較し有意に右心機能の改善を認め, 組織学的評価においても心筋肥大, 線維化の有意な低下を認め た $(\mathrm{P}<0.05)$ 。肺動脈縮窄マウスにおいても心エコー検查にて右 心機能の改善傾向がみられた。以上から, LIPUS 治療は肺高血 圧による右心不全に対して有効である可能性がある。

Key words : right ventricular failure, low invasive therapy

\section{0-25-1 内シャント再設置術の成績・術式・リスク因子の検討} ${ }^{1}$ 岡山大学大学院医歯薬学総合研究科 心臓血管外科, ${ }^{2}$ 岡 山大学病院 医療安全部, ${ }^{3}$ 岡山大学大学院医歯薬学総合研 究科 $\mathrm{CKD} \cdot \mathrm{CVD}$ 地域連携包括医療学, ${ }^{4}$ 岡山大学大学院 医歯薬学総合研究科 腎·免疫 - 内分泌代謝内科学, ${ }^{5}$ 岡山 大学大学院医歯薬学総合研究科 血液浄化療法人材育成シ ステム開発学

$\bigcirc$ 藤井泰宏 ${ }^{1}$, 大澤 晋 $^{2}$, 内田治仁 ${ }^{3}$, 竹内英実 ${ }^{4}$,

大高 望 ${ }^{5}$, 笠原真悟 ${ }^{1}$

【目的】近年, 透析治療の長期化に伴い, 内シャント手術におけ る内シャント再設置術の割合が増えている。再設置術では血管 の荒廃から手術戦略に難渋する場合も多い。内シャント再設置 術の術式とその開存率について検討した。

【方法】対象は2018年5月1日～2020年4月9日，内シャント設置 術を施行した99例。男性56例。平均年齢73歳 \pm 11 歳（34歳～93
歳)。再設置57例 (57.5\%)。Kaplan-Meier 法で R 群と N 群の開存 率比較を行った。

【成績】患者背景として, 年齢, 3 大成人病保有率, 膠原病, 原 因腎疾患, 抗血小板剂・抗凝固剂使用率, 心不全, ステロイド 使用率，アクティブな喫煙率に両群間に有意差はなかった。 N 群はタバコ窩AVF 13例, 橈骨動脈 AVF 27例, 上腕動脈 AVF 2例であった。 $\mathrm{R}$ 群は，旧シャント同側上肢再設置が34例（橈 骨動脈 24 例，尺骨動脈 1 例，上腕動脈 2 例，AVG1例，その他 6 例), 対側上肢新規設置が 10 例（橈骨動脈 9 例, その他 1 例 $)$, 対 側上肢再設置が13例（橈骨動脈6例, 尺骨動脈 1 例, 上腕動脈 2 例, AVG4例）であった。手術時間はR 群で有意にN群より長かった (54 \pm 13 分 vs $87 \pm 40$ 分, $\mathrm{P}<0.001)$ 。一次開存率（N群 vs R 群； 1ヶ月 $94.2 \%$ vs $91.3 \%, 3$ ケ月 $80.6 \%$ vs $76.6 \% ， 6$ ケ月 $66.7 \% ， 1$ 年 $55.8 \%$ vs $45.8 \%$ ) と二次開存率（1ヶ月 $94.2 \%$ vs $93.6 \%$ ， 3ケ月 $86.4 \%$ vs $80.9 \%$ ，6ケ月 $79.5 \%$ vs $76.1 \% ， 1$ 年 $79.1 \%$ vs $63.7 \%)$ は 有意差を認めなかった。再手術例の50.9\%（29/57）で術後初回 の透析から穿刺可能であった。

【結論】再設置術は, 術式が複雑化し, 手術時間が長くなる傾向 にあった。開存率に有意差は無いが，再手術では若干開存率が 落ちる傾向にあった。

Key words : Vascular Access, Re-operaiton

\section{0-25-2 transposed brachial-basilic arteriovenous fistula (TBBAVF) の経験と早期成績} 兵庫県立淡路医療センター 心臓血管外科 殿城秀斗, 高橋宏明, 後竹康子, 杉本貴樹 当院におけるTBBAVFによるバスキュラーアクセスの経験と早 期成績について，若干の文献的考察を加えて報告する。症例は 2019年 9 月ー2020年 5 月にTBBAVFによるバスキュラーアク セスを作成した 7 例（60-91歳, 平均70歳, 男 : 女 = 3：4）を 対象とした。初回手術例 2 例, 再手術例 5 例で, 全例前腕表在 静脈が不良であった。再手術例では全て元々のバスキュラーア クセス閉塞が主訴で当院受診されており閉塞に対して経皮的カ テーテル治療行っている。TBBAVFは全例一期的に手術してい る。 7 例中 7 例使用可能であった。 1 例で術後 1 日目にシャン トスリル消失あり吻合部血栓認め, 緊急で再吻合を行った。また, 1 例で術後 3 ケ月目に吻合部狭窄を認め経皮的カテーテル治療 を行った。前腕末梢におけるバスキュラーアクセス困難例に対 して, TBBAVFは十分な血流を確保できる自家動静脈のバスキュ ラーアクセスとして有効であると考えられた。

Key words : transposed brachial-basilic, arteriovenous fistula

\section{0-25-3 中心静脈病変によるバスキュラーアクセス関連 静脈高血圧症に対するバイパス術}

関西医科大学総合医療センター 血管外科 ○坂下英樹, 山本暢子, 大野雅人, 北岡由佳, 駒井宏好 【はじめに】血液透析患者における中心静脈の高度狭窄，閉塞： バスキュラーアクセス (VA) 関連静脈高血圧症 (VH) は上肢 の著明な腫脹をきたすだけでなく，透析の際に穿刺困難や，患 側上肢での内シャント作製が困難となるため極めて深刻な合併 
症である。今回, 当院で行った VHに対するバイパス症例を報 告する。

【症例】症例1: 74歳男性, 右前腕に自己血管による内シャント (AVF) があり, 中枢の鎖骨下静脈狭窄に対し5回血管内治療 （PTA）を施行されていたが，鎖骨下静脈閉塞で紹介となった。 対側上肢はスティール症候群で内シャントを閉鎖した既往があっ たため, 外頸静脈をグラフトとして採取し橈側皮静脈から内頸 静脈へバイパスを作製した。症例2: 76歳男性, 左前腕の人工血 管内シャント (AVG) があり, 中枢の鎖骨下静脈狭窄に対し PTAが行われるも再狭窄し紹介となった。対側上肢は表在静脈 がそしく新たな VA 作製も困難と判断し, 腋窩静脈から内頸静 脈へ大伏在静脈を用いてバイパスを作製した。症例3: 52歳男性, 左手関節に AVFが作製されており, 作製後より上肢腫脹が出現 した。シャント造影では鎖骨下静脈閉塞が確認され, PTAも不 成功で, 52 歳という年齢を考慮し現AVFを温存する目的で腋窩 静脈から内頸静脈へ人工血管を用いてバイパスを作製した。3例 とも術後上肢腫脹は軽減した。

【まとめ】VHに対する治療はガイドラインではPTAが第一選択 であり，外科的には現VAを閉鎖して対側に新たな VAを作成す ることが望ましいとされている。しかし透析管理の向上により 長期透析患者が増加してきている昨今では，血管外科的テクニッ クを駆使してVAの温存にあたることが肝要であると考える。

Key words : vascular access, venous hypertension

\section{0-25-4 緊急VAIVTの成績}

埼玉県済生会川口総合病院 血管外科

$\bigcirc$ 村井則之, 高坂彩子, 向後寛子

【目的】vascular access（VA）は透析治療を受け続けるため非 常に重要である。透析困難の際, VA は緊急で修復されるべきで あり, vascular access intervention therapy（VAIVT）は有効 な治療手段である。今回, 緊急VAIVTの短期・長期成績につい て検討した。

【方法】 2009 年 10 月 1 日から 2020 年 3 月 31 日の期 間に緊急VAIVTを施行した 645 例を施行したが， 3 年間追 跡したできた症例を対象とし, 重複する症例を除き, そして明 確な緊急対象とするため完全閉塞していたarteriovenous fistula (AVF) 116 例を対象に検討した。平均年齢は67.9歳（36 - 93 歳), 男性 81 例, 糖尿病合併 63 例であった。

【成績】112 例に血流再開ができ, 血流再開を初期成功とする ならば初期成功は $96.6 \%$ であった。1 ケ月上透析に仕様 可能であったのは 97 例, $83.6 \%$ 。 3 年以上使用あるいは 悪性疾患等による死亡まで使用可能であった長期開在は 66 例, $56.9 \%$ であり, 最大 110 ケ月の開在例を確認した。長期開 在した症例で追加のVAIVTを行わなかったのは 12 例のみで, 108 ケ月の開在期間に合計 16 回のVAIVTを行った症例も あった。

【考察】VAIVTはVA維持のため有用であるとされているが, 完全閉塞への緊急対応でも血栓吸引と閉塞原因となった狭窄を 一期的に解除することが可能で，有用であると考えられた。一方， 今回の対象期間中ではないが, 静脈損傷にて皮下出血が重篤に
なり, 末梢神経障害を併発した症例もあり, 治療は慎重である ベきことも留意すべきである。

【結論】緊急VAIVTは有用である。

Key words : VAIVT, VA

\section{0-25-5 長期開存を目指したブラッドアクセス管理にお ける他職種との連携}

JCHO 南海医療センター

$\bigcirc$ 岩田英理子, 小寺愛子

当院は大分県で2番目に多い透析患者数を有しており, 且つ他施 設の困難なブラッドアクセス手術も受け入れている。医師, 穿 刺等に関わるメディカルスタッフ, 院外医療機関との連携によ り地域全体のブラッドアクセスの開存性の向上を目指している。 当院は160名以上の外来透析患者がおり, 医師は透析科 1 , 泌尿 器科 3 , 心臟血管外科 2 がブラッドアクセス管理に携わっている。 当科は経皮的シャント拡張術（VAIVT）や他科にて作成困難な 症例の外科手術を担当している。以前はシャント閉塞の原因が 不明のまま紹介されることも多く，また手術時に心機能評価が されていないことも多かった。従来の胸写・心電図の他, 心工 コー, CT等も定期検査として組み込んだ。穿刺に携わる臨床工 学技士の意識改革と実力向上のため, 流量の異常時, 音の変化 時などに血管エコーを積極的に行い, トラブルが脱血あるいは 返血側の問題か, 脱血不良をきたす内径, 再循環が起こる流量 などを個々に評価し, 各患者別に当科に紹介するタイミングを 指導した。閉塞したとしても，シャントの評価を前もって行う ことにより閉塞の原因がシャントによるものか血圧低下など全 身状態によるものかの見極めもより的確に行えることをめざした。 さらに, 各施設の穿刺を含めた管理能力に応じてシャントを選 択している。VAIVT, 外科手術も泌尿器科医師の技量により変 動があるが, 当科への紹介はここ 5 年でVAIVTは $2 / 3$, 外科的手 術は $1 / 2$ 程度に減少傾向にある。他施設の穿刺困難例については 技師が他施設の技師への実技指導まで行っている。メディカル スタッフ全体の技術の向上がシャントのより長期の開存を維持 できると考える。

Key words : blood access, team medical care

\section{0-26-1 孤立性上腸間膜動脈解離の遠隔期成績}

弘前大学大学院医学研究科 胸部心臓血管外科

$\bigcirc$ 在強, 近藤慎浩, 齊藤良明, 皆川正仁, 大徳和之 背景: 大動脈解離を伴わない孤立性上腸間膜動脈解離は比較的 稀な疾患とされていたが, 画像診断の向上により診断される症 例が増えている。治療の選択肢としては保存的治療を主体とし て開腹による血行再建，血管内治療と多岐にわたっておるが, 治療法選択に苦慮しているのが現状である。目的:これまでに 当院での治療を受けた孤立性上腸間膜動脈解離の患者の遠隔期 成績を明らかにし, 発症時に選択した治療法の妥当性を検討す る。方法: 2010年1月から 2020 年3月までに当科で経験した孤立

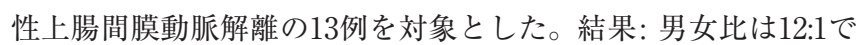
あり, 年齢は35-76（平均54.7）歳であった。全例造影 $\mathrm{CT}$ 検査で 確定診断を得た。治療は発症時から11例には絶食安静による保 
存的治療を行い軽快した。腸管虚血が疑われたSakamoto ら分類 Type IIの1例に血管造影を行ったが追加治療は行わず保存的治 療を行った。食後腹痛を感じた 1 例は上腸間膜動脈真腔狭窄を 認め、ヘパリン持続投与を行い軽快した。鎮痛剂無効であった Type IIIの1例に対しては大伏在静脈を用いた右外腸骨動脈一上 腸間膜動脈バイパス術を行った。腸壊死に至った症例は無かった。 平均 $6.67 \pm 2.83$ 年の観察期間において全例生存しており再入院や 追加治療を必要とした症例は無かった。フォローアップCTでは 2例に血栓化偽腔の消失が得られ，1例は解離腔の増大がみられ る他は著変なく経過している。結論: 孤立性上腸間膜動脈解離の 多くは保存的治療が可能であり，遠隔期にも外科的治療介入を 要する可能性は低いと考えられた。ただし，解離の形態は造影 CTで定期的に評価する必要があると考えられた。

Key words : Isolated SMA dissection, Conservasal treatment

\section{0-26-2 孤立性腹腔動脈解離・上腸間膜動脈解離 19 例 の治療戦略と長期遠隔成績}

${ }^{1}$ 横浜市立市民病院 心臓血管外科, ${ }^{2}$ 横浜市立大学 外科 治療学 心臟血管外科

$\bigcirc$ 富田啓人 ${ }^{1}$, 浦中康子 ${ }^{1}$ ，笠間啓一郎 ${ }^{1}$, 益田宗孝 ${ }^{2}$

【背景】孤立性内臓動脈解離は比較的稀な疾患であるが,近年は 画像診断能の向上により遭遇することが増えている。我々は当 院で孤立性腹腔動脈解離・上腸間膜動脈解離19例を経験したの で,臨床像や長期遠隔成績について検討し報告する。

【対象】2008年1月より2018年8月までに孤立性腹腔動脈解離・上 腸間膜動脈解離と診断された症例19例を臨床像・長期遠隔成績 について後ろ向きに検討した。

【結果】男性16例,女性3例, 平均年齢54.7歳（38～89歳）,腹坨動 脈解離7例,上腸間膜動脈解離11例, 両者の合併が1例であった。 初発症状は腹痛 10 例, 心窩部痛 6 例, 腰背部痛 3 例, 下血1例であっ た。3例は無症状であり by chanceでCTにて診断された。発症 時の解離形態は,偽腔開存型9例,偽腔閉塞型10例であった。無症 状の症例は偽脘開存型2例,血栓閉塞型1例であった。無症状の症 例を除く 16 例は入院加療を行った。平均絶食期間は4.5日,抗凝固 療法を 8 例に行った。平均入院期間は 13.9 日であり, 全症例保存的 加療で軽快退院した。平均追跡期間は5.1年（1.6〜10.9年）であ り,CTにて画像評価を行った。追跡期間中に偽腔開存 9 例中 3 例, 偽腔閉塞10例中8例に偽腔の縮小を認めた。縮小した偽腔開存3 例は偽腔が血栓化した部位が縮小した。縮小した偽腔閉塞8例中 5 例がULPのみ残存し小動脈瘤の形態を呈し,その後 2 例は遠隔期 に小動脈瘤も消失した。

【考察】本検討では経時的な血管形態の様々な変化を認めたが, 全症例で侵襲的治療を行わず,保存的治療で良好な経過を得るこ とができた。しかしながら腸管虚血, 瘤拡大の為, 侵襲的治療が 必要となった症例報告もあり, 慎重な加療及びフォローが必要と 考えられる。

Key words : isolated dissection, visceral arteries

\section{0-26-3 急性腹症で入院した孤立性腹部動脈解離例の臨 床的特徵と予後}

神戸市立医療センター 中央市民病院 循環器内科 $\bigcirc$ 多本慧子, 加地修一郎, 北井 豪, 江原夏彦, 木下 愼, 古川 裕

【背景】孤立性腹部動脈解離はしばしば急性腹症を伴い, 緊急入 院を必要とするが，臨床経過はよく分かっていない。

【方法】対象は2009年から2020年の期間に当院で上腸間膜動脈解 離あるいは腹腔動脈解離と診断され，症状を伴った54例。39例 が上腸間膜動脈解離 (SMA 群)，15 例が腹䏶動脈解離（CA 群） であり，臨床経過を比較検討した。

【結果】発症時の平均年齢は両群で差を認めなかった（SMA群 $54 \pm 9, \mathrm{CA}$ 群 $51 \pm 10, \mathrm{P}=0.30)$ 。両群とも大半を男性が占めた (SMA 群35例 $(90 \%), \mathrm{CA}$ 群14例 $(93 \%), \mathrm{P}=0.68)$ 。入院中 に約 $2 / 3$ 症例で CRPの上昇が認められたが, 最大 CRP 值は両 群間で差がなかった（SMA群 $1.1 \pm 1.1 \mathrm{mg} / \mathrm{dL}, \mathrm{CA}$ 群 $1.9 \pm 2.2$ $\mathrm{mg} / \mathrm{dL}, \mathrm{P}=0.22)$ 。発症当日に症状が軽快した例は両群共に70 \%を越えた（SMA群28例（72％）, CA 群 11例（73\%）, P= 0.91)。症状の持続期間は平均でSMA群 $2.0 \pm 2.4$ 日, CA 群 1.7 \pm 1.5 日（P=0.78）であった。平均 $29 \pm 27$ 月の追跡期間中に死 亡や, 解離後の合併症に対する外科手術を両群とも認めなかった。 上腸間膜動脈解離のうち1人のみ, 解離後の狭窄による腹部症状 を認めて，血管内治療を必要とした。発症時の症状が軽快した 後に症状の再発を認めたものは4例（7％）のみ（SMA群4例（10 \%)，CA群0例（0％）, P=0.20）であった。また退院時にアス ピリンを処方された 11 例中 1 例 $(9 \%)$ に症状再発を認め, 処方 されなかった 43 例中 3 例 $(7 \%$ ）に症状再発を認めたが, 再発率 は両群間で有意差を認めなかった $(\mathrm{P}=0.88)$ 。

【結論】急性腹症で発症した孤立性腹部大動脈解離例においては, 上腸間膜動脈解離例と腹腔動脈解離例ともに発症後速やかに症 状の消失を認め, 保存的加療にて安定した経過を辿った。

Key words : visceral artery dissection, superior mesenteric artery

\section{0-26-4 孤発性特発性腹腔動脈解離により形成された解 離性脾動脈瘤を契機に消化管出血を発症し、治療介入を要 した 2 症例}

${ }^{1}$ 東京大学 大腸肛門 - 血管外科, ${ }^{2}$ 静岡県立総合病院 消 化器外科, ${ }^{3}$ 静岡県立総合病院 病理学部

○松原和英 ${ }^{1}$, 松倉 満 $^{1}$, 赤井隆文 ${ }^{1}$, 伊佐治寿彦 ${ }^{1}$, 高山利夫 ${ }^{1}$, 保科克行 ${ }^{1}$, 金本秀行 ${ }^{2}$, 村松 彩 $^{3}$

【背景】孤発性特発性腹腔動脈解離は稀な疾患であり, 解離が 脾動脈瘤に及んで仮性脾動脈瘤を形成することがある。破裂り スクは少ないとされており，経過観察を選択されることが多い。 Hemosuccus Pancreaticus（HP）は消化管出血を来す稀な疾患 であり，慢性膵炎を背景とした脾動脈瘤や仮性囊胞から膵管経 由でVater乳頭より出血を起こす病態である。今回, 孤発性特 発性腹腔動脈解離により解離性脾動脈瘤を形成し, HP 発症を契 機に治療介入を行なった 2 症例を経験したので報告する。

【症例 1】62 歳男性。高血圧で内服加療中であった。腹痛と下 
血を主訴に受診し, 採血でアミラーゼ上昇と貧血, CT T゙腹腔動 脈解離と解離性脾動脈瘤を認めた。内視鏡で出血源は特定出来 なかったが, ERCPで膵管と脾動脈瘤の交通が確認され，HP 診断した。腹垫鏡下膵体尾部切除を施行し, 症状再発なく経過 している。

【症例 2】49歳男性。既往特になし。腹痛と吐下血を主訴に受 診し, 採血でアミラーゼ上昇と貧血, CTで腹腔動脈解離と解 離性脾動脈瘤を認めた。内視鏡で出血源を特定出来なかったが, 臨床的にHP と診断し, 経皮的に脾動脈瘤塞栓術を施行した。術 後消化管出血の再燃は認めていない。

【結論】特発性孤発性腹腔動脈解離により形成された解離性脾動 脈瘤を契機に消化管出血を発症し，治療介入を要した 2 症例を 経験した。解離性脾動脈瘤を認める患者では消化管出血を起こ すことがあり, 内視鏡で出血源不明の場合はHPを疑って積極的 な治療介入が必要と考えられた。

Key words : splenic artery dissection, hemosuccus pancreaticus

\section{0-26-5 外科的血行再建を要した内蔵動眽瘤}

市立四日市病院

$\bigcirc$ 野田裕俊, 服部圭祐

内臟動脈瘤は臨床上しばしば経験する疾患である。近年検診や 他疾患の精査などでCTを受ける機会も増加し，偶然発見される 症例も多く認める。また血管内治療の発展に伴いコイル塞栓や ステントグラフトによる手技も増加しているが, 内臓虚血が懸 念される症例は外科的血行再建が必要である。今回我々は外科 的血行再建を要した2症例を経験したためこれを報告する。2015 年1月から 2020 年 4 月まで外傷を除く当院で治療を要した内臓動 脈瘤を26例経験し, コイル塞栓を 24 例, 外科的血行再建を 2 例に 施行した。2症例は以下の通りである。症例 $1 ： 70$ 歳男性, 急性 腹症のスクリーニング CTで総肝動脈瘤を指摘されたため当科を 紹介された。造影 CT で多発内臓動脈瘤（総肝動脈 $36 * 57 \mathrm{~mm}$ の 他, 腹腔動脈 $13 \mathrm{~mm}$, 固有肝動脈 $15 \mathrm{~mm}$ など）を認めたが, 総肝 動脈のみ手術適応と判断した。総肝動脈は起始部から胃十二指 腸動脈分岐部直前まで囊状に瘤化しており，十分に耐術可能と 判断したため開腹血行再建を選択した。自科静脈再建を予定し ていたが直接吻合できた。病理組織は阽状硬化に伴う変化の所 見であった。術後経過は良好で9日目に退院された。症例 $2: 44$ 歳女性, 検診エコーで膵頭部腫瘤を指摘され, CTで腹腔動脈瘤 と診断されたため当科を紹介された。既往なし。造影 CTで左胃 動脈分岐直後に $42 * 37 \mathrm{~mm}$ の襄状瘤を認めた。若年であることか ら開腹血行再建を選択した。右胃動脈は温存し, 腹腔動脈と脾 動脈を吻合し, 総肝動脈は結紮した。病理組織は分節性動脈中 膜融解を疑う所見であった。術後経過は良好で術後5日目に退院 された。文献的考察を加えこれを報告する。

Key words : aneurysm, surgical revascularization

\section{0-26-6 肝動脈瘤に対して外科的治療を施行した 3 症例 の検討}

JA 北海道厚生連 札幌厚生病院 心臓血管外科

○高橋一輝, 奥田紘子, 内田 恒, 吉田博希

肝動脈瘤は内臓動脈瘤の $20 \%$ 占め比較的稀な疾患であるが, 破裂すると高率に致死的となるため，破裂する前に治療を行う 必要がある。今回我々は外科的治療を行った 3 例の未破裂肝動脈 瘤を経験したので若干の文献的考察を加えて報告する。1症例は 59 歳女性で $29 \mathrm{~mm}$ の総肝動脈瘤に対して瘤切除を行い, 大伏在 静脈を用いて置換術を行った。2症例は62歳男性で膵癌に対して 膵頭十二指腸切除施行の際に $8 \mathrm{~mm}$ の総肝動脈に対して, 術後の 膵液ろうを考慮し, 瘤壁の縫縮術を施行した。3症例は54歳男性 で $16 \mathrm{~mm}$ の固有肝動脈瘤に対して瘤切除と大伏在静脈を用いた バイパス術を行った。それぞれ術後 9 年, 4 カ月, 2 ケ月と問題なく 経過している。肝動脈瘤に対する治療としては血管内治療も多 く報告されており，良好な結果が得られているが，外科的治療 か血管内治療のどちらを行うかは患者の状態と動脈瘤の解剖学 的位置形態により決定される。今回の3症例に関しては若年であ ること, 動脈瘤の解剖学的位置形態を考慮し外科的治療を選択 した。外科的血行再建に関しては静脈グラフトを用いることで 術後長期開存を得ることが出来ており, 血行再建法として適切 であると考えられた。肝動脈瘤の外科的治療法には瘤切除術・ 綘縮術・空置術などがあり，血行再建法には端々吻合・置換術・ バイパス術などがあるが, 解剖学的な局在を考慮し, これらを 適切に選択して治療することが重要である。

Key words : Hepatic aneurysm, Peripheral aneurysm 